\title{
PONTO-CASPIAN AND MEDITERRANEAN \\ FAUNAL AND FLORAL RECORDS OF UPPER PLEISTOCENE-HOLOCENE SEDIMENTS FROM THE IZMIT GULF (MARMARA SEA, TURKEY)
}

\author{
Elmas Kırcı-Elmas ${ }^{1}$, Atike Nazik²*, Sevinç Kapan ${ }^{3}$, Engin Meriç${ }^{4}$, Emine Şeker Zor², Beste Kalkan², \\ Tamer Doğan ${ }^{5}$ \& Ayşegül Güney ${ }^{6}$
}

Received: 2 December 2020 / Accepted: 1 April 2021 / Published online: 8 April 2021

\begin{abstract}
Gulf is located between Kocaeli and Armutlu peninsulas at east of Marmara Sea and the interaction area of North Anatolian Fault Zone (NAFZ) and Marmara Graben systems. In this study, the faunal and floral contents (ostracod, foraminifer, mollusc and diatom) of the samples belonging to seven drilling cores were studied and obtained the radiocarbon and optically stimulated luminescence (OSL) age data in order to establish on the Black Sea - Marmara Sea - Mediterranean water connections and palaeoenvironmental changes.

The sediments in this study are Late Pleistocene-Holocene aged and only cover the Marine Isotope Stages MIS-5 (interglacial), MIS-3 (an interstadial period between MIS-4 and MIS-2 glacial epochs) and MIS-1. The determination of ostracod and mollusc fauna of the Mediterranean and Ponto-Caspian origin provide important clues to water exchange between the Mediterranean and the Black Sea. Although some Mediterranean originated ostracods occur sporadically with low abundance, absence of foraminiferal fauna and existence of Ponto-Caspian ostracods together with fresh water and cosmopolitan diatom flora indicate that the area strongly interacted with the Black Sea waters during MIS-5. The faunal and floral characteristics of the sediments deposited during MIS-3, clearly denote that the Izmit Gulf was connected with the Black Sea and the Mediterranean Sea at the beginning of MIS-3 (ca. $52.0-40.0 \mathrm{ky}$ BP) and the shallow shelf areas were frequently affected by both the Black Sea discharge and Mediterranean input. A thick Holocene sedimentary sequence recovered from the southern Hersek Burnu drilling cores reflects the environmental changes after the latest Black-Mediterranean seas connection.

The studied ostracod and mollusc assemblages are mainly characterized by the Mediterranean originated species with a few relict Ponto-Caspian fauna. Also, the benthic foraminiferal assemblages are dominated by normal marine and euryhaline species, reflecting the salinity fluctuations in the Holocene interval.
\end{abstract}

Keywords: Foraminifera, ostracod, mollusc, diatom, palaeoenvironment, marine isotope stage, NW Turkey

\section{INTRODUCTION}

The Quaternary Period containing a series of cold and intervening warm phases (glacials/interglacials) caused sea level variations and drastic environmental changes. Upper Pleistocene stage (126.0-11.7 ky) is characterized by Riss-Würm/Eemian interglacial and Würm/Weichselian glacial episodes. Global to regional climatic and hydrological changes initiated in the surrounding Mediterranean and Ponto-Caspian basins during the glacial and interglacial periods constitute the Quaternary palaeoceanographic evolution of the Marmara Sea (e.g., Stanley and Blanpied, 1980; Aksu et al., 2002; Badertscher et al., 2011; Sorokin, 2011; Yanina, 2014). İzmit Gulf constitutes the most eastern part of the Marmara Sea (Fig. 1) which is a small intercontinental basin connected to the Mediterranean and the Black Sea and the western part of active North Anatolian Fault Zone (Ketin, 1948, Aksu et al., 2002; Vardar et al., 2014). It is an eastwest elongated depression with a $55 \mathrm{~km}$ length and 2-10 $\mathrm{km}$ width. Along W-E axis, the İzmit Gulf comprises three connected sub-basins namely western (Darica), Central (Karamürsel) and Eastern (Gölcük) separated by sills at $\sim 55 \mathrm{~m}$ and $38 \mathrm{~m}$ water depths (Çağatay et al., 2003; Kurt and Yücesoy, 2009). The Central Basin is the largest and deepest with a maximum water depth of around $200 \mathrm{~m}$. The İzmit Gulf has a permanent two-layered water system as an extension of the Marmara Sea. The brackish Black Sea water $(18 \%$ ) flowing through the İstanbul Strait (Bosphorus) constitutes the upper water layer. The lower water layer originates from the high salinity Mediterranean waters $(39 \%$ ) inflowing to the Marmara Sea via the Çanakkale Strait (Dardanelles) (Ünlüata et al., 1990; Beşiktepe et al., 1994).

Important geological investigations in the Izmit Gulf and its vicinity have been carried out since 1950's (Pfannenstiel, 1944; Ardel and İnandık, 1957). Marmara Sea, a waterway between the Mediterranean and the Black Sea, has been affected by the changing sea levels during Quaternary. Recent studies have focused on the relations between the Marmara Sea and the Black Sea and their evolution during the Quaternary. Meriç (1995a) conducted a pioneering study that documented Quaternary sequence of the İzmit Bay between Hersek and Kaba Burun in detail. Meriç (1995b) point out a water-way connection between the Marmara and Black Sea by İzmit-Sapanca and Sakarya

\footnotetext{
${ }^{1}$ Department of Marine Geology and Geophysics, Institute of Marine Sciences and Management, Istanbul University, İstanbul, Turkey.

${ }^{2}$ Department of Geological Engineering, Faculty of Engineering, Çukurova University, Adana, Turkey, email: anazik@cu.edu.tr

${ }^{3}$ Department of Geological Engineering, Faculty of Engineering, Çanakkale Onsekiz Mart University, Çanakkale, Turkey.

${ }^{4}$ Moda Hüseyin Bey Sokak No: 15/4, Kadiköy, İstanbul, Turkey.

${ }^{5}$ Department of Computer Technologies, Vocational School of İmamoğlu, Cukurova University, Adana, Turkey.

${ }^{6}$ Department of Geological Engineering, Faculty of Engineering, Aksaray University, Aksaray, Turkey.
} 


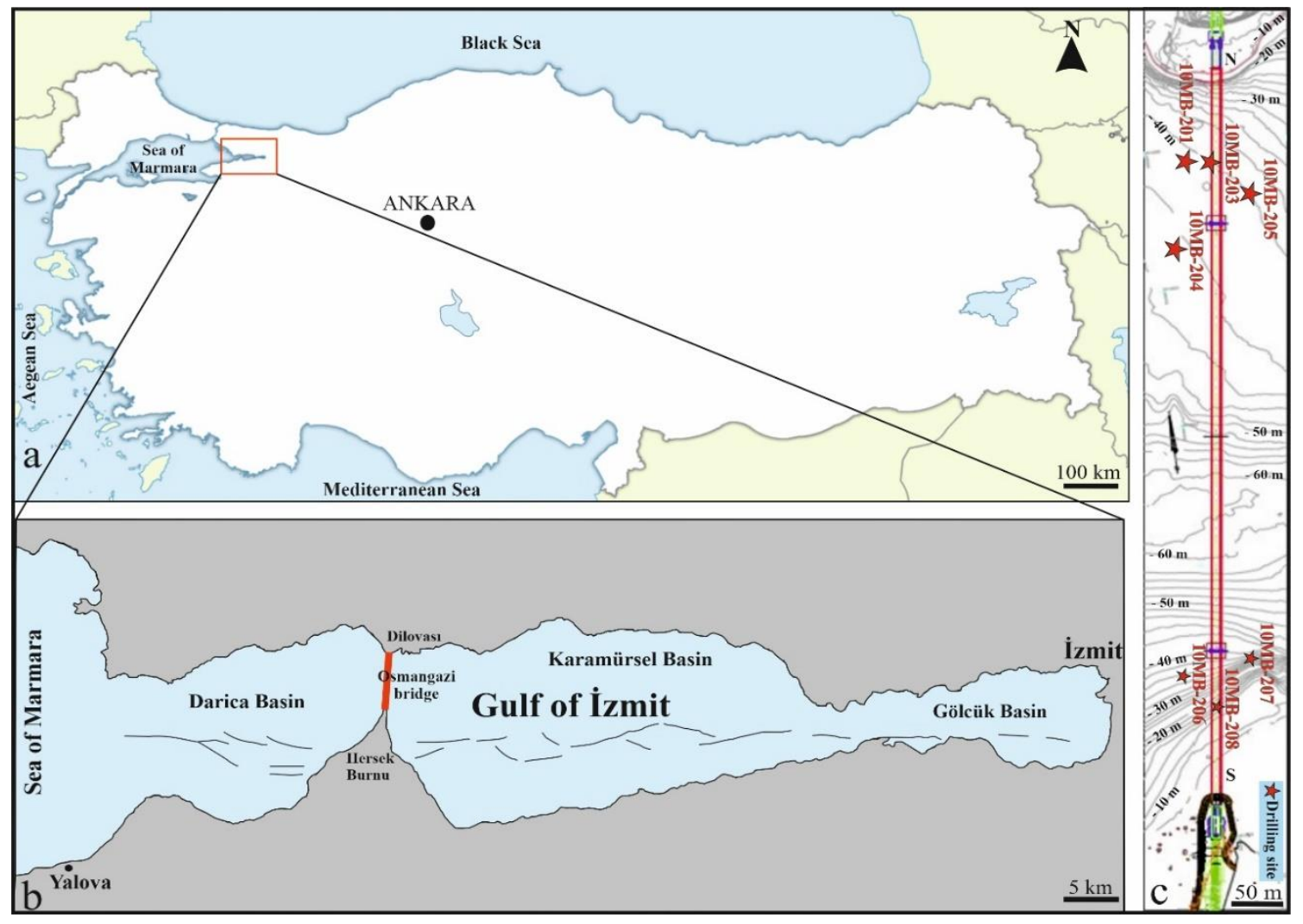

Fig. 1 Location map. a. Turkey map, b. Gulf of İzmit and Osmangazi Bridge Route, c. Locations and numbers of drillings.

valleys before of the existence of Bosphorus, Major et al. (2002) studied the Marmara and Black Sea connections during the periods between Late Glacial and Interglacial by using sedimentological and radiometric methods. Some researhers studied the connection of the Marmara and Black Sea by the way the İznik Lake (Meriç et al., 2009; Nazik et al., 2011; 2012; Meriç et al., 2018). Taviani et al. 2014 emphasized that the Marmara Sea is a lake connected to the Black Sea from time to time according to their studies performed in the Gemlik Gulf. Badertscher et al. (2011) indicate that 12 times Mediterranean intrusions have been carried out to the Black Sea since $670 \mathrm{ky} \mathrm{BP}$. The latest lake stage of the Marmara Sea during Marine Isotop Stage 2 (MIS-2). Black Sea-Mediterranean connection with the İstanbul Strait-Marmara SeaÇanakkale Strait during MIS-1 has been studied in detail by many authors (e.g., Stanley and Blanpied, 1980; Ryan et al., 1997; Çağatay et al., 2000; Aksu et al., 2002; Sperling et al., 2003; Kurc1-Elmas et al., 2008; McHugh et al., 2008; Vidal et al., 2010; Eriş et al., 2011; Ivanova et al., 2015; Büyükmeriç, 2016). However, our knowledge of water-exchange events before Holocene in this region is still limited and controversial.

The evidence on the basis of the deposition of sapropel of sediments recovered from the Marmara Sea's Central Basin (Aksu et al., 2002; Tolun et al., 2002), a raised marine terrace from the southwestern Marmara Sea (Yaltırak et al., 2002) as well as marine deposits dated at ca. $36 \mathrm{ky} \mathrm{BP}$ on the southern coast of the İzmit Gulf
(Çağatay et al., 2003) suggest that the Marmara basin was linked to the Mediterranean Sea during MIS-3 period. Later, Çağatay et al. (2009) denote that the Marmara Sea isolated from the Mediterranean Sea from early MIS-4 to early MIS-1. In the Black Sea, MIS-3 corresponds to a highstand (The Surozh transgression), with water level 25 $\mathrm{m}$ lower than today (Yanina, 2014).

In this study, the faunal and floral contents (ostracods, foraminifera, molluscs and diatoms) and the numerical (radiocarbon and OSL) age (Fig. 2) data of drilling samples collected from the İzmit Gulf have been studied in detail in order to understand the water connections among the Black Sea - Marmara Sea - Mediterranean and their palaeoenvironmental changes.

\section{MATERIALS AND METHODS}

In 2010, a series of submarine drilling was carried out during the construction of a suspension bridge (Osmangazi Bridge) in the İzmit Gulf (Fig. 1 and Table 1). The material consisted of 73 sediment samples retrieved from seven drilling cores. The samples were collected at different intervals of the drilling cores (1-108 $\mathrm{m}$ in 10MB-201, 16.5$147 \mathrm{~m}$ in $10 \mathrm{MB}-203,2-69 \mathrm{~m}$ in 10MB-204, $1.5-30 \mathrm{~m}$ in 10MB-205, 4.5-63 m in 10MB-206, 1-43 $\mathrm{m}$ in 10MB-207 and $1-37.5 \mathrm{~m}$ in 10MB-208). 
Table 1 Location, water depth and sediment thickness of drillings

\begin{tabular}{|c|c|c|c|c|c|c|}
\hline Exploration & $\begin{array}{l}\text { Completion } \\
\text { Depth (m) }\end{array}$ & $\begin{array}{l}\text { Mudline } \\
\text { Elevation } \\
(\mathbf{m})^{1}\end{array}$ & $\begin{array}{l}\text { UTM, Zone } \\
\text { 35N Easting }\end{array}$ & $\begin{array}{lr}\text { UTM, } & \text { Zone } \\
\text { 35N } & \text { North- } \\
\text { ing }^{2} & \end{array}$ & $\begin{array}{l}\text { Project Co- } \\
\text { ordinates } \\
\text { Easting }^{3}\end{array}$ & $\begin{array}{l}\text { Project Co- } \\
\text { ordinates } \\
\text { Northing }^{3}\end{array}$ \\
\hline 10MB-201 & 121 & -40.4 & 712359.5 & 4515452.1 & 459125.3 & 4514325.3 \\
\hline 10MB-203 & 161 & -39.7 & 712459 & 4515342.3 & 459220.9 & 4514212.1 \\
\hline 10MB-204 & 120 & -42.1 & 712340.6 & 4515253 & 459099.6 & 4514127 \\
\hline 10MB-205 & 117.2 & -40.1 & 712539.6 & 4515233.4 & 459297.8 & 4514100.5 \\
\hline 10MB-206 & 122 & -35.0 & 712198.8 & 4513759.6 & 458906.8 & 4512639.4 \\
\hline 10MB-207 & 120.9 & -23.2 & 712397.2 & 4513740.4 & 459104.5 & 4512613.4 \\
\hline 10MB-208 & 200 & -18.3 & 712288.5 & 4513650.1 & 458992.8 & 4512526.9 \\
\hline \multicolumn{7}{|c|}{${ }^{1}$ Elevation is based on TUDKA, meters } \\
\hline
\end{tabular}

The drillings were made about $40 \mathrm{~m}$ of water depth in the northern part of the bridge in Dilovas1 region (10MB-201, 203, 204 and 205 ) and about 18-35 m water depths in the southern part of the bridge in Hersek region (10MB-206, 207 and 208). The lithology of the core sediments (Fig. 3) consists mainly of fine to coarse sand with shell fragments, brownish-green colored hard mud with interfingering sand and gravel and homogeneous, plastic, greenish mud. Large mollusc shells are also observed at different levels of drillings.

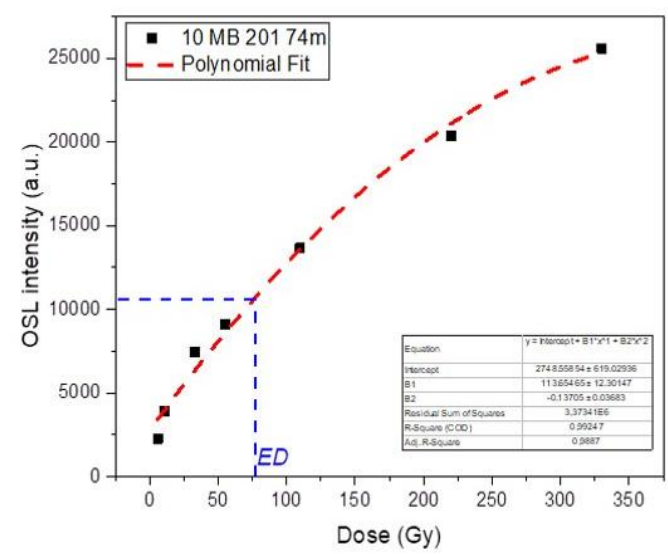

Fig. 2 Growth curve used in determination of ED for sample 10MB-201 $74 \mathrm{~m}$ by using regenerative procedure.

\section{Sample Preparation for fauna and flora}

For faunal analyzes (foraminifera, ostracods, bivalvs and gastropods) and determination of grain-size distributions, sediment samples were dried in an oven at $45^{\circ} \mathrm{C} .10 \mathrm{~g}$ subsamples of dry sediment were moistened with tap water for ca. 24 hours and washed to pass a $63 \mu \mathrm{m}$ sieve. These residues were dried and weighed again. The ratio between the initial subsample and residue weight was used as a measure of the sand content of the sediment. Residues (>63 $\mu \mathrm{m}$ ) were analyzed using a stereomicroscope. Ostracods and molluscs were examined from $>125 \mu \mathrm{m}$ fraction. The descriptions and counts of foraminifera were performed on $>63 \mu \mathrm{m}$ fraction. Where foraminiferal fauna was abundant, the $>63 \mu \mathrm{m}$ fraction was separated into equal aliquots with a microsplitter until an aliquot containing at least 300 specimens was obtained. In low density samples, the whole $>63 \mu \mathrm{m}$ fraction was analyzed. Foraminifera taxa identifications were made based on Yanko and Troitskaja (1987), Yanko (1989), Cimerman and Langer (1991), Sgarrella and Moncharmont-Zei (1993), Kaminski et al. (2002) and Meriç et al. (2004). Taxonomic concepts of Van Morkhoven (1963), Hartmann and Puri (1974), Bonaduce et al. (1975), Breman (1975), Olteanu (1978), Yassinsi (1979), Guillaume et al. (1985), Athersuch et al. (1989), Zangger and Malz (1989), Tunoğlu (1999, 2002, 2003), Boomer et al. (2005, 2010), Mostafawi and Matzke-Karasz (2006), Joachim and Langer (2008), Oprenau (2008), Schornikov (2011), Briceag et al. (2012), Zenina et al. (2017), Javadova (2019) and "MarBEF Data System" (http://www.marbef.org/data/) were followed for identifications of ostracods. Determinations of mollusc species were made by using the studies of Neveskaja (1963), Poppe and Goto (1991, 1993), Çetin et al. (1995), Kapan Yeşilyurt (1997), İslamoğlu and Tchepaliga (1998), Kerey et al. (2004), Meriç et al. (2000, 2005). Selected specimens of foraminifera and ostracod species were photographed using a Quorum (Q150R ES) and Quanta 650 Field Emission scanning electron micrographs at the Central Research Laboratory of Çukurova University (ÇÜMERLAB).

Diatom examination was performed on three samples collected from at $143.5 \mathrm{~m}, 140 \mathrm{~m}$ and $95 \mathrm{~m}$ of drilling 10MB-203. Sediment samples for diatoms analyzes were cleaned with $10 \% \mathrm{HCl}$ and then fixed onto a lam by entellan and a lamella. Diatom flora was identified and photographed under Leica DM $2500 \mathrm{P}$ polarizing microscope at the Geological Enginering Laboratory of the Aksaray University. The taxonomic descriptions and ecological features of the taxa were performed using 


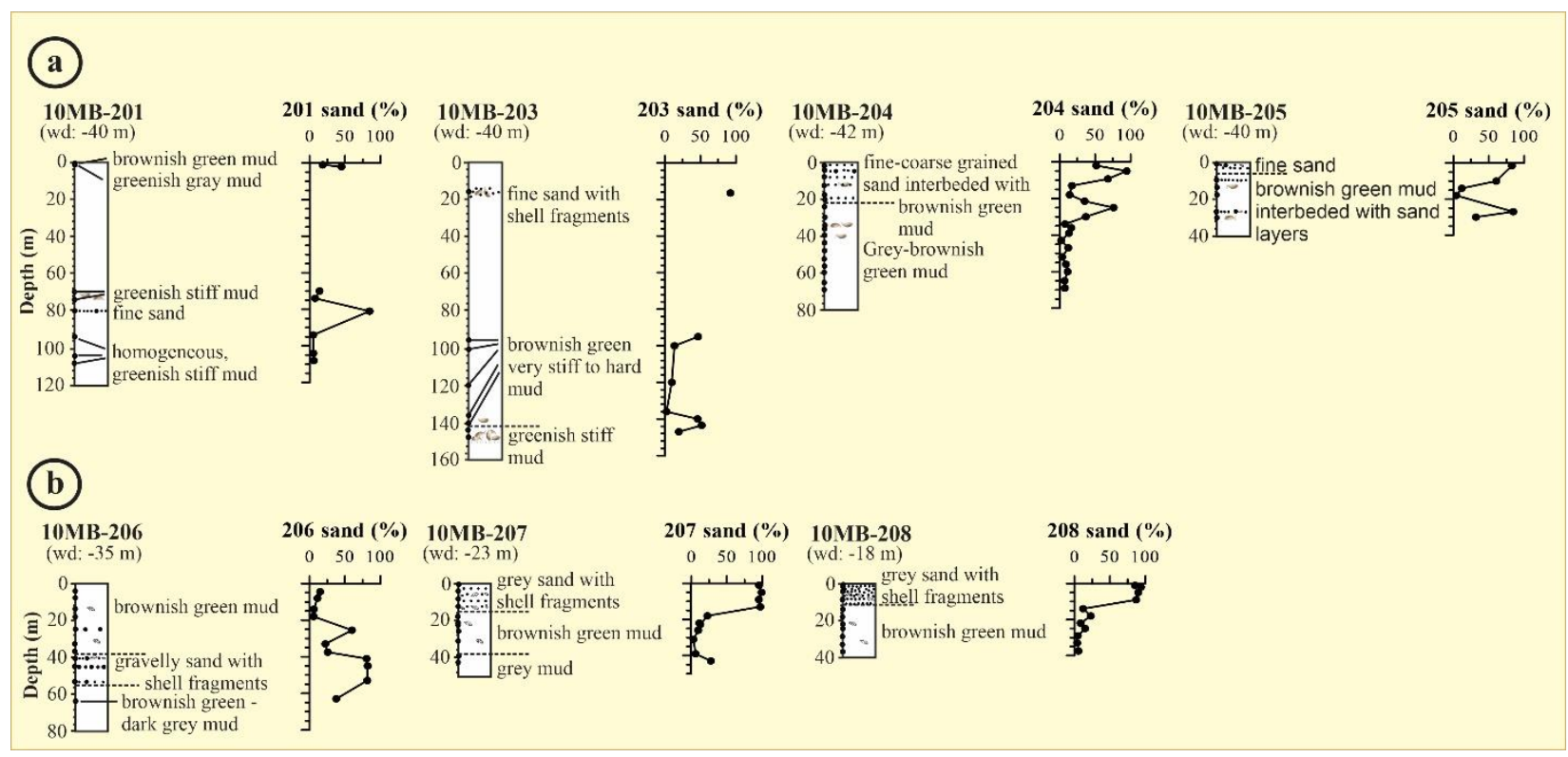

Fig. 3 Lithological features and sand distributions of collected sediment samples a. Dilovas1, b. Hersek Burnu. The lower intervals of drillings 10MB-204 (120-80 m), 10MB-205 (117.2-40 m), 10MB-206 (122-80 m), 10MB-207 (120.9-50 m) and 10MB-208 (200$40 \mathrm{~m})$ are not shown due to absence of sample.

studies of Wetzel (1983), Round (1956, 1984), Krammer and Lange-Bertalot (1986a, 1986b, 1988, 1991), Van Dam et al. (1994), Trojanowski et al. (2001), Pala (Toprak) and Çağlar (2006), Round et al. (2007), Taş and Gönülol (2007), Zaim (2007), Sivaci et al. (2007, 2008, 2013), Kistenich et al. (2014), Varol and Şen (2014), URL-1 - 11.

\section{Radiocarbon Dating}

Conventional radiocarbon dates $\left({ }^{14} \mathrm{C}\right)$ were performed at the Poznan Radiocarbon Laboratory, Poland and Earth and Marine Sciences Institute of TÜBITTAK Marmara Research Center, Turkey. The mollusc shells (20-180 mg) were used for ${ }^{14} \mathrm{C}$ dating materials. The dates are expressed as uncalibrated.

\section{Optically Stimulated Luminescence (OSL) dating}

The quartz and feldspar minerals, which are the main constituents of sediments, are continually under the exposure of ionizing radiation. The absorbed dose by these crystals is the stored energy in the crystal structure of the mineral, and is a measure for the amount of ionizing radiation received by the mineral grain since its last exposure to daylight. An exposure to sunlight is needed to reset the luminescence signal in depositional environments. OSL provides an age estimation for the current sediment was exposed to sunlight which resets the luminescence signal (Huntley et al., 1985). In this study, optically stimulated luminescence (OSL) dating is applied to sediment samples to obtain depositional ages. In order to prevent OSL signal loss, the sample preparation method was carried out at the laboratory under red light. The sieved samples are first soaked in $1 \mathrm{~N}$ (normality) HCL to remove carbonate compositions. Secondly, $30 \% \quad \mathrm{H}_{2} \mathrm{O}_{2}$ solution is added to the sample in a beaker and mixed for $\sim 30$ minutes to extract the sample from organic compounds. The sample is sieved to obtain the $90-150 \mu \mathrm{m}$ grain size fractions. In the third step, $40 \% \mathrm{HF}$ solution is added to the sample in a beaker to remove the external alpha additive and dissolve the feldspar, and waited for 6080 minutes by mixing. Finally, 12N HCL solution is added and kept in this solution to remove possible remnant carbonate particles for $\sim 30$ minutes (Juyal et al., 2006; Bernt et al., 2018). Samples are washed three times with distilled water at the end of all acid washing processes. All minerals in the samples that are washed with distilled water consist of only quartz minerals. The etched quartz grains were dried at $50{ }^{\circ} \mathrm{C}$ in incubator, $25 \mathrm{mg}$ grains were scattered over a $8 \mathrm{~mm}$ diameter stainless steel disc with a silicon spray for OSL measurements Multi-grained aliquots are tested with the IRSL (infrared stimulated luminescence) signal to prevent feldspar contamination. In this study, any detectable IR signal was not observed. OSL measurements were carried out at $110^{\circ} \mathrm{C}$ trap combined with thermoluminescence trap and at $125^{\circ} \mathrm{C}$ to prevent retrapping (Murray and Wintle, 1998). CW-OSL (continuous wave optically stimulated luminescence) measurements were carried out with the Lexsyg Smart TL / OSL reader at the Luminescence Dating Laboratory, Physics Department, Çukurova University.

The following dating equation (Equation 1) was used to calculate the age with luminescence method (Huntley, 1985).

Age $=$ Equivalent Dose $(\mathrm{ED}) /$ Annual Dose $(\mathrm{AD})$ (Equation 1)

A single sample shows the change of OSL signal values obtained as a result of exposure to the artificial irradiation in the laboratory after the measurement of the natural OSL signal is given regarding the age of Equivalent Dose value 
with Regenerative Method (Aitken, 1998) (Fig. 2). In this study, each equivalent dose value was calculated by using the average of 3 aliquots. Besides, annual dose value was taken as $2.1 \mathrm{mGy} / \mathrm{a}$ considering the similar studies conducted in the region (Şahiner et al., 2013; Dogan et al., 2015).

\section{RESULTS}

\section{Lithology and Chronology}

The top two meters of drilling 10MB-201 consists of brownish-green and greenish-grey loose mud (Fig. 3a). The sediments of lower part consist of greenish stiff mud except for $81 \mathrm{~m}$ with $84.5 \%$ sand content. In drillings 10MB-203, 10MB-204 and 10MB-205, fine-coarse grained sands with shell and shell fragments interbedded with brownish green mud at the upper parts pass down to brownish green stiff muds. The lithology of drilling 10MB-206 is composed mainly of coarse-grained materials. Gravelly sand and shell fragments represent the interval between 40 - $55 \mathrm{~m}$ (Fig. 3b). The uppermost 10$15 \mathrm{~m}$ of drillings $10 \mathrm{MB}-207$ and 10MB-208 is composed predominantly of grey sand with shell fragments. The sand content sharply decrease at the lower parts of the drillings and are limited between $27.5 \%$ and $2.9 \%$. These levels are represented by brownish green muds.

10MB-205/10 m were analyzed with ${ }^{14} \mathrm{C}$ method in two different laboratories and the results yielded $49.0 \mathrm{ky}$ and $43.2 \mathrm{ky}$ of age (Table 2). According to the numerical age data results, the drilling sediments include the sedimentary records of MIS-5, MIS-3 and MIS-1.

\section{Benthic Foraminifera}

A total of 128 benthic foraminiferal species belonging to 75 genera were identified (Appendix 1, Figs. 4-9). The species richness was the highest in the samples from the Hersek Burnu drillings and ranged between 71 and 97 species/drilling. Dilovası drillings contain slightly fewer foraminifera compared with the Hersek Burnu drillings. Species of Bolivina, Elphidium, Bulimina and Ammonia are the dominant taxa in all analyzed samples.

In the Dilovas1 drillings, most of the levels are either barren of foraminifera (14 levels) or contain rare foraminifera (13 levels). The highest foraminiferal abundances (3328, 2900 and 1023 individuals/10 g dry sediment) are recorded at 10MB-205/1.5 m, 10MB-201/1 $\mathrm{m}$ and $81 \mathrm{~m}$, respectively (Table 3, Fig. 10a). 10MB201/81 $\mathrm{m}$ has low species richness (39 species). The microfaunistic assemblage is characterized by the abundance of Bulimina aculeata, Bolivina ordinaria, Aubignyna perlucida, Bulimina marginata, Bulimina elongata, Ammonia tepida and Nonionoides turgidus. Poor foraminiferal density (43 individuals/10 $\mathrm{g}$ dry sediment) and species richness (15 species) are observed at $74 \mathrm{~m}$. The assemblage is composed of species of the genera Haynesina, Ammonia, Elphidium and Cribroelphidium.
The uppermost $1 \mathrm{~m}$ has the highest species richness (79 species), and is represented mainly by Cassidulina carinata, Bolivina ordinaria, Discorbinella bertheloti, Bulimina aculeata, Neoconorbina terquemi, Cibicides sp., Gavelinopsis praegeri, Bolivina dilatata and Cibicidoides lobatulus, in order of abundances. Foraminifera are completely absent in drilling 10MB-203, except for few specimens at 95 and $100 \mathrm{~m}$. Foraminiferal fauna at the lower parts of 10MB-204 have sporadic occurrences with very low abundance, except for the bottom $69 \mathrm{~m}$, which contained Bolivina dilatata, $B$. spathulata and $B$. ordinaria. The uppermost $21.5 \mathrm{~m}$ are generally characterized by low foraminiferal density and species richness (maximum 220 individuals/10 g dry sediment and 28 species). The fauna includes Ammonia compacta, A. parkinsoniana, A. tepida, Ammonia spp., Asterigernata mamilla, Aubignyna perlucida, Bolivina. dilatata, $B$. ordinaria, B. spathulata, B. striatula, Bolivina spp., Bulimina. aculeata, B. elongata, Cassidulina carinata, Discorbinella bertheloti, Elphidium macellum, E. pulvereum, Elphidium spp. and Haynesina depressula. Both foraminiferal density (9-113 individuals/10 g dry sediment) and species richness (8-31 species) are low between $18-10 \mathrm{~m}$ of 10MB-205. The main components of the assemblages are represented by Bo. dilatata, Bo. ordinaria, C. carinata, Elphidium spp., H. depressula, Bo. spathulata, Bo. striatula, Fursenkoina complanata, A. parkinsoniana and $P$. subgranosus. High species richness (64 species) is recorded at $1.5 \mathrm{~m}$ and As. mamilla, D. bertheloti, C. carinata, Bo. dilatata, N. terquemi and E. macellum display significant abundances.

Hersek Burnu drillings have a rich and diverse foraminiferal fauna (Table 4, Fig. 10b). Benthic foraminiferal assemblages consisting of Bo. dilatata, Bo. spathulata, C. carinata, Elphidium spp., H. depressula, $B$. aculeata, Bo. ordinaria, Au. perlucida and Ammonia spp. occur at lower most $63 \mathrm{~m}$ of 10MB-206, in order of abundances. Despite the lack of foraminifera at the upper 53 and $45 \mathrm{~m}$, the dominance of Elphidium and Ammonia genera together with subordinately number of B. aculeata, C. carinata, H. depressula, Bo. dilatata and As. mamilla is conspicuous between $41-25.5$ m. B. aculeata (21.2$47.8 \%)$ and Bo. ordinaria (6.0-35.4\%) together with subordinately number of Bo. dilatata, N. turgidus, Bo. spathulata, Au. perlucida and B. marginata are consistently present towards the top part of the drilling. Benthic foraminiferal assemblages display two significant peaks in 10MB-207. Au. perlucida, A. tepida, A. parkinsoniana, Ammonia spp., $H$. depressula, $P$. subgranosus and Elphidium spp. are dominant in the first increment at $31 \mathrm{~m}$, whereas second peak at $18 \mathrm{~m}$ is characterized by high abundances of $B o$. ordinaria, $B$. aculeata, A. tepida, N. turgidus and Bo. dilatata, reaching to $65 \%$ in Total Benthic Foraminifera (TBF). A distinct faunal change appears at the upper parts of the drilling with the domination of Ammonia, Elphidium, Rosalina and Neoconorbina genera. In 10MB-208, TBF and species 
Table 2 Radiocarbon (uncalibrated) and OSL ages of selected levels from the İzmit Gulf drillings

\begin{tabular}{|c|c|c|c|c|c|}
\hline Drilling & $\begin{array}{l}\text { Depth } \\
\text { (m) }\end{array}$ & Dated material & $\begin{array}{l}\text { Laboratory num- } \\
\text { ber }\end{array}$ & Method & Date \\
\hline 10MB-201 & 74 & Sediment & & OSL & $38170 \pm 3225$ \\
\hline 10MB-201 & 94 & Sediment & & OSL & $54361 \pm 4897$ \\
\hline 10MB-203 & 120 & Sediment & & OSL & $87820 \pm 7974$ \\
\hline 10MB-203 & 136 & Sediment & & OSL & $110500 \pm 16000$ \\
\hline 10MB-204 & 18 & Mollusc shell & Poz-95936 & C-14 & $>46000$ \\
\hline $10 \mathrm{MB}-205$ & 10 & Mollusc shell & Poz-95937 & C-14 & $49000 \pm 3000$ \\
\hline 10MB-205 & 10 & Mollusc shell & TÜBİTAK-378 & C-14 & $43191 \pm 396$ \\
\hline $10 \mathrm{MB}-205$ & 14 & Mollusc shell & Poz-95938 & C-14 & $>46000$ \\
\hline 10MB-206 & 8 & Sediment & & OSL & $6195 \pm 480$ \\
\hline 10MB-206 & 18 & Mollusc shell & Poz-95939 & C-14 & $8360 \pm 50$ \\
\hline 10MB-206 & 25.5 & Mollusc shell & Poz-95940 & C-14 & $46000 \pm 2000$ \\
\hline $10 \mathrm{MB}-206$ & 33 & Mollusc shell & TÜBİTAK-379 & C-14 & $48443 \pm 639$ \\
\hline 10MB-206 & 45 & Sediment & & OSL & $51504 \pm 3399$ \\
\hline 10MB-207 & 31 & Mollusc shell & Poz-95942 & C-14 & $9230 \pm 50$ \\
\hline 10MB-207 & 39 & Sediment & & OSL & $40000 \pm 1824$ \\
\hline 10MB-207 & 43 & Sediment & & OSL & $41700 \pm 3515$ \\
\hline 10MB-208 & 14 & Mollusc shell & TÜBİTAK-380 & C-14 & $6586 \pm 38$ \\
\hline
\end{tabular}

richness show an increasing trend from bottom to top. The high abundances of Au. perlucida (57.4\%), A. tepida (9.9\%) and Ammonia spp. (27.0\%) at the bottom $37.5 \mathrm{~m}$ accompanied by B. aculeata, B. elongata, N. turgidus, Bo. ordinaria and $H$. depressula towards the upper parts. $A$. compacta, A. parkinsoniana, A. tepida, Ammonia spp., $C$. advenum, $C r$. gerthi, Cribroelphidium poeyanum and Elphidium spp. are the main abundant species at the top 9 $\mathrm{m}$.

\section{Ostracods}

The ostracod assemblages (74 species belonging to 45 genera) were identified in the seven drillings samples from Dilovasi (10MB-201, 203, 204, 205) and Hersek Burnu (10MB-206, 207, 208).

Scanning electron microscopy images of selected ostracods species, Ponto-Caspian originated species (Figs. 11-13) and Mediterranean originated species (Figs. 14-17) were determined Ponto-Caspian ostracod species are belong to genera Bacunella, Amnicythere, Euxinocythere, Tyrrenocythere, Loxoconcha, Loxocaspia and Cytherissa (Table $5 \& 6$ ), and indicate low salinity (fresh and brackish waters) from littoral to marine environments. (e.g. Olteanu, 1978, 2003-2004; Opreanu, 2008; Boomer et al., 2010; Schornikov, 2011; Ivanova et al., 2015; Zenina et al., 2017; Williams et al., 2018; Javadova, 2019). The species of Acanthocythereis, Aurila, Bosquetina, Bythocythere, Callistocythere, Costa, Cytheridea, Hiltermannicythere, Neonesidea, Paracytheridea, Pseudocytherura, Pseudopsammocythere, Pterygocythereis, Semicytherura and Urocythereis genera
(Table $5 \& 6$ ) consist of the Mediterranean assemblage (e.g. Bonaduce et al., 1975; Breman, 1975; Yassini, 1979; Mostafawi and Matzke-Karasz, 2006; Joachim and Langer, 2008).

The units in the northern part (Dilovas1) of the studied area consist of more thicker and older than the southern parts (Hersek Burnu) according to fauna, numerical and lithological data. The ostracod assemblages of drilling 10MB-201 point out the Ponto-Caspian origin ostracods (e.g. Candona schweyeri, Trapezicandona sp., Amnicythere reticulata, Euxinocythere (Maetocythere) lopatici, Amnicythere quinquetuberculata, Euxinocythere bacuana, Euxinocythere relicta and Loxoconcha immodulata) at $108 \mathrm{~m}, 104 \mathrm{~m}, 74 \mathrm{~m}$ and $70 \mathrm{~m}$; mixed group (Ponto-Caspian and Mediterranean originated) at 94 $\mathrm{m}$ and $81 \mathrm{~m}$. Mediterranean origin ostracods (e.g. Acantocythereis hystrix, Bosquetina carinella, Bythocythere minima, Callistocythere intricatoides, Cytheridea acuminata, Paracytheridea parallia and Semicytherura inversa) at the uppermost $1 \mathrm{~m}$.

Ponto-Caspian fauna at $147 \mathrm{~m}, 143.5 \mathrm{~m}$ and $120 \mathrm{~m}$, mixed fauna at $140 \mathrm{~m}, 95 \mathrm{~m}$ and $16.5 \mathrm{~m}$, and Mediterranean originated fauna at $100 \mathrm{~m}$ were found in drilling 10MB203.

A thick sedimentary sequence containing Ponto-Caspian ostracods between $69 \mathrm{~m}$ and $5 \mathrm{~m}$ is observed in the drilling core 10MB-204, except for $13 \mathrm{~m}, 9.3 \mathrm{~m}$ and $2 \mathrm{~m}$ which have a mixed or Mediterranean origin fauna (Table 5).

In the drilling core 10MB-205, the fauna includes PontoCaspian ostracods between $30 \mathrm{~m}$ and $14 \mathrm{~m}$, and relatively abundant Ponto-Caspian species together with 


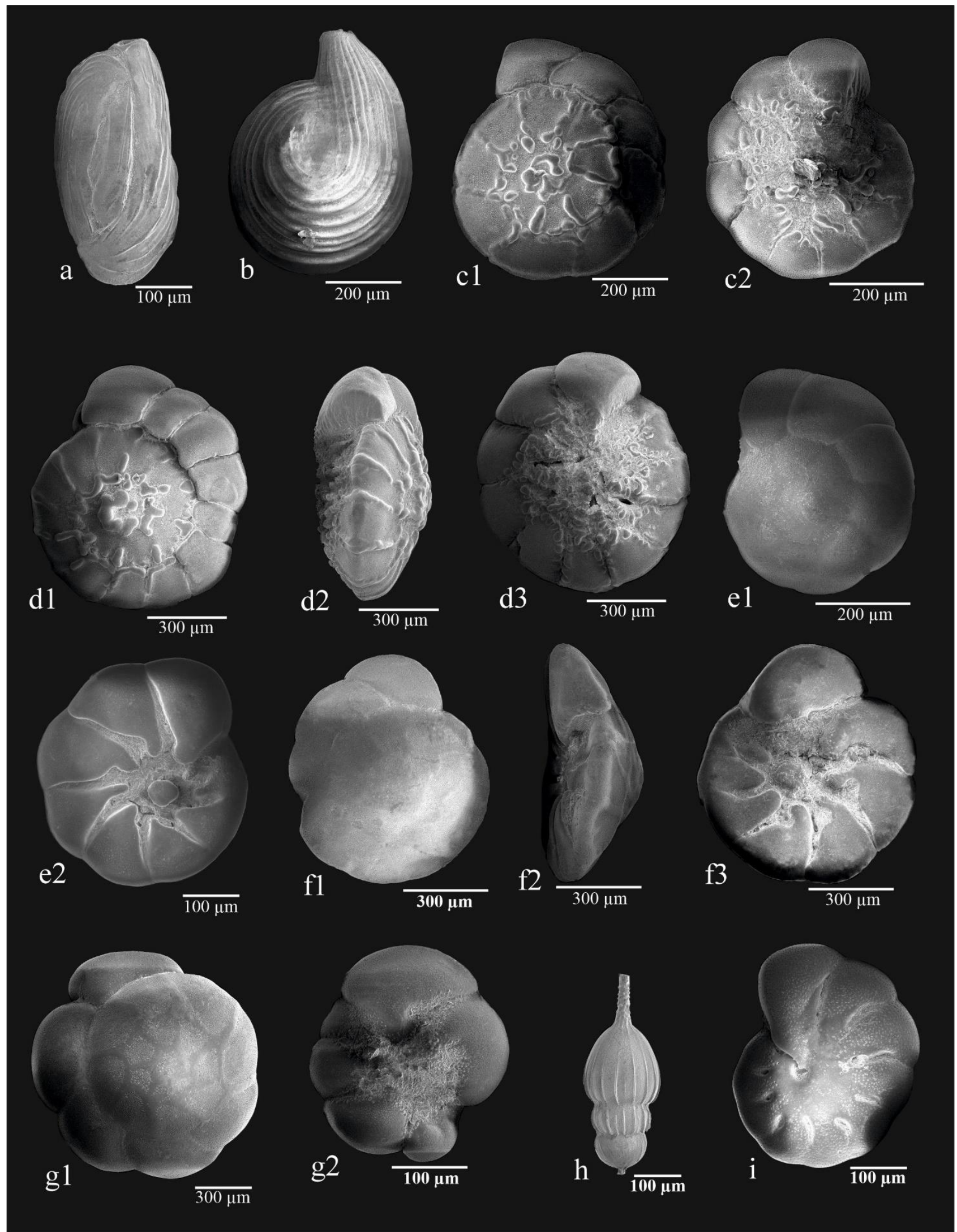

Fig. 4 Scanning electron micrographs of selected benthic foraminiferal species identified from the İzmit Gulf drilling cores. a. Adelosina carinatastriata, 208/5 m. b. Adelosina mediterranensis, 201/1 m. c. Ammonia compacta, 207/31 m: c1, spiral view; c2, umbilical view. d. Ammonia compacta, 208/1 m: d1, spiral view; d2, peripheral view; d3, umbilical view. e. Ammonia parkinsoniana, 206/37.5 m: e1, spiral view; e2, umbilical view. f. Ammonia parkinsoniana, 208/1 m: f1, spiral view; f2, peripheral view; f3, umbilical view. g. Ammonia tepida, 208/5 m: g1, spiral view; g2, umbilical view. h. Amphicoryna scalaris, 206/4.5 m. i. Astrononion stelligerum, 205/1.5 m. 


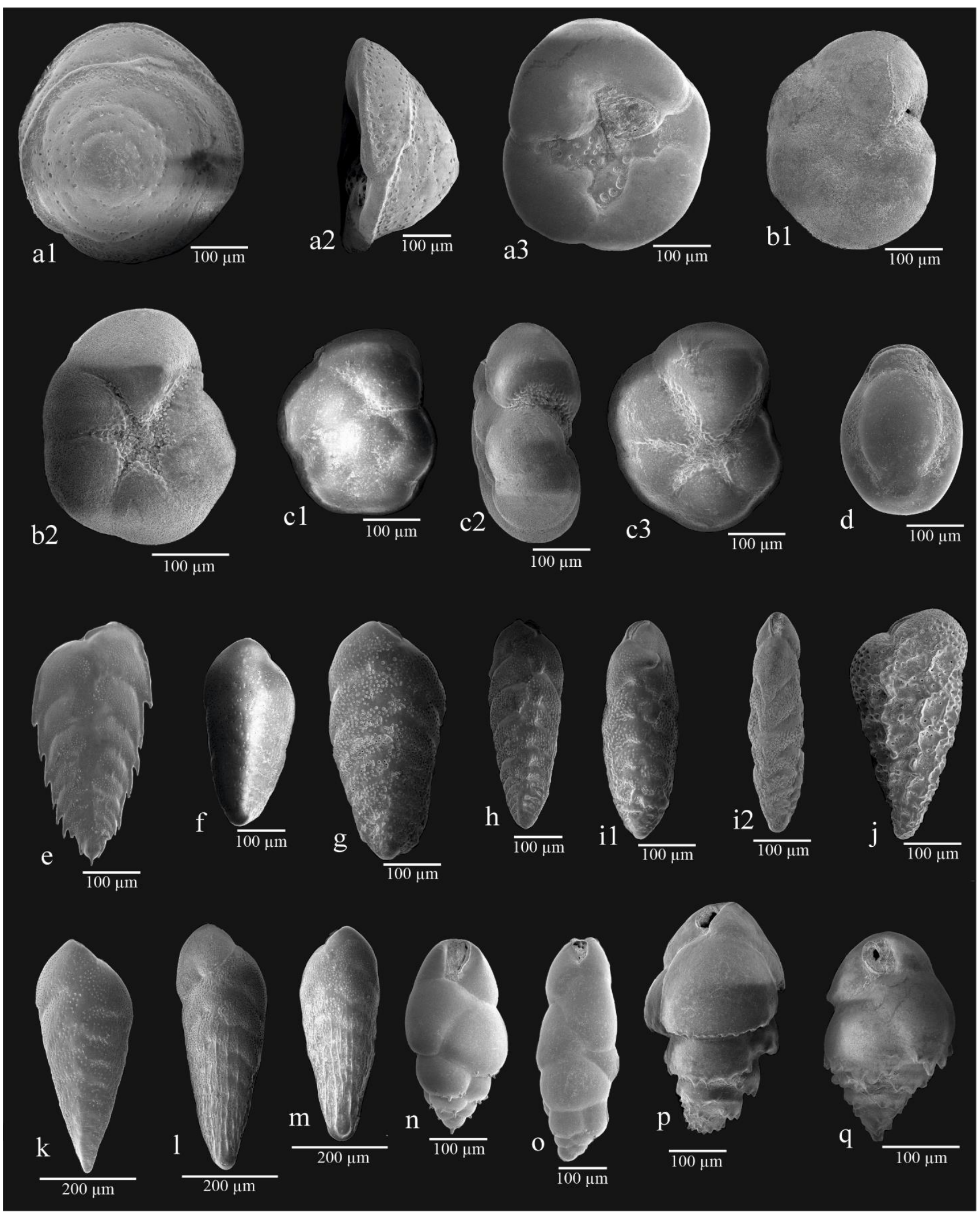

Fig. 5 Scanning electron micrographs of selected benthic foraminiferal species identified from the İzmit Gulf drilling cores. a. Asterigerinata mamilla, 206/37.5 m: a1, spiral view; a2, peripheral view; a3, umbilical view. b. Aubignyna perlucida, 208/37.5 m: b1, spiral view; b2, umbilical view. c. Aubignyna perlucida, 207/31 m: c1, spiral view; c2, peripheral view; c3, umbilical view. d. Biloculinella labiata, 204/13 m. e. Bolivina alata, 207/22 m. f. Bolivina dilatata, 206/37.5 m. g. Bolivina dilatata, 208/18 m. h. Bolivina ordinaria, 207/22.75 m. i. Bolivina ordinaria, 206/8 m: i1, side view; i2, apertural edge view. j. Bolivina pseudoplicata, 206/37.5 m. k. Bolivina spathulata, 206/37.5 m. I. Bolivina striatula, 206/14 m. m. Bolivina striatula, 208/25 m. n. Bulimina aculeata, 208/33 m. o. Bulimina elongata, 208/18 m. p. Bulimina marginata, 207/18 m. q. Bulimina marginata, 207/22.75 m. 


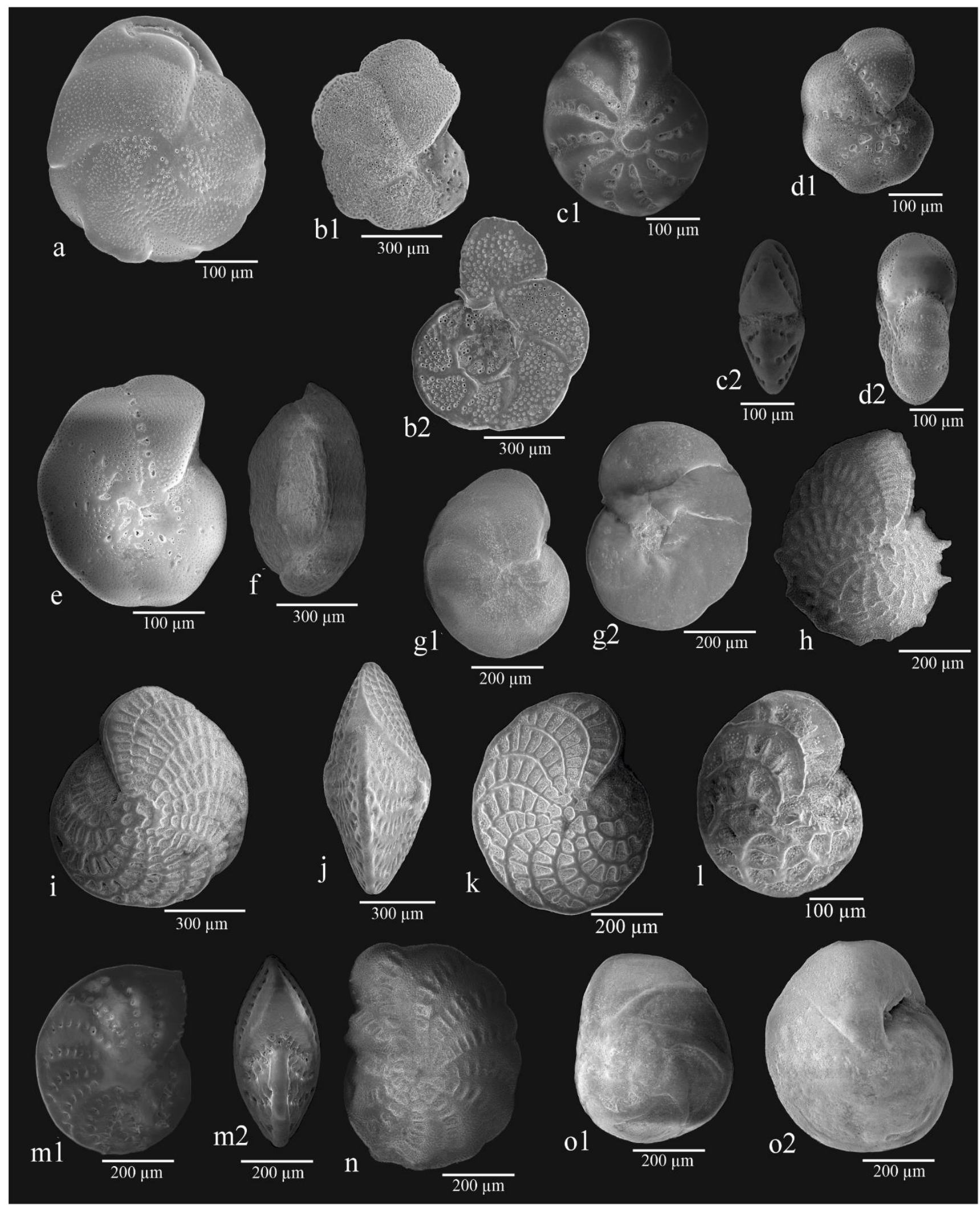

Fig. 6 Scanning electron micrographs of selected benthic foraminiferal species identified from the İzmit Gulf drilling cores. a. Cassidulina carinata, 206/33 m. b. Cibicidoides lobatulus, 206/37.5 m: b1, spiral view; b2, umbilical view. c. Cribroelphidium gerthi, 208/1 m: c1, side view; c2, apertural edge view. d. Cribroelphidium poeyanum, 207/31 m: d1, side view; d2, apertural edge view. e. Cribroelphidium poeyanum, 208/9 m. f. Cycloforina villafranca, 208/1 m. g. Discorbinella bertheloti, 205/1.5 m: g1, spiral view; g2, umbilical view. h. Elphidium aculeatum, 208/18 m. i. Elphidium crispum, 208/1 m. j. Elphidium crispum, 206/41 m. k. Elphidium macellum, 207/22.75 m. l. Elphidium macellum, 206/41 m. m. Elphidium punctatum, 208/1 m: m1, side view; m2, apertural edge view. n. Elphidium sp. 208/1 m. o. Eponides concameratus, 206/41 m: o1, spiral view; o2, umbilical view. 
a

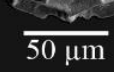

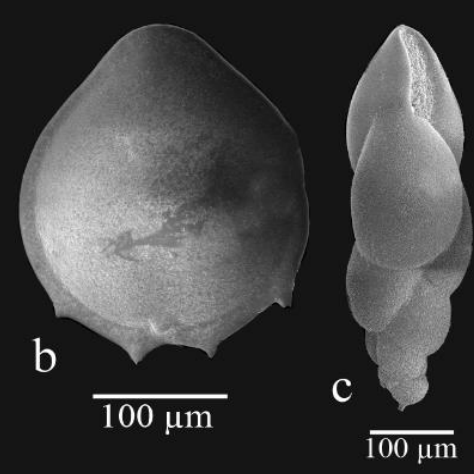
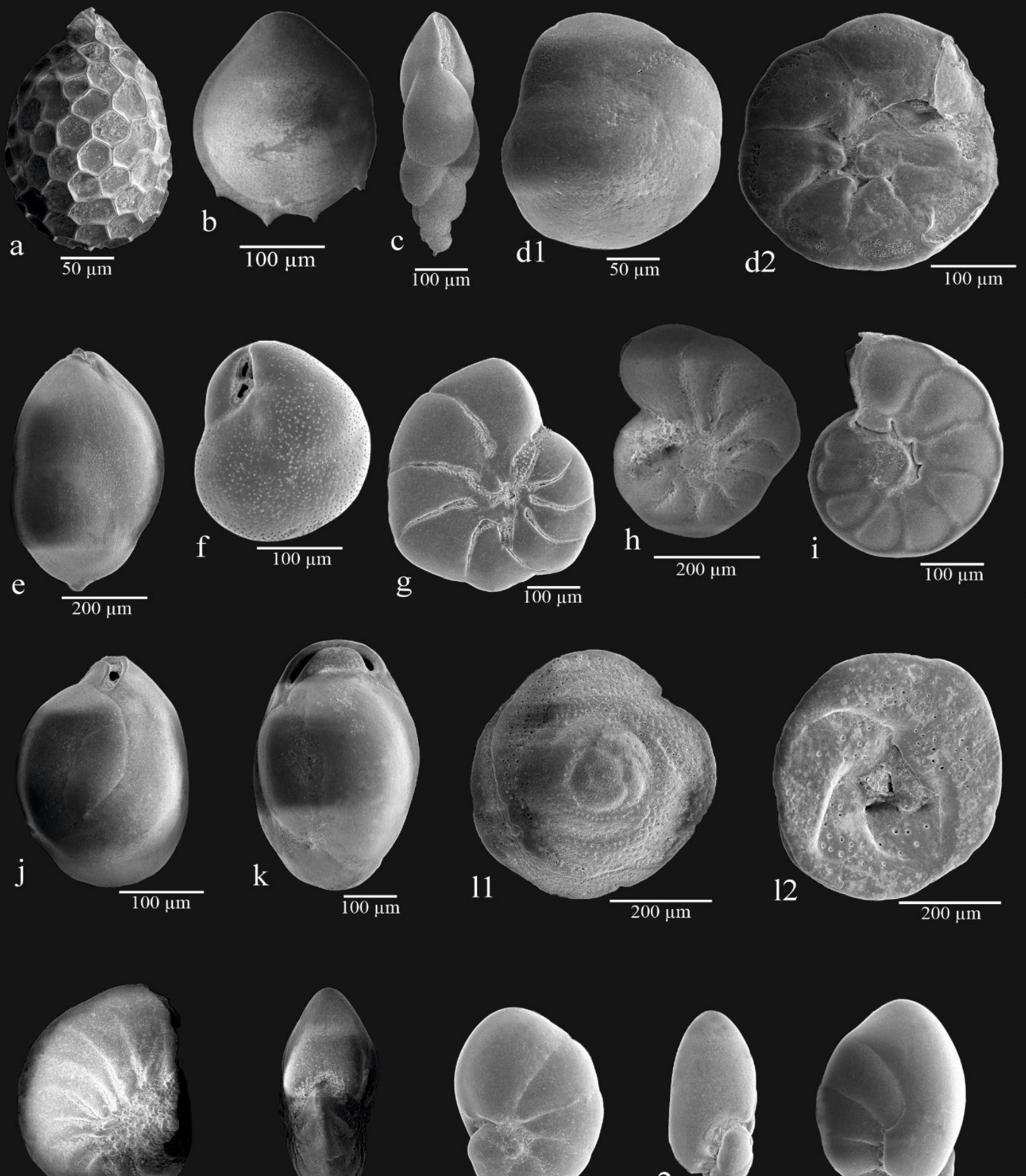

$\mathrm{m} 1$
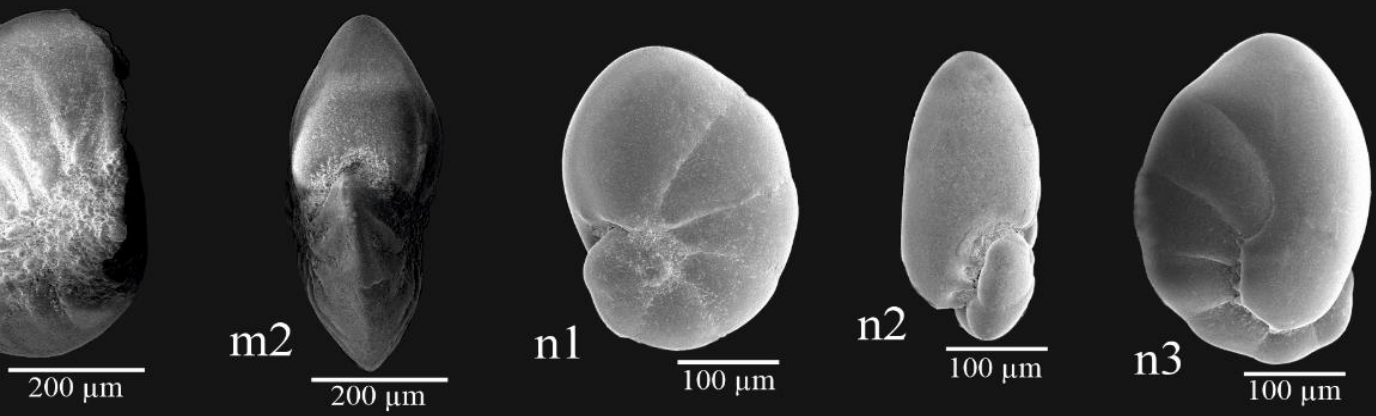

Fig. 7 Scanning electron micrographs of selected benthic foraminiferal species identified from the İzmit Gulf drilling cores. a. Favulina hexagona, 206/37.5 m. b. Fissurina staphyllearia, 206/37.5 m. c. Fursenkoina complanata, 206/14 m. d. Gavelinopsis praegeri, 206/37.5 m: d1, spiral view; d2, umbilical view. e. Globobulimina affinis, 201/1 m. f. Globocassidulina subglobosa, 201/1 m. g. Haynesina depressula, 206/33 m. h. Haynesina sp., 208/1 m. i. Hyalinea balthica, 206/33 m. j. Miliolinella subrotunda, 208/5 m. k. Miliolinella subrotunda, 208/9 m. l. Neoconorbina terquemi, 208/5 m: 11, spiral view; 12, umbilical view. m. Nonion subturgidum, 206/41 m: m1, side view; m2, apertural edge view. n. Nonionoides turgidus, 208/33 m: n1, spiral view; n2, peripheral view; n3, umbilical view. 


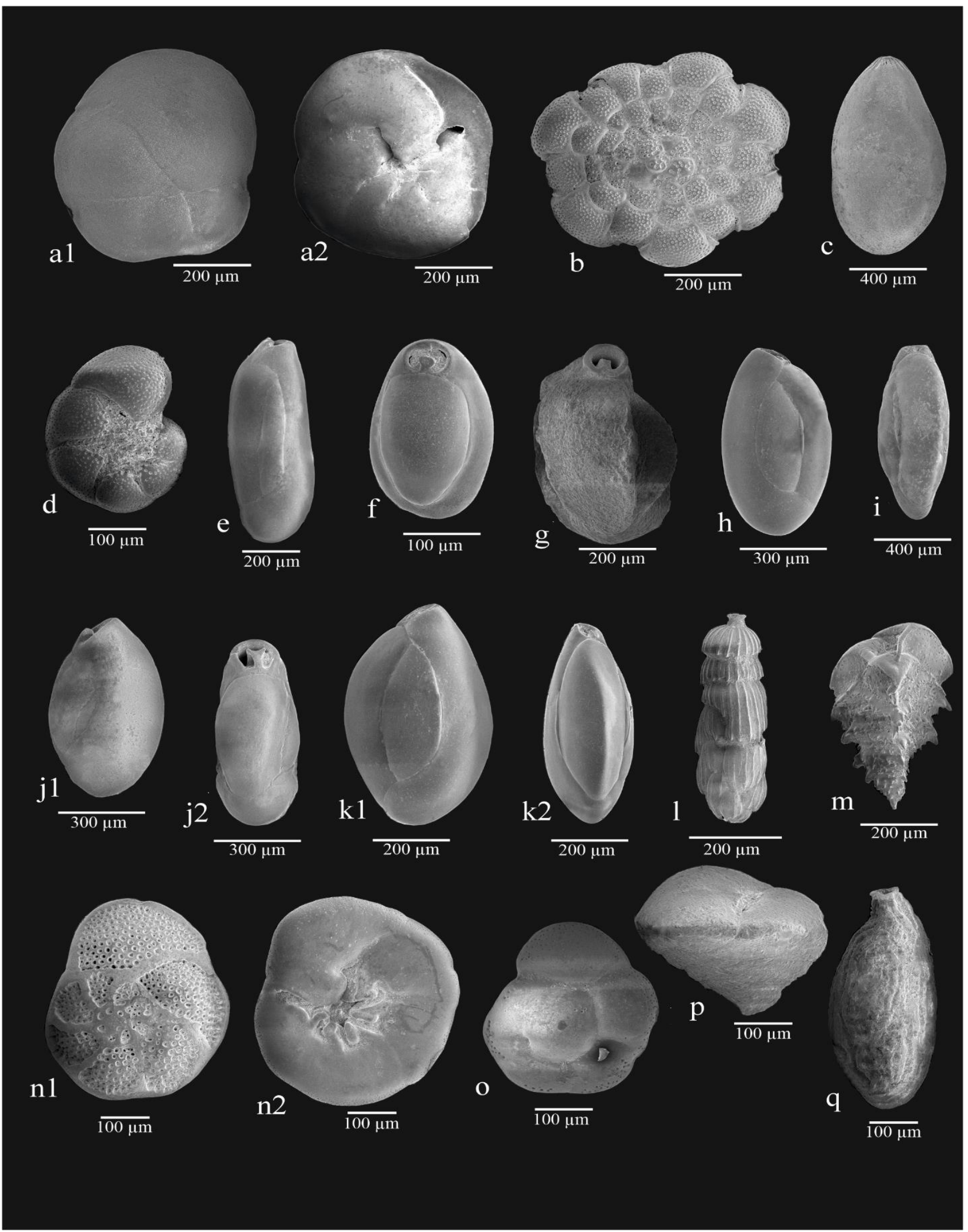

Fig. 8 Scanning electron micrographs of selected benthic foraminiferal species identified from the İzmit Gulf drilling cores. a. Planodiscorbis sp., 205/1.5 m: a1, spiral view; a2, umbilical view. b. Planorbulina mediterranensis, 201/1 m. c. Polymorphina sp., 206/41 m. d. Porosononion subgranosus, 207/31 m. e. Pseudotriloculina lecalvezae, 207/1 m. f. Pyrgo elongata, 201/1 m. g. Quinqueloculina berthelotiana, 208/1 m. k. Quinqueloculina laevigata, 208/9 m. i. Quinqueloculina laevigata, 208/2 m. j. Quinqueloculina parvula, 208/5 m: j1, side view; j2, apertural edge view. k. Quinqueloculina seminula, 201/1 m: k1, side view; k2, apertural edge view. I. Rectuvigerina phlegeri, 205/1.5 m. m. Reusella spinulosa, 201/1 m. n. Rosalina bradyi, 208/5 m: n1, spiral view; n2, umbilical view. o. Rosalina globularis, 208/1 m. p. Sahulia conica, 201/1 m. q. Sigmoilina costata, 208/5 m. 


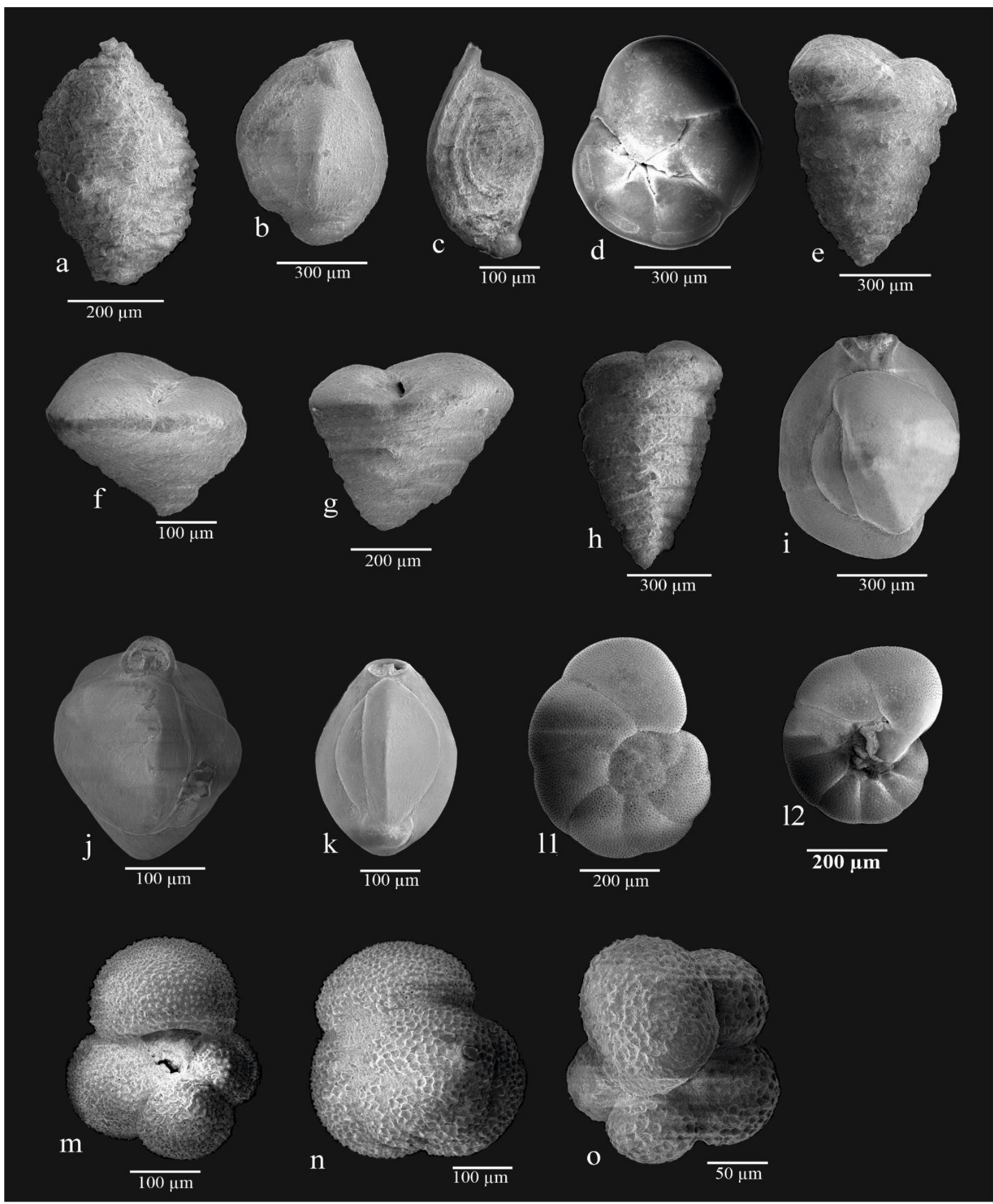

Fig. 9 Scanning electron micrographs of selected benthic foraminiferal species identified from the İzmit Gulf drilling cores. Three planktic species rarely observed in the drillings are illustrated in $\mathbf{m}, \mathbf{n}$ and $\mathbf{o}$. a. Sigmoilopsis schlumbergeri, 201/1 m. b. Siphonaperta sp., 208/5. c. Spirophthalmidium tenuiseptatum, 201/1 m. d. Stomatorbina concentrica, 207/5 m. e. Textularia aglutinans, 208/9 m. f. Textularia calva, 201/1 m. g. Textularia pala, 205/1.5 m. h. Textularia sagittula, 201/1 m. i. Triloculina marioni, 207/1 m. j. Triloculina plicata, 208/1 m. k. Triloculina tricarinata, 205/1.5 m. l. Valvulineria bradyana, 206/37.5 m: 11, spiral view; 12, umbilical view. m. Globigerina bulloides, 207/22 m. n. Globigerinoides ruber, 201/1 m. o. Turborotalita quinqueloba, 201/1 m. 
Table 3 Percentage composition of representative species in the Dilovasi drillings. Species having $\geq 3 \%$ abundance were accepted as environmentally representative species and were shaded in gray color on the table. Number of specimens are presented as numbers per $10 \mathrm{~g}$ dry sediment. Drilling 10MB-203 is not shown due to absence of a representative foraminiferal fauna.

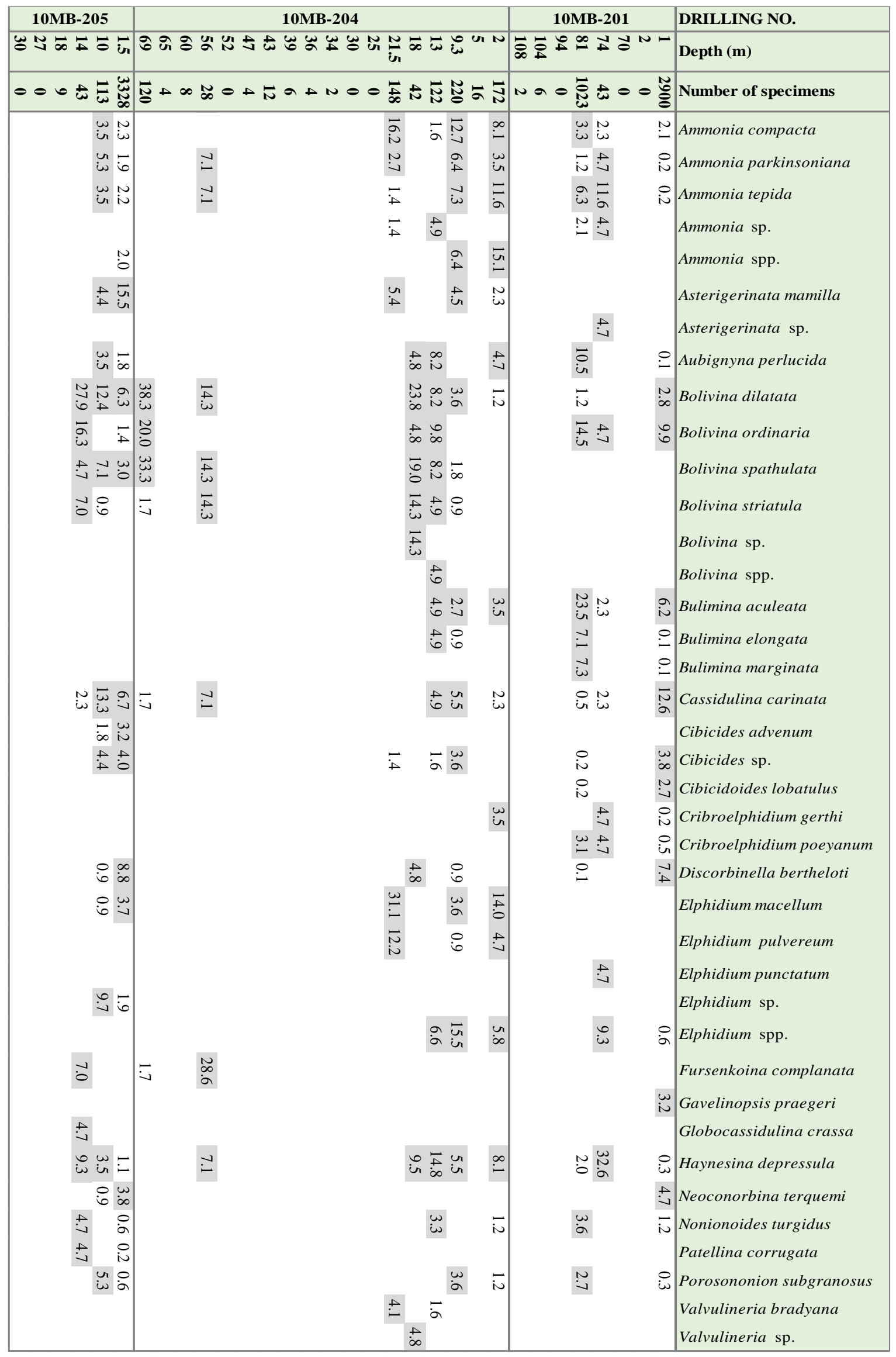


Table 4 Percentage composition of species in the Hersek Burnu drillings, showing relative abundances $\geq 3 \%$. Species having $\geq 3 \%$ abundance were accepted as environmentally representative species and were shaded in gray color on the table. Number of specimens are presented as numbers per $10 \mathrm{~g}$ dry sediment.

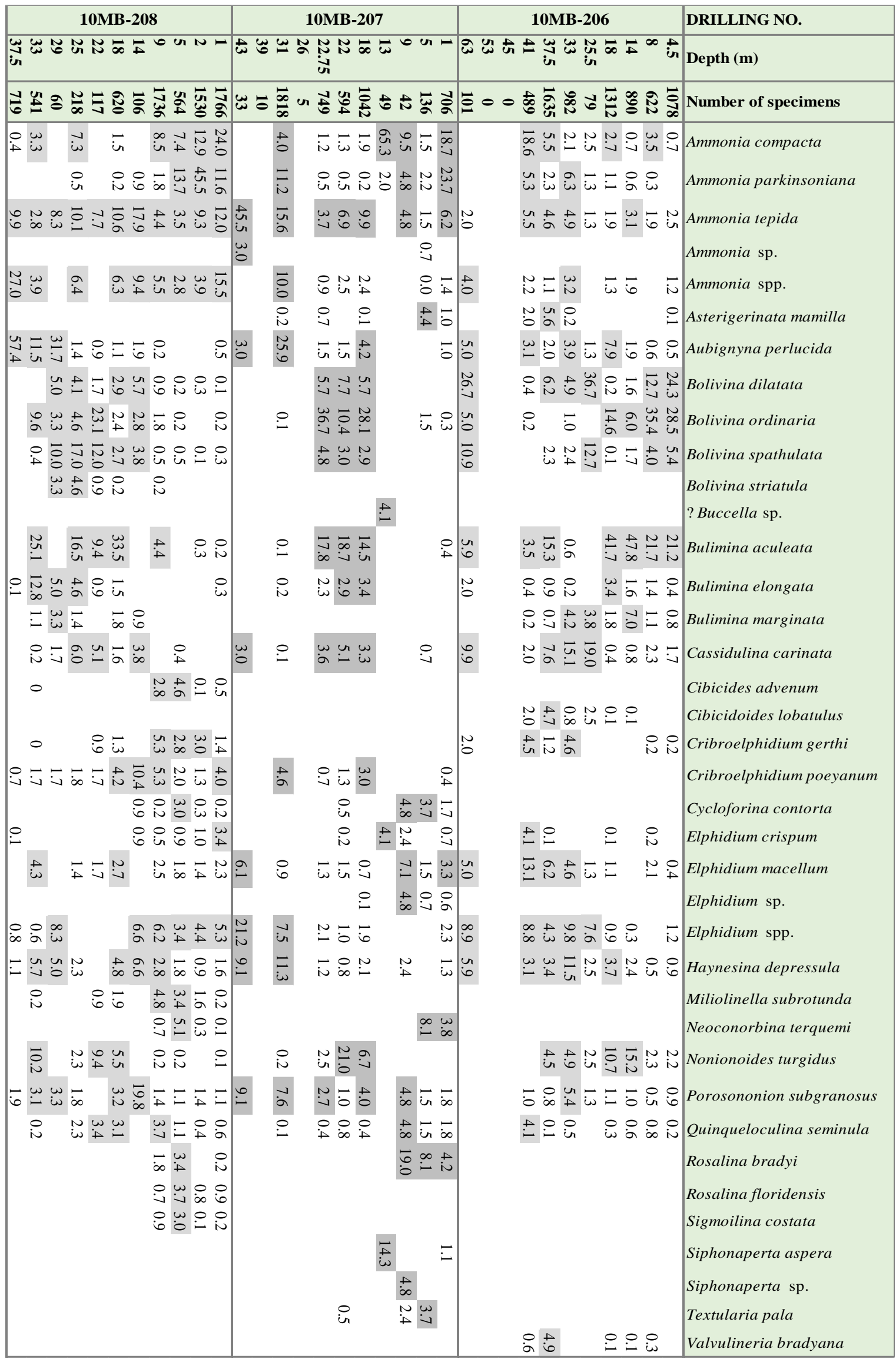


Mediterranean species at $10 \mathrm{~m}$ (Table 5). Mediterranean origin ostracod species were found at the uppermost $1.5 \mathrm{~m}$. After the reconnection of Mediterranean and The Marmara Sea via the Strait of Dardanelles during the early Holocene (Aksu et al., 1999), the ostracods of the southern drillings (Hersek Burnu, Table 6) is mainly represented by the Mediterranean origin species and a few relict PontoCaspian fauna. The ostracod fauna of Ponto-Caspian origin are represented by a few species at different levels of 10MB-206, 10MB-207 and 10MB-208 drillings while the highest species diversity of them is recorded at $63 \mathrm{~m}$ (Table 6).

\section{Molluscs}

In this study, 21 genera and 21 species belonging to the Gastropoda class, 12 genera and 14 species belonging to the Bivalvia class of the Mollusca were identified (Table 7 and Figs. 18-20). A large part of the identified gastropod and bivalv samples were probably broken up during drilling while coring, and were not well preserved. They are also smaller than they should be and are in juvenile forms. The identification was made by considering the observable features as much as possible. Black Sea origin species such as Pirenella conica, Bythinella pannonica (Meriç et al., 2005) and Mediterranean origin species such as Lucinella divaricata, Parvicardium exigium, Spisula subtruncata (Kerey et al., 2004) were detected together at $1 \mathrm{~m}$ and $81 \mathrm{~m}$ of the 10MB-201 drilling. Black Sea origin species such as Dreissena rostriformis distincta, Dreissena rostriformis tschuadae (Neveskaja, 1963) were identified between 16.5 - 95 m of 10MB-203 borehole and 13 -69 m between 10MB-204 borehole. The fauna of Mediterranean and Black Sea origin was observed together between $2-9.5 \mathrm{~m}$ in the 10MB-204 borehole and at $1.5-14 \mathrm{~m}$ in the 10MB-205 borehole. Bivalvia at 18 - 30 meters of the 10MB-205 borehole are of Black Sea origin. In the 10MB-206 drill, a single Black Sea origin genus at $25.5 \mathrm{~m}$, Black Sea and Mediterranean species together at $41 \mathrm{~m}$ and Black Sea origin Dreissena sp. was found at $63 \mathrm{~m}$. Both Mediterranean and Black Sea origin gastropods and bivalvs were found together between 1 - $26 \mathrm{~m}$ of 10MB-207 borehole and 1-22 m of 10MB-208 borehole; Mediterranean species were relatively dominant.

\section{Diatoms}

The diatom flora consist in 15 species assigned to 10 genera in the three samples of drilling 10MB-203 (143.5 $\mathrm{m}, 140 \mathrm{~m}$ and $95 \mathrm{~m}$, Table 8, Fig. 21). All of the taxa were recorded in low densities. Sample from $143.5 \mathrm{~m}$ has four pennate diatom form (Amphora libyca, Diploneis parma, Epithemia turgida var. westermannii and Fragilaria lancettula and two centric forms (Cyclotella comensis and Stephanodiscus lucens). Only one pennate diatom (Amphipleura pellucida) was identified in $95 \mathrm{~m}$. Relatively high species richness is observed at 95 $\mathrm{m}$, consisting of six pennate diatom forms (Amphipleura pellucida, Cocconeis disculus, Diploneis elliptica, Diploneis parma, Fragilaria sp., Stenopterobia sigmatella) and six centric diatom forms (Actinocyclus normanii, Stephanodiscus aegyptiacus, S. alpinus, S. lucens, S. medius and S. niagarae).

\section{DISCUSSION AND CONCLUSIONS}

Global climatic changes in the form of glacial and interglacial cycles occur during the Quaternary (Lowe and Walker, 1984). Remarkable expansion and contraction of glacial masses were recorded in the Northern Hemisphere during glacial and interglacial periods. Depending on these events, the hydrodynamic regimes of water systems (rivers, lakes, seas etc.) have changed due to the vertical oscillations resulted from the rises or drops in the water levels.

The fluctuating sea level caused connections or disconnections between basins and hence the formation of different environmental settings. One of the most important area, the Marmara Sea, which provides the only connection of Ponto-Caspic basins (Black Sea, Azov Sea and Caspian Sea) with the open sea (Mediterranean) (Stanley and Blanpeid, 1980).

According to the age data of this research, the sediments are Late Pleistocene-Holocene aged and correspond to the marine isotope stage MIS-5, MIS-3 and MIS-1 (Fig. 22). The unconformity between MIS-3 and MIS-1 is clearly observed based on the numerical age data. The lack of records for MIS- 4 and MIS- 2 can be explained by the fact that this region was affected by the North Anatolian Fault, because it may be exposed to subaerial erosion in lowwater levels during the glacial period or the sampling frequency was inadequate. It is also important to keep in mind that the sediment gaps from the drillings have restricted a high-resolution sampling.

\section{Pleistocene / MIS-5 Interval}

The thickest sequence from drilling 10MB-203, recovered from $-40 \mathrm{~m}$ in Northern Dilovas1, and had the oldest sedimentary records extending back to MIS-5 (Fig. 22). MIS-5 stage is characterized by the Ponto-Caspian ostracod fauna such as Camptocypria acronasuta, Bacunella dorsoarcuta, Candona parallela pannonica, Amnicythere olivia, Amnicythere. reticulata, Loxocaspia lepida, Xestoleberis chanakovi, Candona schweyeri, Amnicythere pediformis, A. postbissinuata, Euxinocythere (Maetocythere) lopatici, Euxinocythere bacuana, Tyrrenocythere amnicola donetziensis and Loxoconcha immodulata, except for $140 \mathrm{~m}$ which had a mixed ostracod fauna originated from the Ponto-Caspian and Mediterranean. The diatom flora includes some fresh water and cosmopolitan species consisting of Amphora libyca, Cyclotella comensis, Epithemia turgida var. westermannii, Fragilaria lancettula and Amphipleura pellucida. Foraminifera are completely absent in the sediments deposited during MIS-5. 
Table 5 Distribution of Ponto-Caspian and Mediterranean origin and cosmopolitan ostracods in Dilovasi drillings.

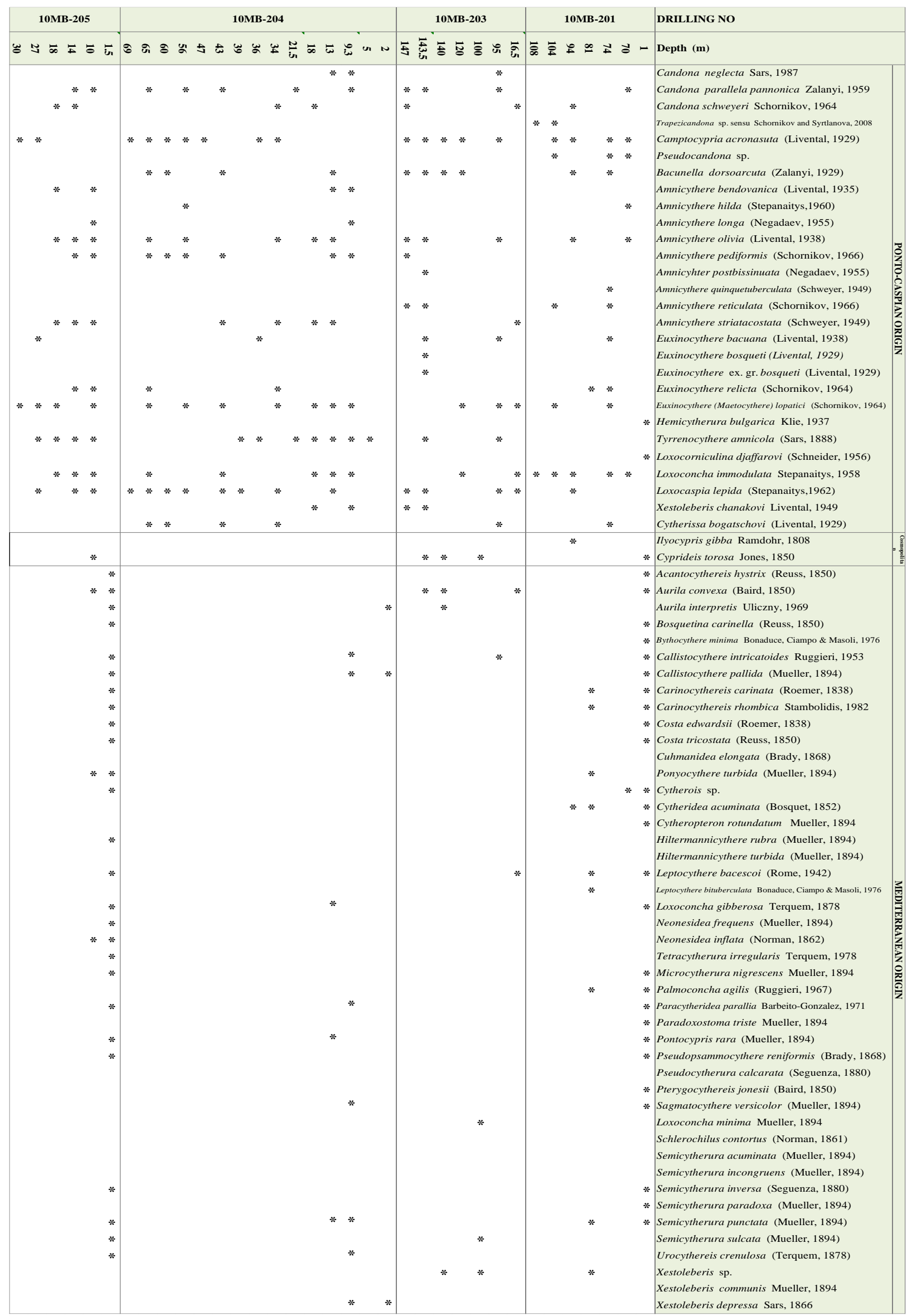


Table 6 Distribution of Ponto-Caspian and Mediterranean origin and cosmopolitan ostracods in Hersek Burnu drillings.

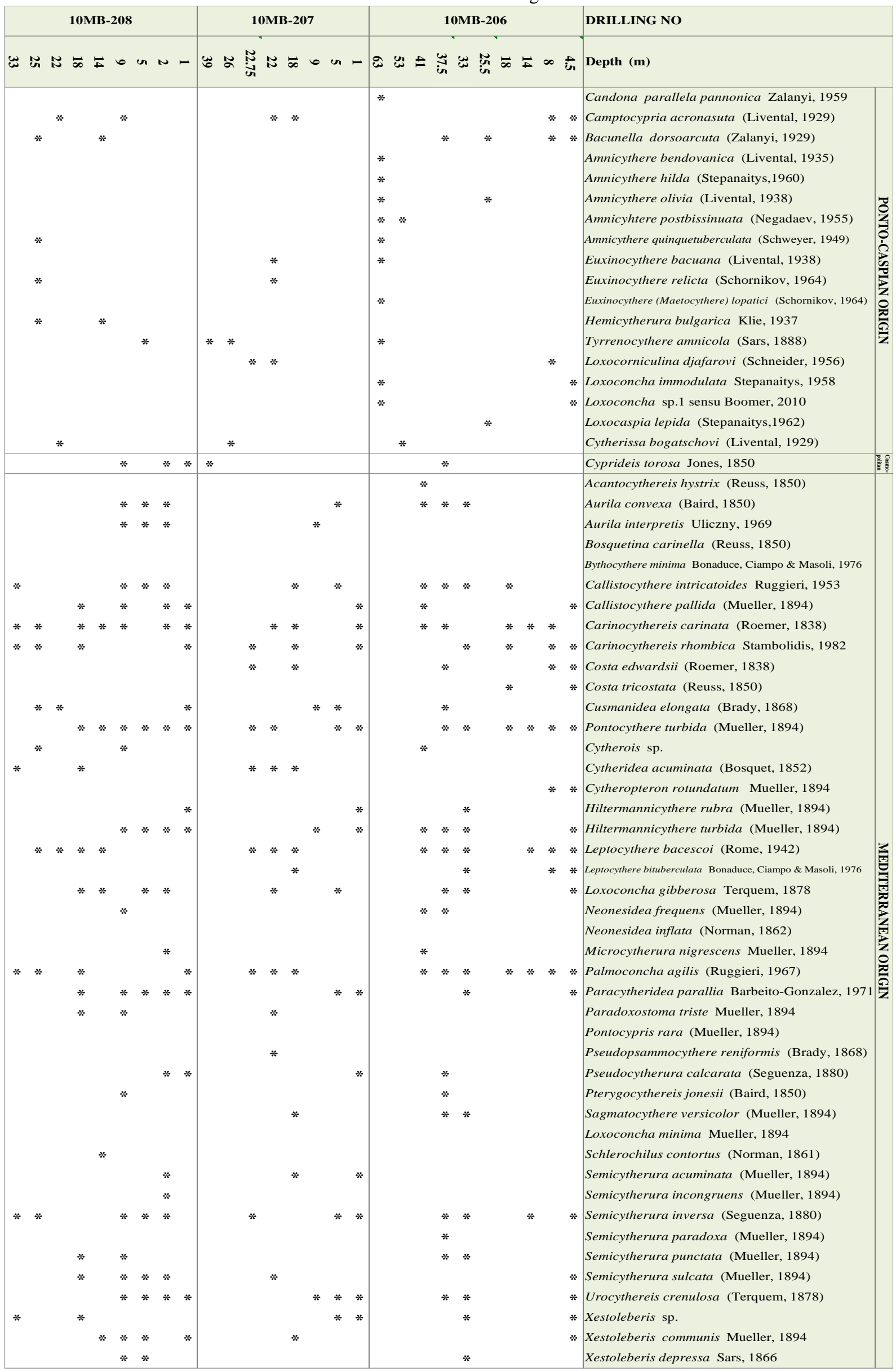


Elmas Kırcı -Elmas, Atike Nazik, Sevinç Kapan, Engin Meriç, Emine Şeker Zor, Beste Kalkan, Tamer Doğan \& Ayşegül Güney

Table 7 Distribution of molluscs in all drillings.

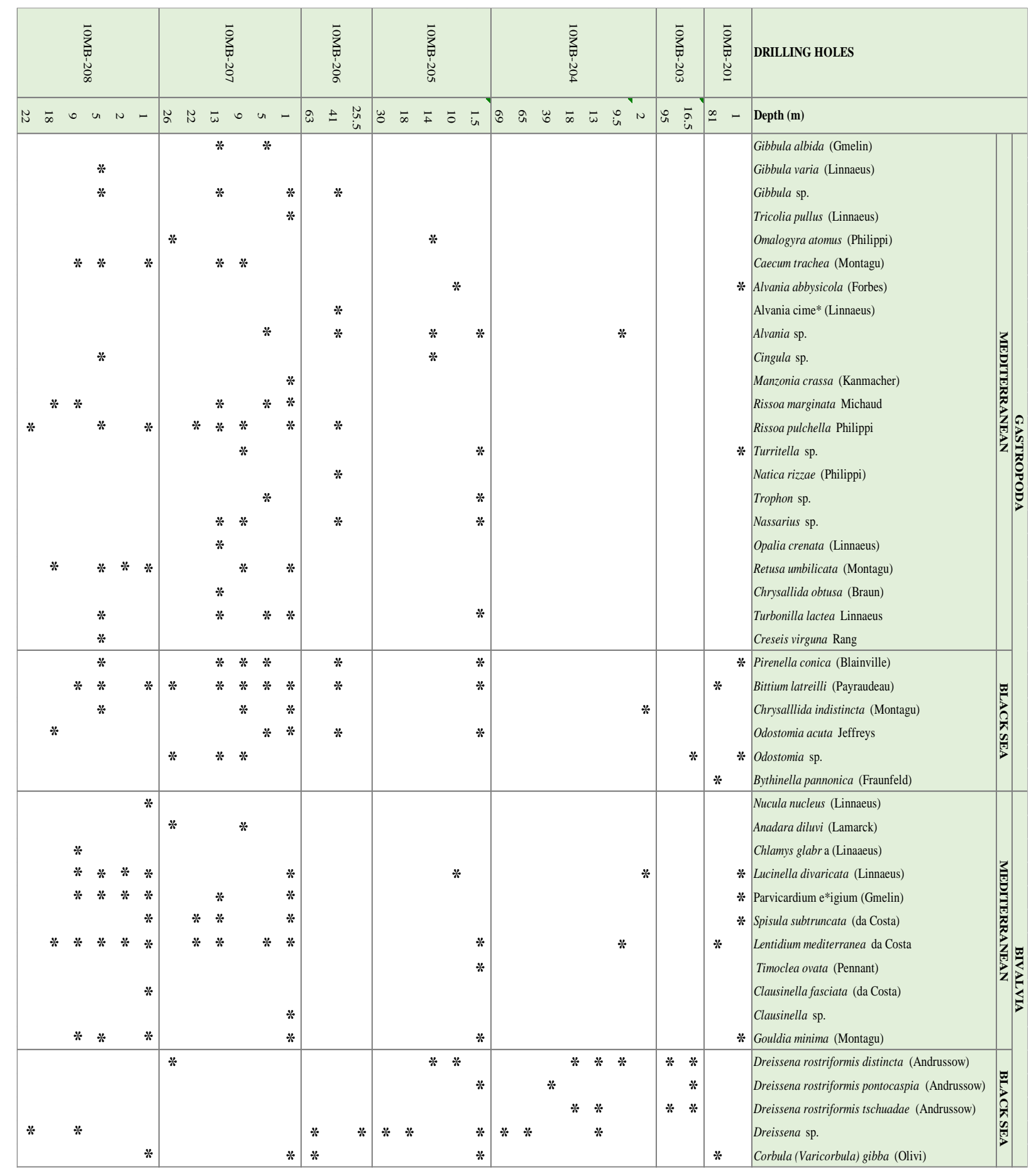


Table 8 Distribution of diatoms in drilling 10MB-203 (ecological characteristics of the identified taxa from studies of Wetzel (1983), Round (1956, 1984), Krammer and Lange-Bertalot (1986a, 1986b, 1988, 1991), Van Dam et al. (1994), Trojanowski et al. (2001), Pala (Toprak) and Çağlar (2006), Round et al. (2007), Taş and Gönülol (2007), Zaim (2007), Sivaci et al. (2007, 2008, 2013), Kistenich et al. (2014), Varol and Şen (2014), URL-1 - 11).

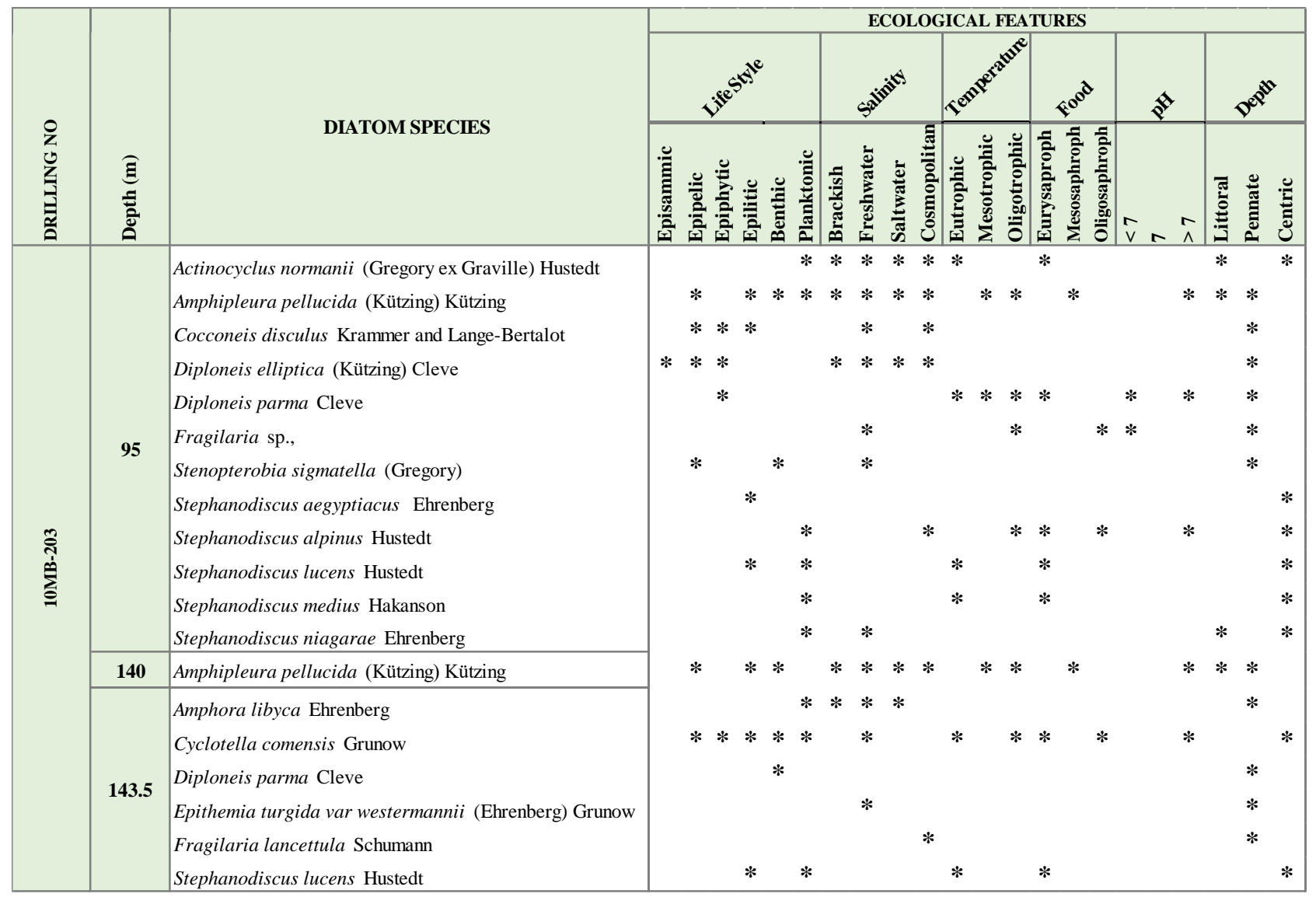

According to the global sea level curve (Chappell and Shackleton, 1986) and the data from the Ponto-Caspian basins (e.g., Sorokin, 2011; Yanina, 2014), there was a Mediterranean inflow into the Black Sea during MIS-5. The Çanakkale Strait was subaerially exposed at the peak of glacial oxygen isotopic stage 6 (Pleistocene), causing the Marmara Sea to become a lake. Even the low presence of marine elements and abundance of Ponto-Caspian ostracods together with fresh water and cosmopolitan diatom flora in our samples that the shallow water areas were still invaded by brackish waters.

\section{Pleistocene / MIS-3 Interval}

The sediments deposited during MIS-3 were observed in both northern and southern drillings (10MB-201, 203, 204, 205, 206 and 207; Fig. 22). The ostracods have three main assemblages consisting of Ponto-Caspian ostracods, Mediterranean ostracods and Ponto-Caspian and Mediterranean mixed fauna. The OSL numerical ages were obtained as $54.4 \mathrm{ky}$ at $94 \mathrm{~m}$ of 10MB-201 and 38.2 $\mathrm{ky}$ at $74 \mathrm{~m}$. In this age range, faunal groups (foraminifera, ostracod and mollusc) reflecting the Mediterranean influence was found. The older sediments at $108 \mathrm{~m}$ and $104 \mathrm{~m}$ and younger sediments at $70 \mathrm{~m}$ are barren of foraminifera and totally dominated by Ponto-Caspian ostracods, such as Candona parallela pannonica, Trapezicandona sp. sensu Schornikov et Syrtlanova, 2008, Camptocypria acronasuta, Pseudocandona sp., Amnicythere hilda, A. olivia, A. reticulata, Euxinocythere (Maetocythere) lopatici and Loxoconcha immodulata. Mediterranean influence is most noticeable at $81 \mathrm{~m}$, where a rich and diverse foraminiferal fauna, mixed ostracods dominated by Mediterranean originated species (e.g., Carinocythereis carinata, Carinocythereis rhombica, Pontocythere turbida, Cytheridea acuminata, Leptocythere bacescoi, L. bituberculata, Palmoconcha agilis, Semicytherura punctata and Xestoleberis sp.) and Mediterranean originated bivalvia (Lentidium mediterranea) were recorded. Foraminifera fauna is represented by high numbers of $B$. aculeata, Bo. ordinaria, Au. perlucida, B. marginata, B. elongata, A. tepida and $N$. turgidus, reflecting marine influence. Ostracod fauna at 74 $\mathrm{m}$ consists entirely of Ponto Caspian species (Caspiolla acronasuta, Pseudocandona sp., Bacunella dorsoarcuta, Amnicythere quinquetuberculata, A. reticulata, Euxinocythere relicta, Euxinocythere (Maetocythere) lopatici, Loxoconcha immodulata and Cytherissa bogatschovi). The foraminiferal fauna its low density and species richness is mainly represented by Haynesina, 


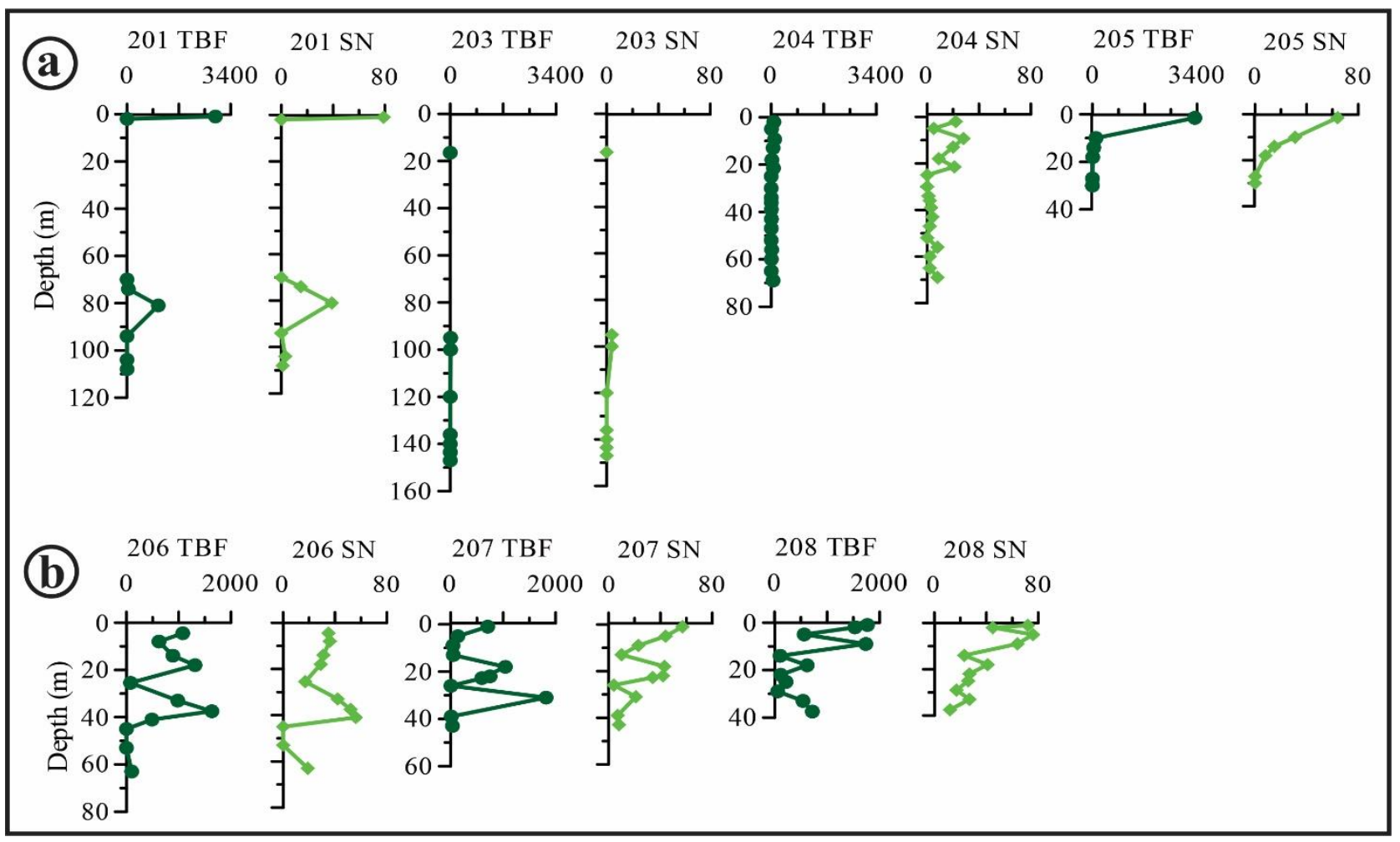

Fig. 10 Total Benthic Foraminifera (TBF) and Species Number (SN) in drillings a. Dilovas1 and b. Hersek Burnu. TBF indicates numbers of specimens per $10 \mathrm{~g}$ dry sediment. The lower intervals of drillings 10MB-204 (120-80 m), 10MB-205 (117.2-40 m), 10MB$206(122-80 \mathrm{~m}), 10 \mathrm{MB}-207(120.9-50 \mathrm{~m})$ and 10MB-208 (200-40 m) are not shown due to absence of sample.

Elphidium and Ammonia which tolerates a wide range of euryhaline conditions (Murray, 1973 1991; Hayward et al., 1999). These findings are comparable with the faunal characteristics at $100 \mathrm{~m}$ and $95 \mathrm{~m}$ of 10MB-203. In addition, fresh water and cosmopolitan diatom flora (Actinocyclus normanii, Amphipleura pellucida, Cocconeis disculus, Diploneis elliptica, Fragilaria sp., Stenopterobia sigmatella, Stephanodiscus alpinus, and $S$. niagarae) occur at $95 \mathrm{~m}$ of $10 \mathrm{MB}-203$.

Radiocarbon ages yielded $>46.0 \mathrm{ky}$ at both 18 th $\mathrm{m}$ of drilling 10MB-204 and 14th m of 10MB-205 and at two different ages as 49.0 and $43.2 \mathrm{ky}$ at 10th $\mathrm{m}$ of 10MB-205. In adition to the radiocarbon ages, OSL age is $28.5 \mathrm{ky}$ at 56th $\mathrm{m}$ of 10MB-204. This age difference may be due to the transitions and transportations between clastic sedimentary layers, as well as the fact that the quartz samples used in all OSL measurements are based on the assumption that the fading (when exposed to light) properties are the same. Domination of Ponto-Caspian ostracods (Candona parallela pannonica, C. schweyeri, Caspiolla acronasuta, Bacunella dorsoarcuta, Amnicythere bendovanica, A. hilda, A. olivia, A. pediformis, A. striatacostata, Euxinocythere (Maetocythere) lopatici, Euxinocythere bacuana, E. relicta, Tyrrenocythere amnicola donetziensis, Loxoconcha immodulata, Loxocaspia lepida, Xestoleberis chanakovi and Cytherissa bogatschovi) and bivalvia (Dreissena rostriformis distincta, D. rostriformis pontocaspia, D. rostriformis tschuadae and Dreissena sp.) at lower parts of the both the drillings are related to the 42 presence of Black Sea water body in the area. The occurrences of some normal marine and euryhaline benthic foraminiferal species at $69 \mathrm{~m}$ and $56 \mathrm{~m}$ of $10 \mathrm{MB}-$ 204 and $14 \mathrm{~m}$ of 10MB-205 (e.g., Bo. dilatata, Bo. ordinaria, Bo. spathulata, Bo. striatula, Bolivina sp., $C$. carinata, F. complanata, $H$. depressula, E. macellum, E. pulvereum, A. compacta, A. parkinsoniana, A. tepida, As. mamilla, Au. perlucida, D. bertheloti, and Valvulineria sp.) may be associated with the fluctuations of water salinity resulted from the Mediterranean inflows. PontoCaspian and Mediterranean originated mixed ostracods together with foraminifera at $13 \mathrm{~m}$ and $9.3 \mathrm{~m}$ of $10 \mathrm{MB}-204$ and $10 \mathrm{~m}$ of $10 \mathrm{MB}-205$ indicate the increasing Mediterranean inflows.

When considering the radiocarbon and OSL dates from the southern drillings, it is noteworthy that the ages are clearly concentrated in the time interval between $40.0-52.0 \mathrm{ky}$ BP. In this time interval, Ponto-Caspian ostracods and bivalves are represented by Candona parallela pannonica, Amnicythere hilda, A. olivia, A. postbissinuata, A. quinquetuberculata, Euxinocythere (Maetocythere) lopatici, E. bacuana, T.e amnicola donetziensis, L. immodulata, Loxoconcha sp 1 sensu Boomer, 2010, Cytherissa bogatschovi, Bacuniella dorsoarcuta, Loxocaspia lepida and Dreissena sp., Corbula (Varicorbula) gibba, respectively. Aditionally, low numbers and and poorly diverse foraminifera (e.g., Bo. dilatata, Bo. spathulata, C. carinata, H. depressula, B. aculeata, Bo. ordinaria, Au. perlucida, Ammonia spp. and Elphidium spp.) occur at some levels. At the interval 


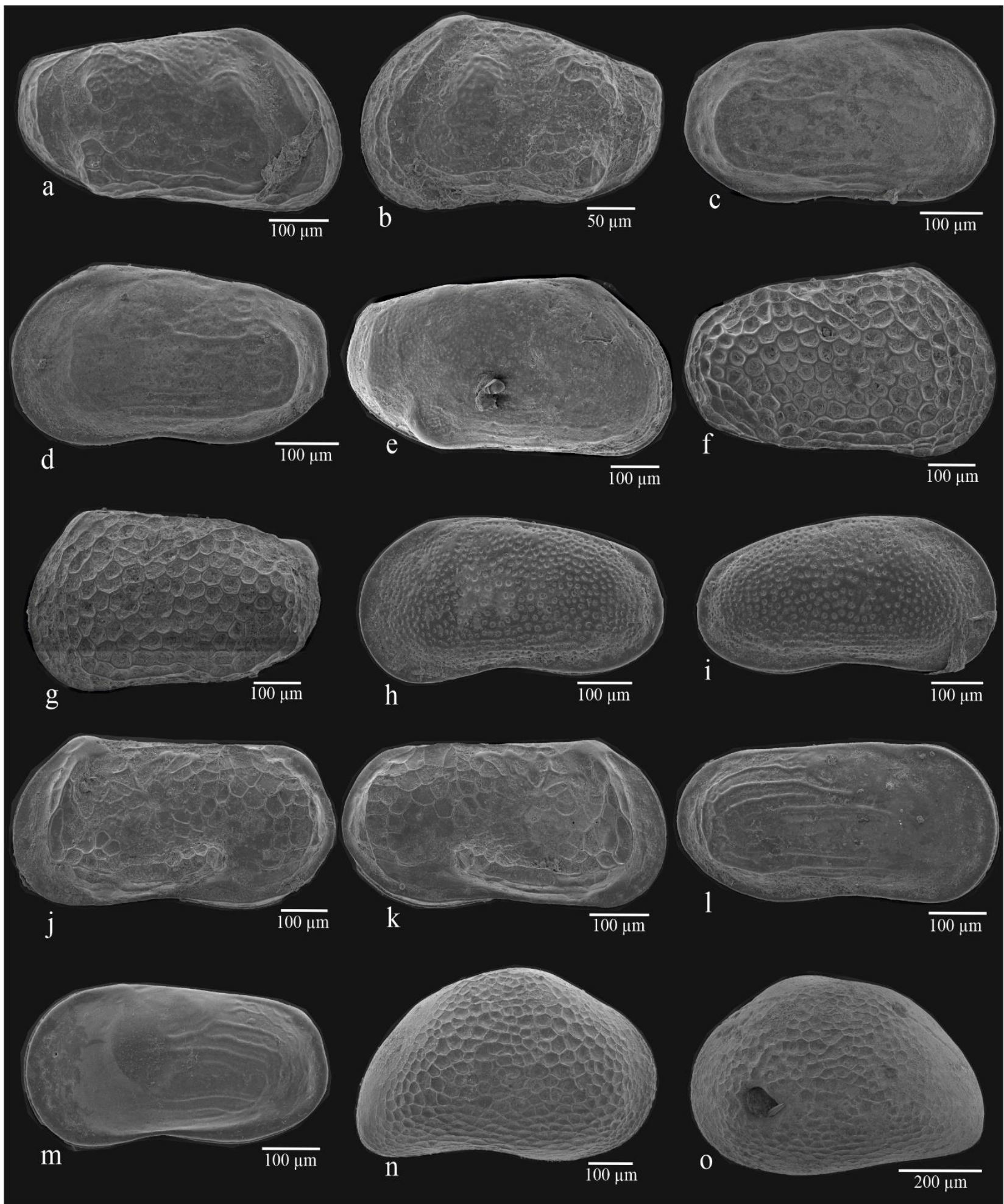

Fig. 11 Scanning electron micrographs of selected Ponto-Caspian origin ostracod species identified from the İzmit Gulf drilling cores. a-b. Amnicythere bendovanica; a right valve, 204/9.3 m, b left valve, 204/13 m; c-d. Amnicythere hilda; c right valve, d left valve, 204/56 m; e. Amnicythere longa; right valve, 204/9.3 m; f-g. Amnicythere olivia; f right valve, g left valve, 204/34 m; h-i. Amnicythere pediformis; $\mathbf{h}$ left valve, i right valve, 204/13 m; j-k. Amnicythere quinquetuberculata; $\mathbf{j}$ left valve, $\mathbf{k}$ right valve, 206/63 m; l-m. Amnicythere striatacostata; $\mathbf{l}$ right valve, 204/34 m; m left valve, 204/18 m; n-o. Bacunella dorsoarcuata; $\mathbf{n}$ right valve, o left valve 204/43 m. 


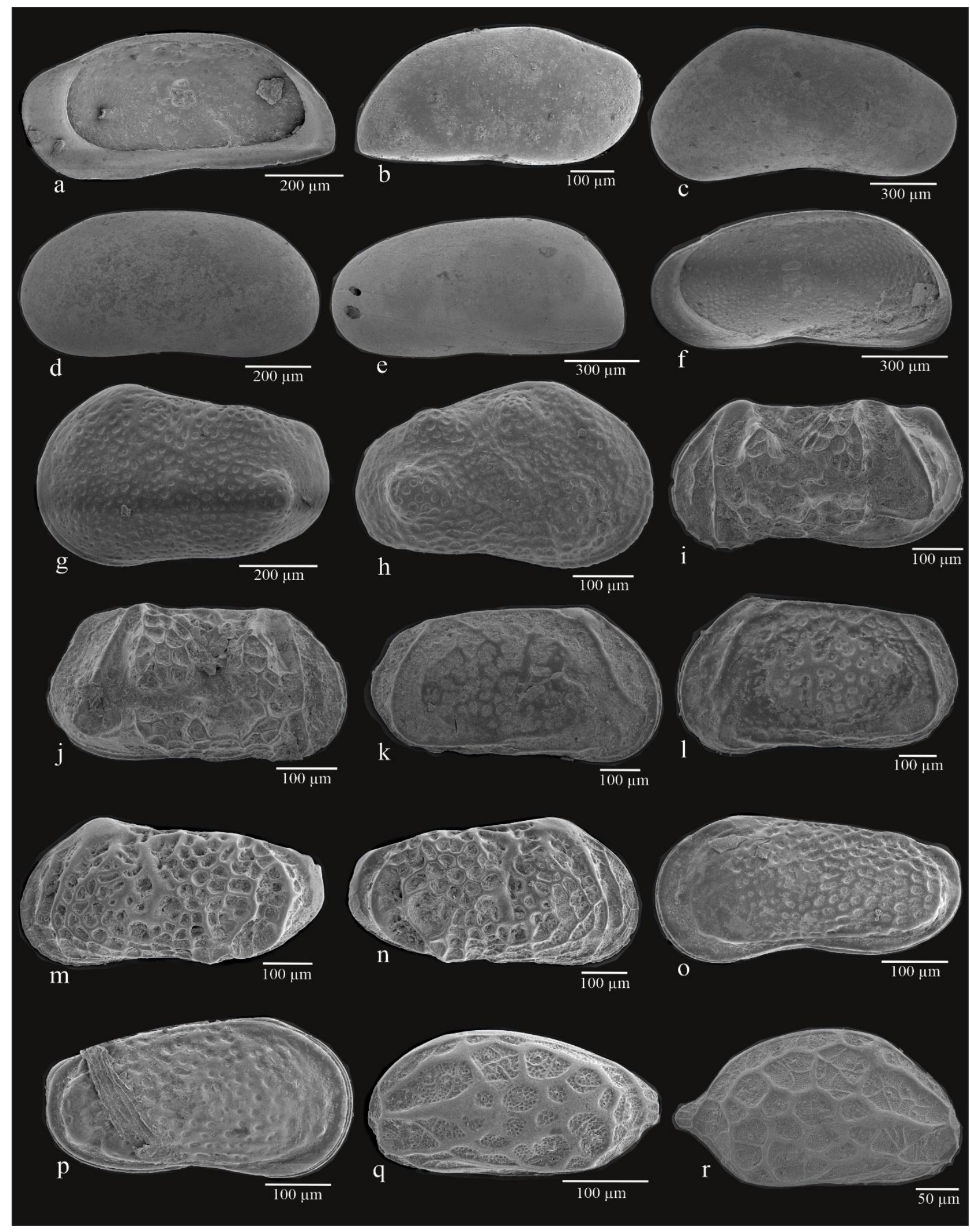

Fig. 12 Scanning electron micrographs of selected Ponto-Caspian origin ostracod species identified from the İzmit Gulf drilling cores. a-b. Camptocypria acronasuta; a right valve, internal view, b right valve, 201/104 m; c. Candona neglecta; right valve, 204/9.3 m; d. Candona parallela pannonica; left valve, 204/9.3 m; e-f. Candona schweyeri; e left valve, 204/34 m, f right valve, internal view, 204/18 m; g-h. Cryptocyprideis bogatschovi; g left valve, h right valve, 204/43 m; i-j. Euxinocythere bacuana; i left valve, 203/95 m, j right valve, 206/63 m; k-l. Euxinocythere bosqueti; k right valve, 204/36 m, l right valve, 203/143.5 m; m-n. Euxinocythere ex gr. bosqueti; m left valve, 203/143.5 m; n left valve; o-p. Euxinocythere relicta; o left valve, p right valve, 201/74 m, 10 m; q-r. Hemicytherura bulgarica; q left valve, male 208/14 m, r right valve, female, 201/1 m. 


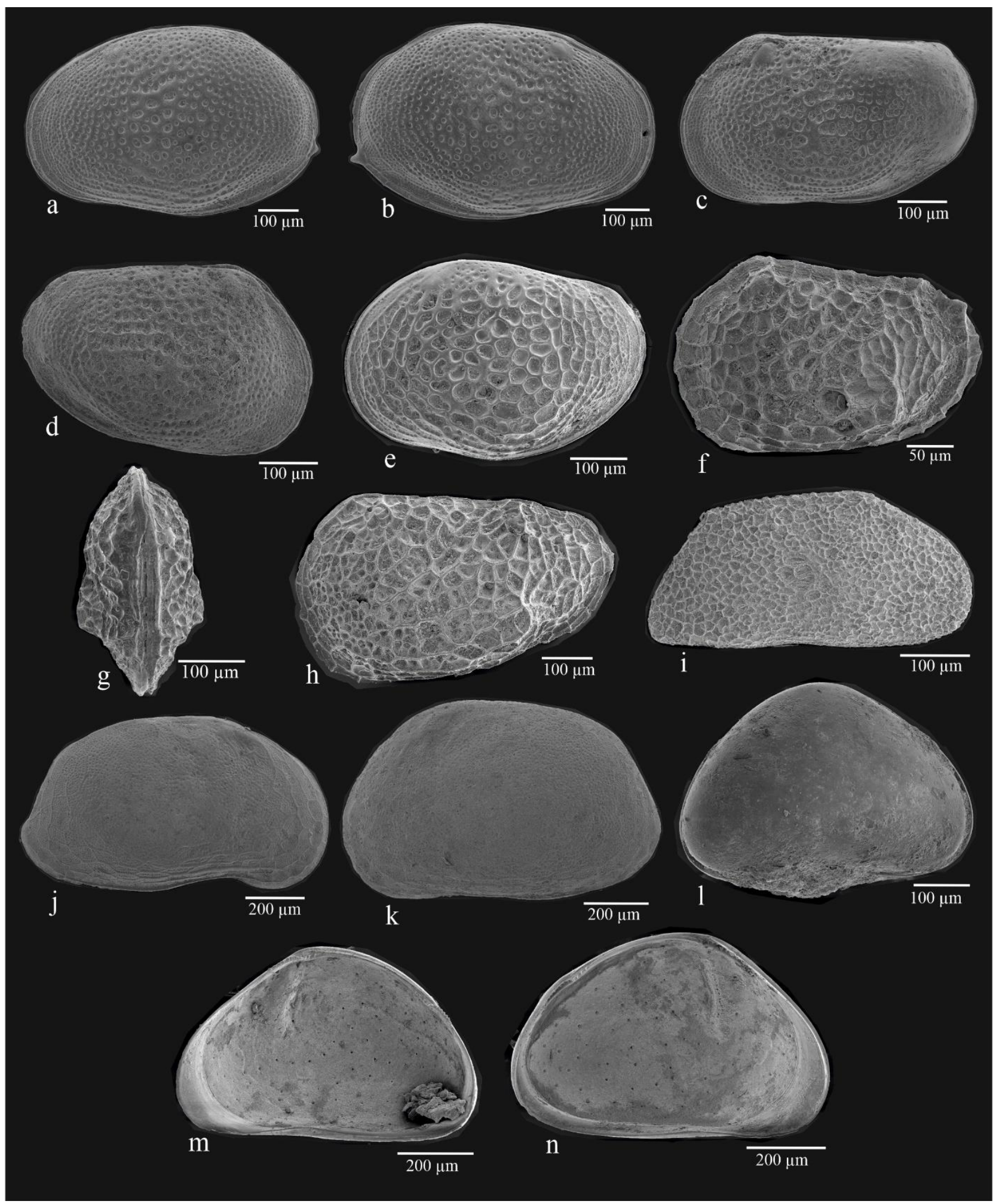

Fig. 13 Scanning electron micrographs of selected Ponto-Caspian origin ostracod species identified from the İzmit Gulf drilling cores. a-b. Loxocaspia lepida; a left valve, b right valve, 204/9.3 m; c-d. Loxoconcha immodulata; c left valve, male, d left valve, female, 204/9.3 m; e. Loxoconcha sp.; left valve, 206/63 m; f-h. Loxocorniculina djaffarovi; f left valve, 207/22.75 m, g dorsal view, 207/22.75 m, h left valve, 206/8 m; i. Trapezicandona sp.; right valve, 201/108 m; j-k. Tyrrhenoythere amnicola donetziensis; $\mathbf{j}$ right valve, $\mathbf{k}$ left valve, 204/9.3 m; l-n. Xestoleberis chanakovi; l right valve, 203/143.5 m; m right valve, internal view, 203/147 m; $\mathbf{n}$ left valve, internal view, 203/147 m. 


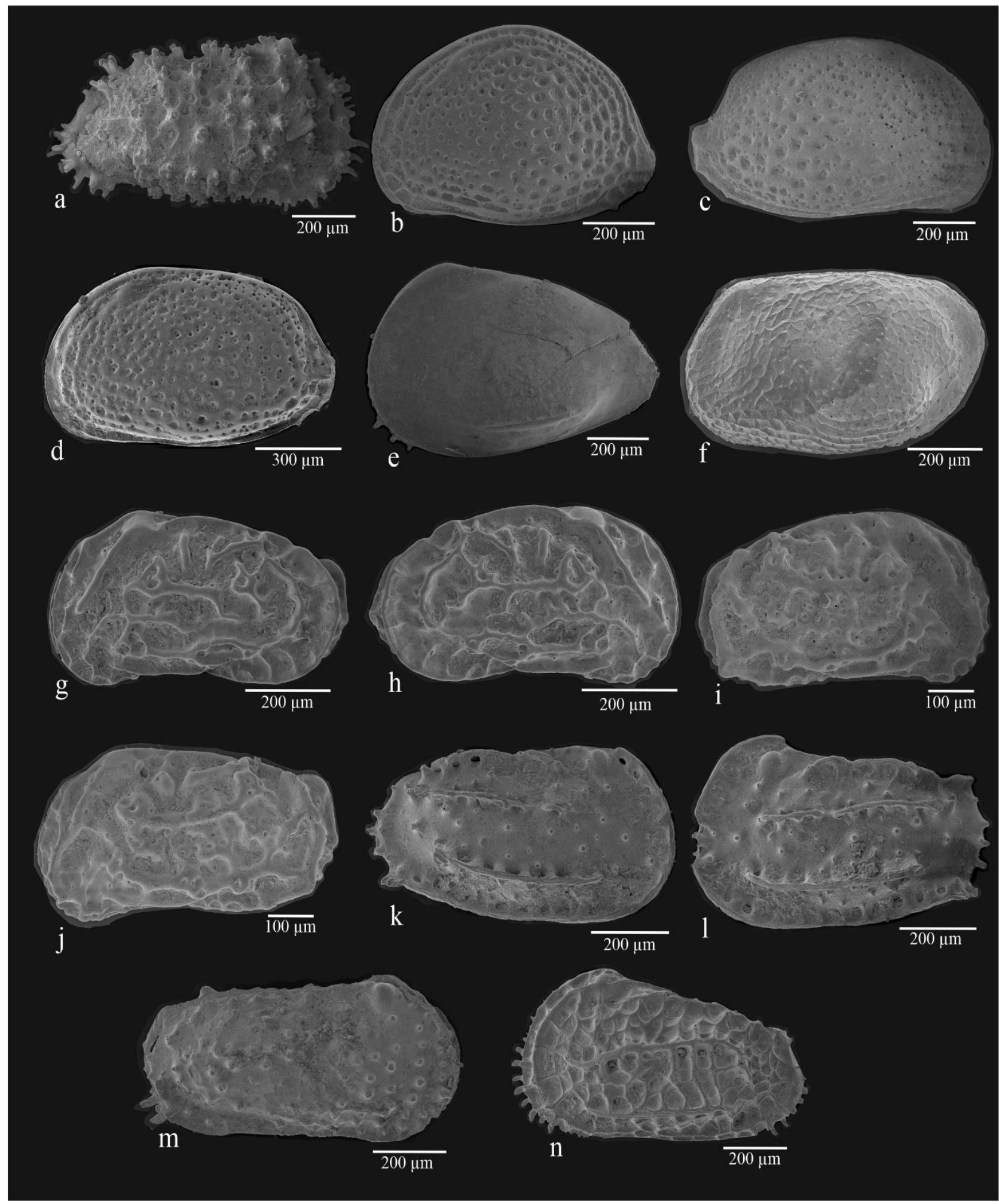

Fig. 14 Scanning electron micrographs of selected Mediterranean origin ostracod species identified from the İzmit Gulf drilling cores. a. Acanthocythereis hystrix; right valve, $205 / 1.5 \mathrm{~m}$; b-c. Aurila convexa; b left valve, 205/1.5 m, c right valve, 208/5 m; d. Aurila interpretis; left valve, 205/1.5 m; e. Bosquetina carinella; left valve, 206/33 m; f. Bythocythere minima; left valve, 201/1 m; g-h. Callistocythere intricatoides; $\mathbf{g}$ left valve, $\mathbf{h}$ right valve, 206/37.5 m; i-j. Callistocythere pallida; $\mathbf{i}$ right valve, $\mathbf{j}$ left valve, 208/5 m; k-l. Carinocythereis carinata; $\mathbf{k}$ right valve, $\mathbf{l}$ left valve, 206/37.5 m; m. Carinocythereis rhombica; right valve, 206/4.5 m; n. Costa edwardsii; left valve, 206/37.5 m. 

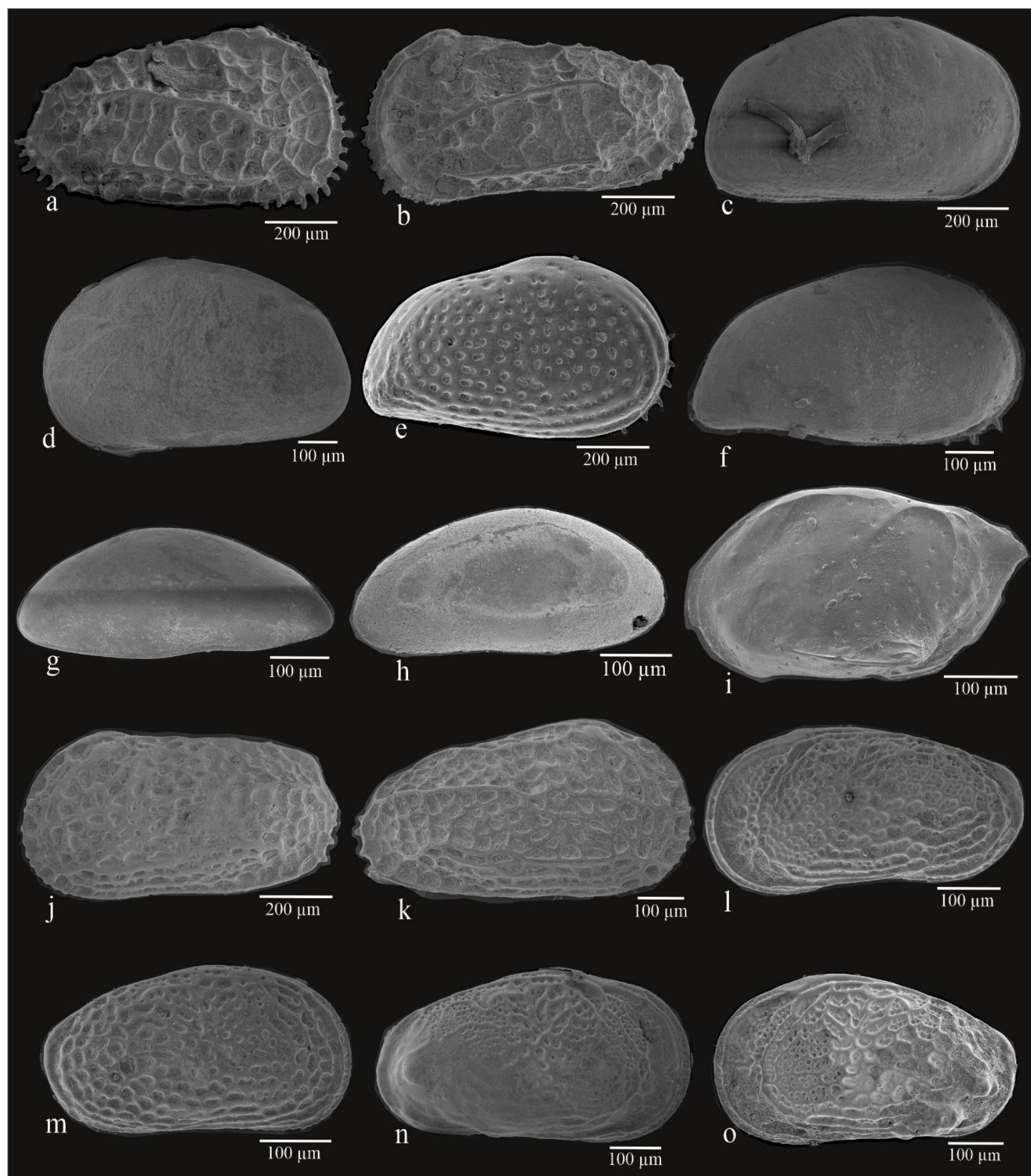

Fig. 15 Scanning electron micrographs of selected Mediterranean origin ostracod species identified from the İzmit Gulf drilling cores. a. Costa edwardsii; right valve, 206/37.5 m; b. Costa tricostata; left valve, 205/1.5 m; c-d. Cyprideis torosa; c right valve, 206/37.5 m, d left valve, 208/9 m; e-f. Cytheridea acuminata; e right valve, 208/33 m, f right valve, 207/18 m; g-h. Cytherois sp.; g right valve, 205/1.5 m. h. left valve, 201/1 m; i. Cytheropteron rotundatum, left valve, 201/1 m; j-k. Hiltermanicythere rubra; j left valve, 208/1 m; k right valve, 208/1 m; l-m. Leptocythere bacescoi, 1 left valve, $\mathbf{m}$ right valve, 206/33 m; n-o. Leptocythere bituberculata; $\mathbf{n}$ right valve, 206/37.5 m, o left valve, 207/18 m. 


$$
\text { Tamer Doğan \& Ayşegül Güney }
$$

comprised between ca. $50.0 \mathrm{ky}$ and $48.0 \mathrm{ky} \mathrm{BP}$, the Mediterranean ostracods consisting of Callistocythere pallida, Carinocythereis carinata, C. rhombica, Costa edwardsii, Cushmanidea elongata, Pontocythere turbida, Cytherois sp., Hiltermannicythere rubra, H. turbida, Leptocythere bacescoi, L. bituberculata, Loxoconcha gibberosa, Microcytherura nigrescens, Neonesidea frequens, Palmoconcha agilis, Paracytheridea parallia, Pseudocytherura calcarata, Pterygocythereis jonesii, Sagmatocythere versicolor, Semicytherura inversa, S. paradoxa, S. punctata, Urocythereis crenulasa and Xestoleberis sp. and a rich and diverse benthic foraminifera microfauna represented by the dominance of Elphidium and Ammonia genera together with subordinately numbers of $B$. aculeata, C. carinata, $H$. depressula, Bo. dilatata and As. mamilla are steadially recorded.

When all fossil findings are evaluated at early parts of MIS-3 (ca. 52.0 - 40.0 ky BP), the Marmara Sea and the Izmit Gulf as part of the Marmara Sea are connected to the Black Sea and the Mediterranean Sea. This connection is supported by global sea level curve of Chappell and Shackleton (1986) and the Surozhian transgression in the Black Sea, where the water level rises from -100 to $-25 \mathrm{~m}$ (Sorokin, 2011; Yanina, 2014). MIS-3 is an interstadial period between MIS-4 and MIS-2 glacial epochs and corresponds to regional Surozh transgression in the Black Sea and Early Khvalnian transgression in the Caspian Sea (Yanina, 2014). Faunal and floral data from the İznik Lake indicate that there was a connection with the Black Sea during the Surozhian period (30 ky-24 ky BP; Meriç et al., 2018). The incursion of the Mediterranean waters in the İzmit Gulf is stated by Meriç et al. (1995) based on the foraminifera fauna and numerical Electron Spin Resonance (ESR) ages in the time interval equivalent to MIS-3. Aksu et al. (2002) suggested that the deposition of M2 sapropel layer between $29.5 \mathrm{ky}$ and $23.5 \mathrm{ky}$ is associated with the two-layered water stratification indicating high sea level above the sill depth of the Çanakkale and İstanbul straits. The age findings obtained from the marine sediments in the south of Izmit Gulf is $36.0 \mathrm{ky}$ (Çağatay et al., 2003). On the other hand, Çağatay et al. (2015) reported that there was no connection between the Marmara Sea and Mediterranean Sea from early MIS4 to early MIS-1 or there could be a weak Mediterranean inflow limited to the deeper parts of the Marmara basin during MIS-3. Our data clearly denotes that the Izmit Gulf was connected with the Black Sea and the Mediterranean Sea at the beginning of MIS-3 and the shallow shelf areas were frequently affected by both fresh water discharges from the Black Sea and the marine inputs from the Mediterranean Sea.

\section{Holocene / MIS-1 Interval}

During MIS-2, Marmara Sea was completely isolated from the Mediterranean Sea and it is known that lacustrine environmental conditions were gone in Marmara Sea until ca. 12 ky BP (e.g., Stanley and Blanpied, 1980; Çağatay et al., 2000; Aksu et al., 2002; Yaltırak et al., 2002; Kırc1Elmas et al., 2008; McHugh et al., 2008). Its permanent two-layered water structure, where the upper layer originated from the Black Sea and the lower layer formed from the Mediterranean Sea, has established during Holocene. A thin (2 m) Holocene sediment drape occurs in the northern Dilovas1 drillings, whereas a thick $(35 \mathrm{~m})$ Holocene sedimentary sequence is retrieved from the southern Hersek Burnu drillings. Radiocarbon dates provided as $9.2 \mathrm{ky}$ at $31 \mathrm{~m}$ of 10MB-207, $8.4 \mathrm{ky}$ at $18 \mathrm{~m}$ of 10MB-206 and $6.6 \mathrm{ky}$ at $14 \mathrm{~m}$ of $10 \mathrm{MB}-208$. OSL date is $6.2 \mathrm{ky}$ at $8 \mathrm{~m}$ of 10MB-206 (Table 2). MIS-1 interval has the most diverse benthic foraminifera microfauna and the highest number of TBF. Three main benthic foraminiferal assemblages are defined within the Holocene sediments reflecting the variations in the water level. The first assemblage is dominated by Au. perlucida, A. tepida and Ammonia spp. and is recorded in the Early Holocene sediments from the base of 10MB-207 and 208. The second assemblage composed mainly of Bo. ordinaria, Bolivina spp., B. aculeata, Bulimina spp., N. turgidus and A. tepida. This relatively deeper assemblage occurs between $18-4.5 \mathrm{~m}$ of 10MB-206, $22.75-18 \mathrm{~m}$ of 10MB207, 33 - 18 m of 10MB-208. Ammonia and Elphidium characterizes the third assemblage and is represented at the upper parts of 10MB-207 and 208. The assemblage compositions show similarity with the recent benthic foraminifera microfauna in the shelf areas of the Marmara Sea (Phipps et al., 2010; K1rc1-Elmas, 2013). In recent sediments of the Marmara Sea, Ammonia and Elphidium are commonly recorded at water depths $>35 \mathrm{~m}$ and their distribution is associated with riverine organic-matter input, hydro-sedimentary processes, and the Black Sea surface inflow (K1rc1-Elmas, 2013). The Bulimina aculeata - Bolivina ordinaria (as Bolivina variabilis in Kirc1-Elmas (2013) assemblage, distributed between 28 $50 \mathrm{~m}$ depths is influenced by the inflow of vertically mixed Black Sea waters. Au. perlucida has the highest abundance at $25 \mathrm{~m}$, close to the mouth of Biga River, and is reported from slightly brackish and normal marine salinity shallow inner-shelf environments (Hayward et al., 1999). The studied ostracod and mollusc assemblages are characterized by the Mediterranean originated species. Although some Ponto-Caspian ostracods and molluscs species also appear, their occurrences in the Holocene sediments are sporadic and limited only within the EarlyMiddle Holocene. Absence or rare occurrences of the Ponto-Caspian ostracods, which are still living in the Azov Sea and the Caspian Sea, show that the water salinity in the Marmara Sea is no longer suitable for this community. 


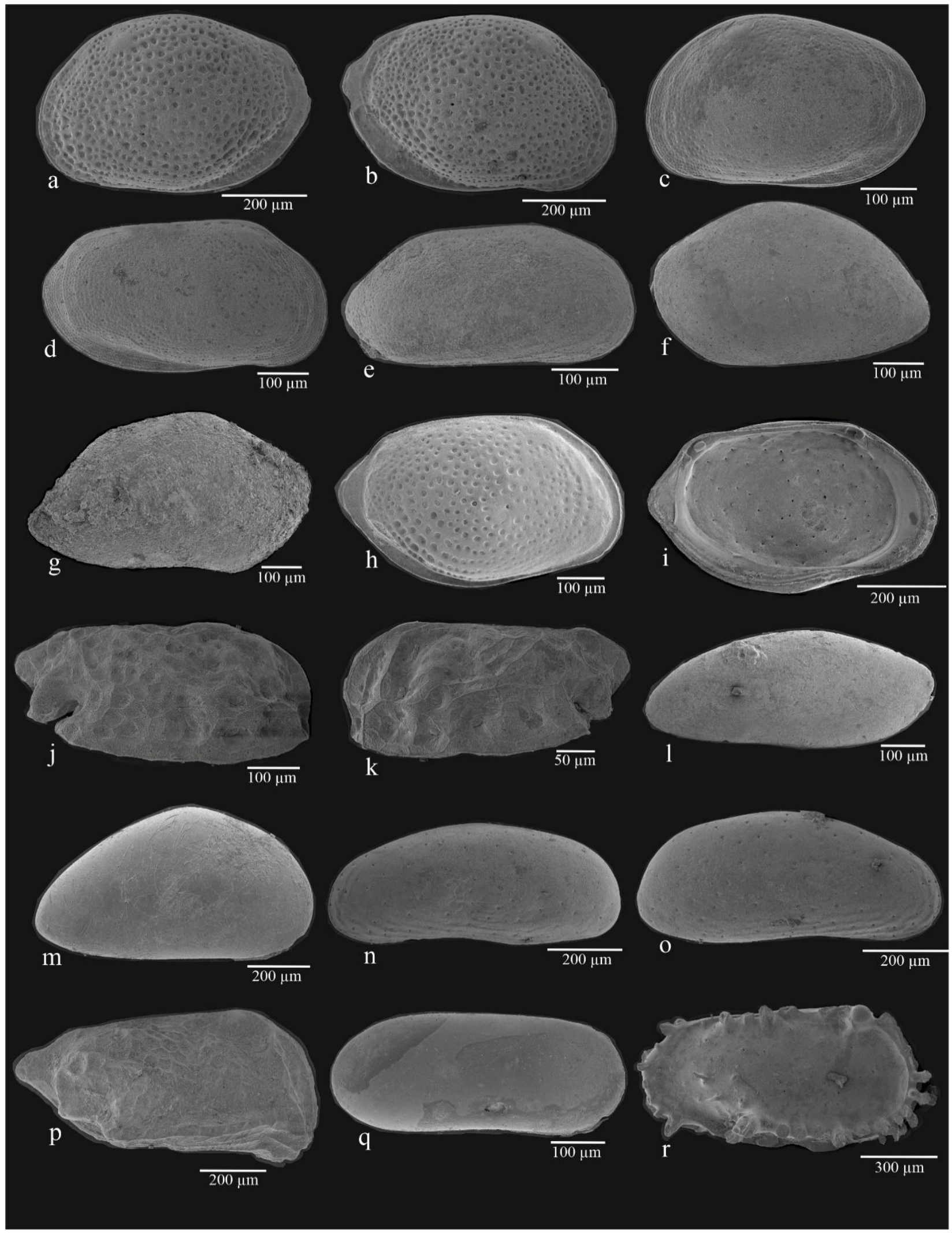

Fig. 16 Scanning electron micrographs of selected Mediterranean origin ostracod species identified from the İzmit Gulf drilling cores. a-b. Loxoconcha gibberosa; a left valve, b right valve, 206/33 m; c-d. Loxoconcha minima; $\mathbf{c}$ left valve, d right valve, 203/100 m; e. Microcytherura nigrescens; right valve, 208/2 m; f. Neonesidea frequens; left valve, 205/1.5 m; g. Neonesidea inflata; right valve, 205/10m; h-i. Palmaconcha agilis; $\mathbf{h}$ right valve, 206/33 m, i left valve internal view, 201/70 m; j-k. Paracytherida parallia; j right valve, 206/33 m, k left valve, 206/4.5 m; l. Paradoxostoma trieste, left valve, 201/1 m; m. Pontocypris rara; right valve, 201/1 m; n-o. Pontocythere turbida; $\mathbf{n}$ left valve, o right valve, 206/37.5 m; p. Pseudocytherura calcarata, right valve, 208/2 m; q. Pseudopsammocythere reniformis, right valve, 205/1.5 m; r. Pterygocythereis jonesii, right valve, 206/37.5 m. 


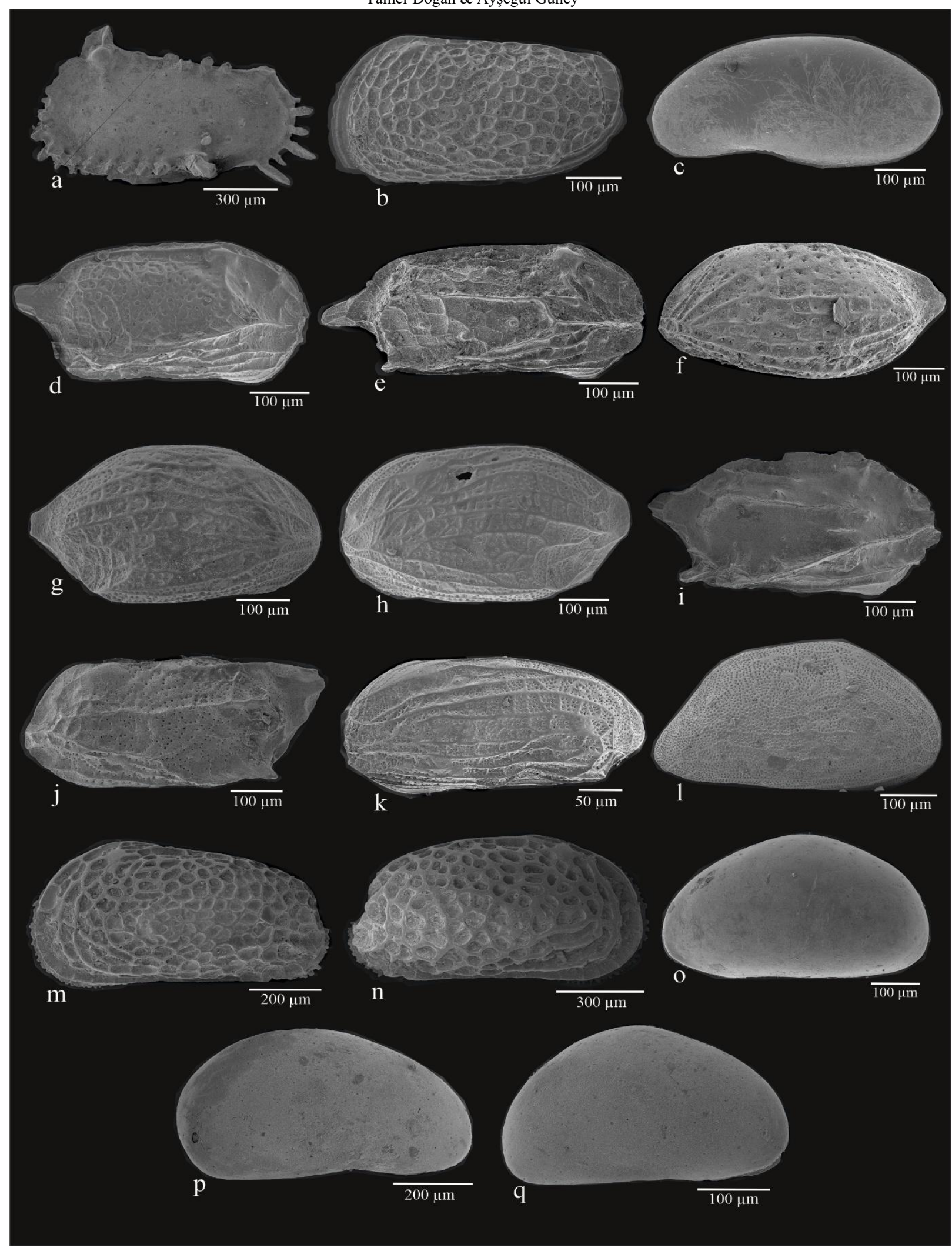

Fig. 17 Scanning electron micrographs of selected Mediterranean origin ostracod species identified from the İzmit Gulf drilling cores. a. Pterygocythereis jonesii; left valve, $208 / 2 \mathrm{~m}$; b. Sagmatocythere versicolor; left valve, 206/33 m; c. Sclerochilus contortus; left valve, 208/14 m; d. Semicytherura alifera; right valve, 201/1 m; e. Semicytherura diafora; right valve, 208/18 m; f. Semicytherura incongruens; left valve, 208/2 m; g-h. Semicytherura inversa; g right valve, 208/9 m, h left valve, 208/5 m; i. Semicytherura paradoxa; right valve, 206/37.5 m; j. Semicytherura punctata; left valve, 206/37.5m; k. Semicytherura sulcata; left valve, 203/100 m; l. Tetracytherura irregularis; right valve, 205/1.5 m; m-n. Urocythereis crenulosa; $\mathrm{m}$ left valve, $\mathrm{n}$ right valve, 206/33 m; o-p. Xestoleberis depressa; p left valve, q right valve, 206/33 m; r. Xestoleberis communis; right valve, 206/4.5 m. 


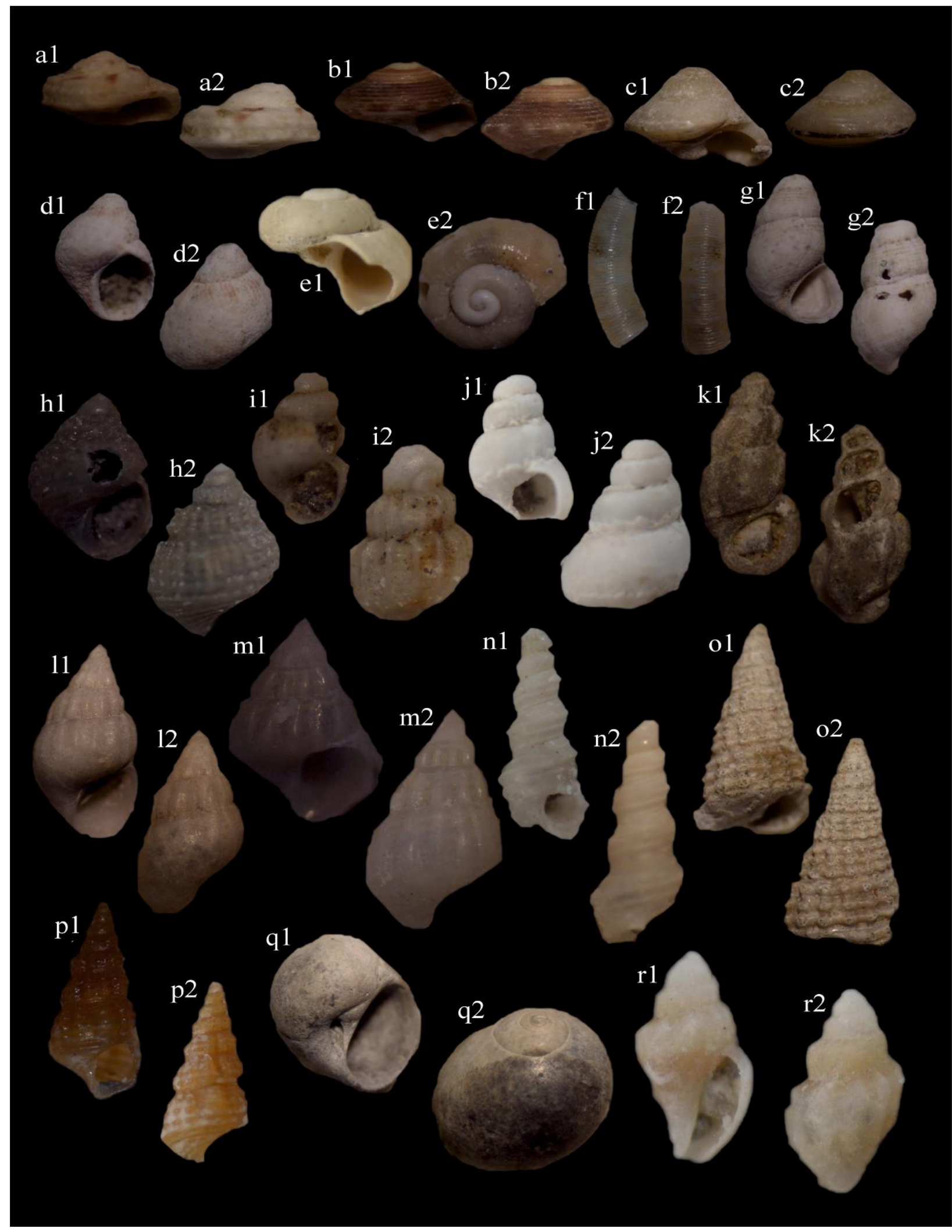

Fig. 18 Photographs of selected gastropod species identified from the İzmit Gulf drillings. a1, a2. Gibbula albida, height: $2 \mathrm{~mm}$, 207/5 m. b1, b2. Gibbula varia, height: 1 mm, 208/5 m. c1, c2. Gibbula sp., height: 3.5 mm, 208/5 m. d1, d2. Tricolia pullus, height: 2 mm, 207/1 m. e1, e2. Omalogyra atomus, height: 1 mm, 205/14 m. f1, f2. Caecum trachea, height: 2 mm, 207/13 m. g1, g2. Alvania abbysicola, height: $2 \mathrm{~mm}, 205 / 10 \mathrm{~m}$. h1, h2. Alvania cimex, height: $2 \mathrm{~mm}, 206 / 41 \mathrm{~m}$. i1, i2. Alvania sp., height: $1 \mathrm{~mm}$, 206/41 m. j1, j2. Cingula sp., height: 3 mm, 205/14 m. k1, k2. Monzonia crassa, height: 3 mm, 207/1 m. 11, 12. Rissoa marginata, height: 5 mm, 207/13 m. m1, m2. Rissoa pulchella, height: 2.5 mm, 207/13 m. n1, n2. Turritella sp., height: $1.5 \mathrm{~mm}, 207 / 9 \mathrm{~m}$. o1, o2. Pirenella conica, height: $3.5 \mathrm{~mm}, 205 / 1.5 \mathrm{~m}$. p1, p2. Bittium latreilli, height: $2 \mathrm{~mm}, 207 / 13$ m. q1, q2. Natica rizzae, height: 5 mm, 206/41 m. r1, r2. Trophon sp., height: $2 \mathrm{~mm}$, 207/5 m. 


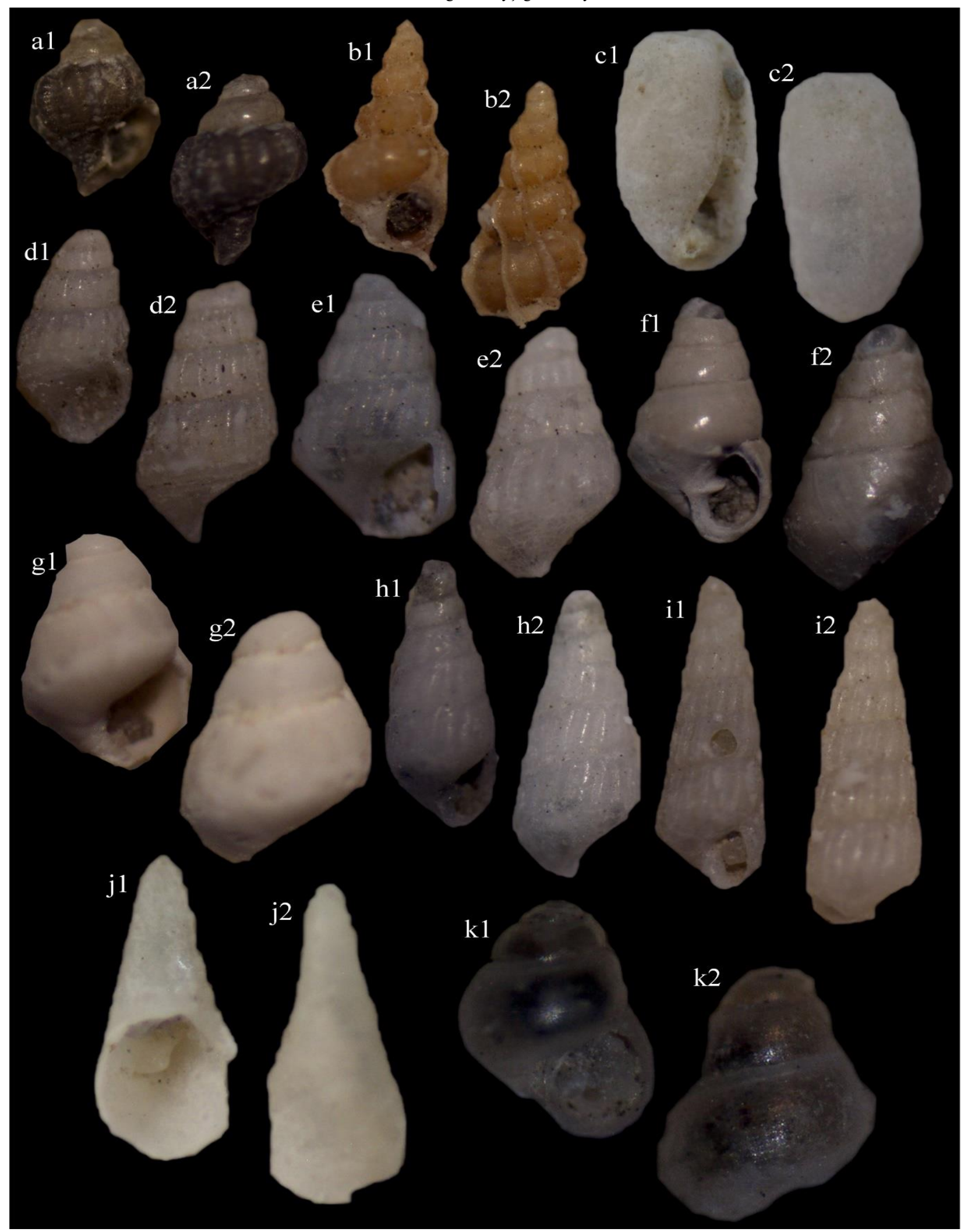

Fig. 19 Photographs of selected gastropod species identified from the İzmit Gulf drillings. a1, a2. Nassarius sp., height: $1.5 \mathrm{~mm}$, 207/13m. b1, b2. Opalia crenata, height: 2.5 mm, 207/13 m. c1, c2. Retusa umbilicata, height: 2.5 mm, 207/9 m. d1, d2. Chrysallida indistincta, height: $1 \mathrm{~mm}, 207 / 9$ m. e1, e2. Chrysallida obtusa, height: $1.5 \mathrm{~mm}, 207 / 13 \mathrm{~m}$. f1, f2. Odostomia acuta, height: $1.5 \mathrm{~mm}$, 206/41m. g1, g2. Odostomia sp., height: 1mm, 207/26 m. h1-h2, i1-i2. Turbonilla lactea, height: 2 mm, 207/13 m. and hight: 2.5 mm, 208/5 m. j1, j2. Creseis virgua, height: 1 mm, 208/5m. k1, k2. Bythinella pannonica, height: 2 mm, 201/81 m. 


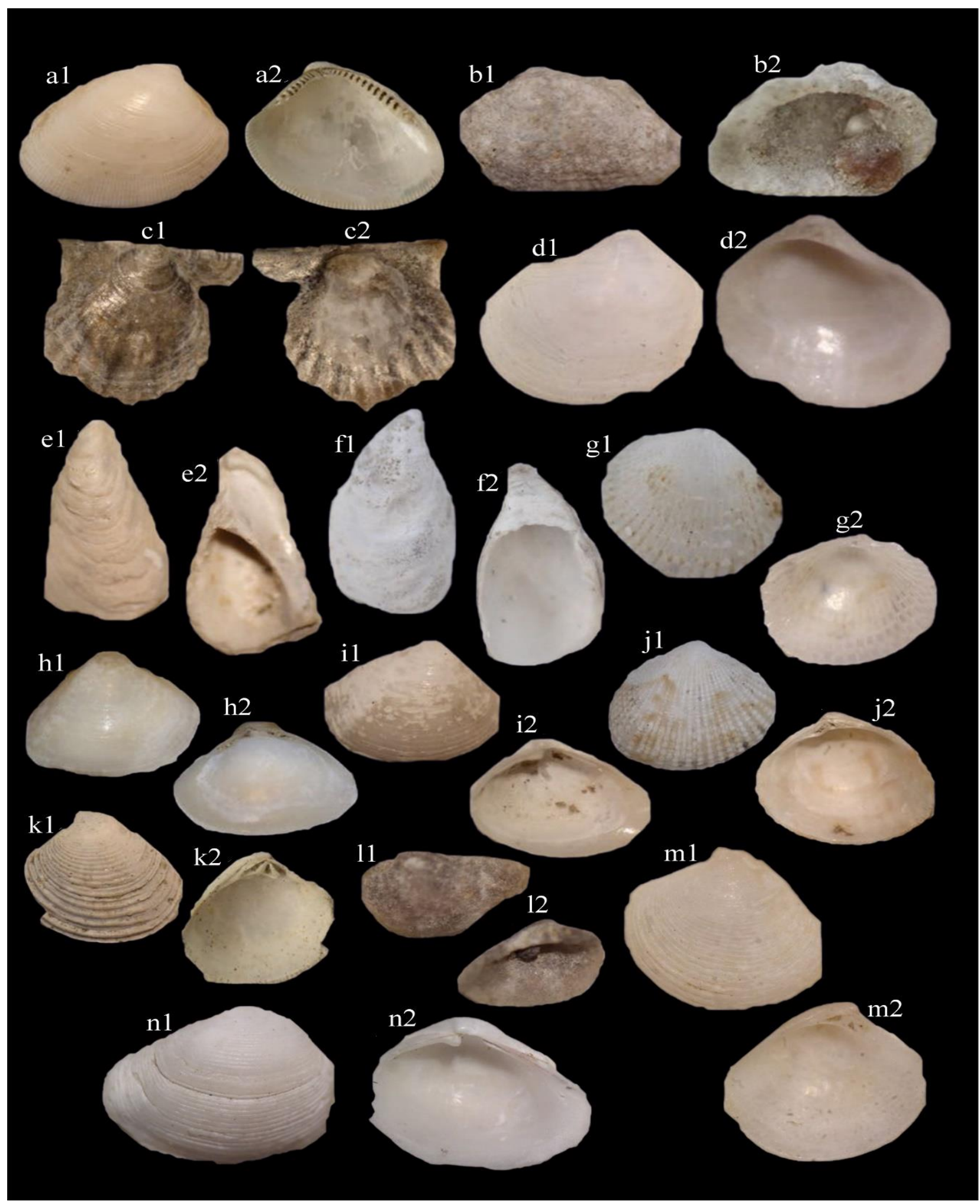

Fig. 20 Photographs of selected bivalvia species identified from the İzmit Gulf drillings. a1, a2. Nucula nucleus, height: $5 \mathrm{~mm}$, 208/1 m. b1, b2. Anadara diluvi, height: 2 mm, 207/9 m. c1, c2. Chlamys glabra, height: 2 mm, 208/9 m. d1, d2. Lucinella divaricata, height: $1.5 \mathrm{~mm}, 208 / 5 \mathrm{~m}$. e1, e2. Dreissena rostriformis distincta, height: $4 \mathrm{~mm}, 207 / 26 \mathrm{~m}$. f1, f2. Dreissena rostriformis tschaudae, height: 3mm, 204/13 m. g1, g2. Parvicardium exiguum, height: 2 mm, 201/1 m. h1, h2. Spisula subtruncata, height: 7 mm, 207/1 m. i1, i2. Lentidium mediterraneum, height: 3mm, 208/9 m. j1, j2. Timoclea ovata, height: 6 mm, $205 / 1.5$ m. k1, k2. Clausinella fascita, height: 3 mm, 208/1 m. 11, 12. Clausinella sp., height: 2 mm, 207/1 m. m1, m2. Gouldia minima, height: 2 mm, 208/5 m. n1, n2. Corbula gibba, height: 4 mm, 207/1 m. 


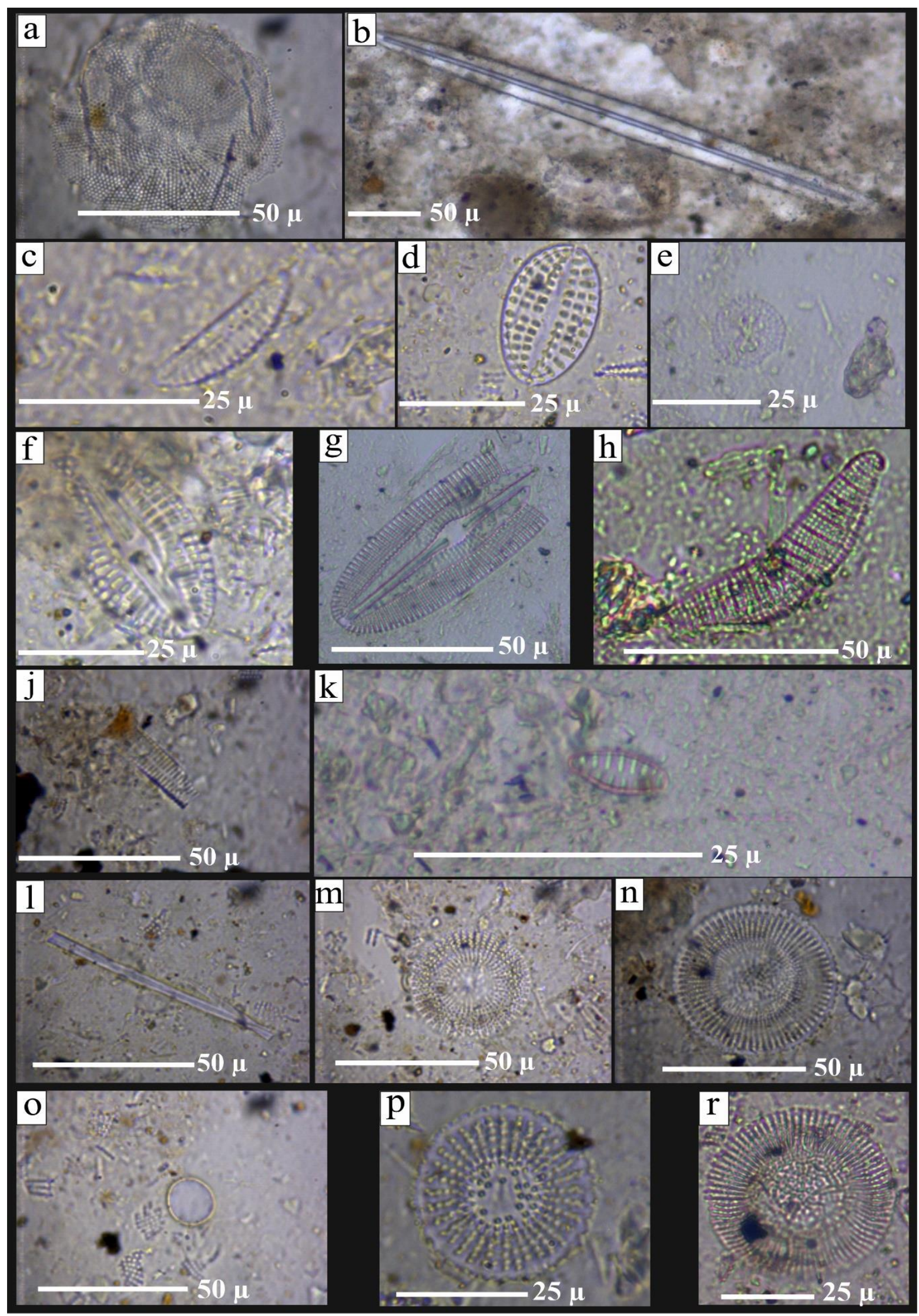

Fig. 21 Microphotographs of diatom taxa identified from drilling 10MB-203. a. Actinocyclus normanii, 95 m. b. Amphipleura pellucida, 95 m. c. Amphora libyca, 143.5 m. d. Cocconeis disculus, 95 m. e. Cyclotella comensis, 143.5 m. f. Diploneis elliptica, 95 m. g. Diploneis parma, 143.5 m. h. Epithemia turgida var. westermannii, 143.5 m. j. Fragilaria sp, 95 m. k. Fragilaria lancettula, 143.5 m. l. Stenopterobia sigmatella, 95 m. m. Stephanodiscus aegyptiacus, 95 m. n. Stephanodiscus alpinus, 95 m. o. Stephanodiscus lucens, 95 m. p. Stephanodiscus medius, 95 m. r. Stephanodiscus niagarae, 95 m. 


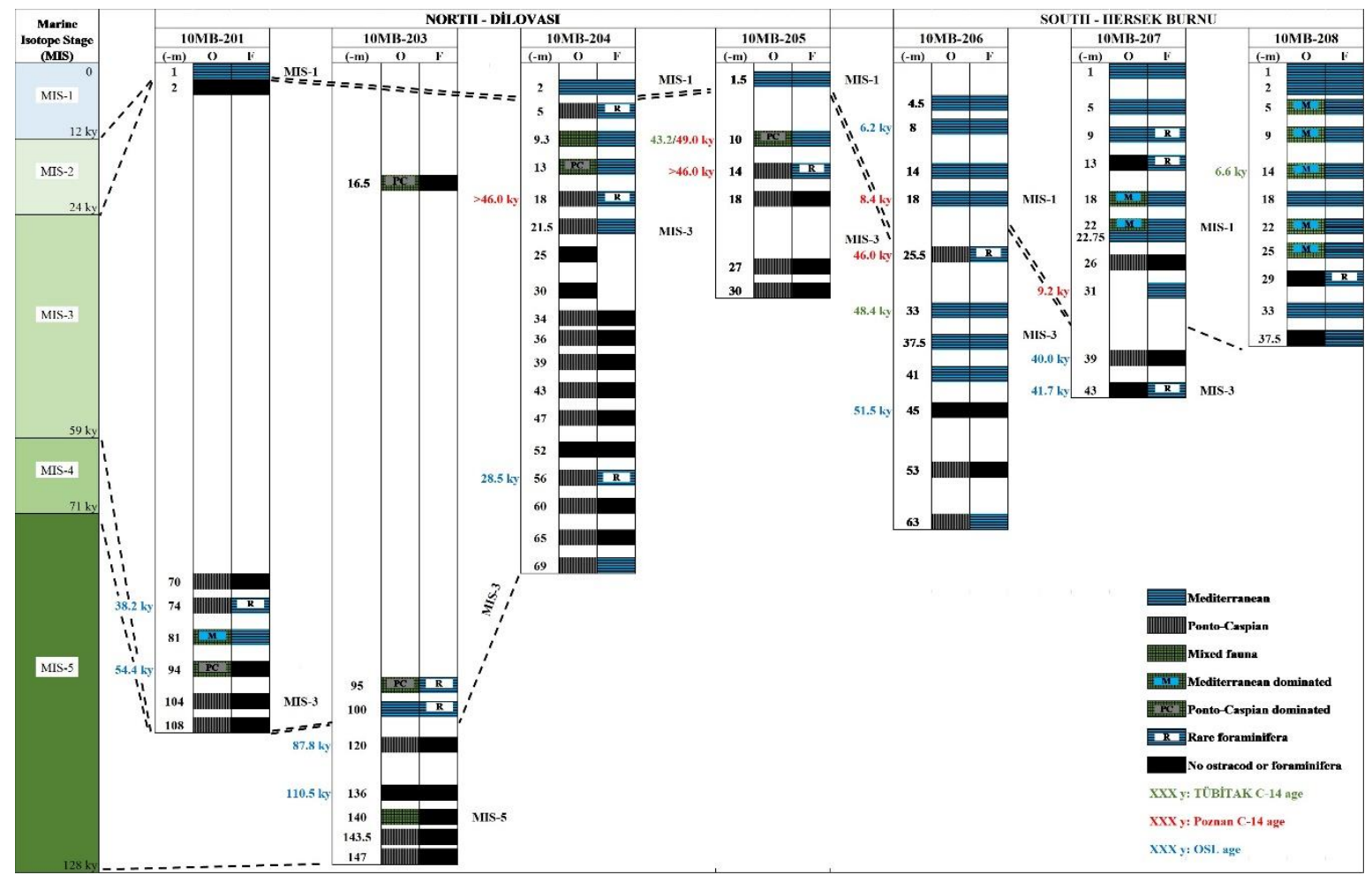

Fig. 22 Chronostratigraphic and faunal correlation of the İzmit Gulf drillings. The radiocarbon dates are expressed as uncalibrated (boundary of marine isotope stages from Imbre et al., 1984). The lower intervals of drillings 10MB-204 (120-80 m), 10MB-205 (117.2-40 m), 10MB-206 (122-80 m), 10MB-207 (120.9-50 m) and 10MB-208 (200-40 m) are not shown due to absence of sample.

\section{ACKNOWLEDGEMENTS}

This research was supported by the Scientific Research Projects Unit of Çukurova University (Project numbers: FBA-2017-8380 and FYL-2018-11273). We are grateful to the Senior Geology Engineerings Behiç ÇONGAR and Niyazi ŞENNAZLI from "Fugro Sial Earth Sciences Consultancy and Engineering Ltd." for the studied samples of drillings. Prof.Dr. Namık YALÇIN (İ.Ü.) provided us helpful suggestions and improved the manuscript. In addition, the authors would like to thank to the Çukurova University Central Laboratory Management and Expert Deniz TAKLI for taking of Scanning Electron Microscope photographs. We are grateful to anonymus reviewer and Simina Dumitriu (Romania) for their critical comments and suggestions, which improved the manuscript. Also, we are grateful to Dr. John Ryan for his assistance in the revision of the English version of this manuscript.

\section{REFERENCES}

Aitken, M.J., 1998. An Introduction to Optical Dating. The Dating of Quaternary Sediments by the use of Photonstimulated Luminescence, Oxford University Press, 1267.

Aksu, A.E., Hiscott, R.N. \& Yaşar, D., 1999. Oscillating uaternary water levels of the Marmara Sea and vigorous out- fow into the Aegean Sea from the Marmara Sea-Black Sea drainage corridor. Marine Geology, 153: 275-302.

Aksu, A.E., Hiscott, R.N., Kaminski, M.A., Mudie, P,J., Gillespie, H., Abrajano, T. \& Yaşar, D., 2002. Last glacial-Holocene paleoceanography of the Black Sea and Marmara Sea: stable isotopic, foraminiferal and coccolith evidence. Marine Geology, 190: 119-149.

Ardel, A. \& İnandık, H., 1957. Berzah of Kapıdağ Peninsula (Belkıs Tombolo). İstanbul Üniversitesi Coğrafya Enstitüsü Dergisi, 8:65-66 [in Turkish].

Athersuch, J., Horne, D.J. \& Whittaker, J.E., 1989. Marine and brackish water ostracods. Synopses of the British Fauna (New Series), E.J.Brill, 43: 1-343.

Badertscher, S., Fleitmann, D., Cheng, H., Edwards, R.L., Göktürk, O.M., Zumbühl A., Leuenberger, M. \& Tüysüz, O., 2011. Pleistocene water intrusions from the Mediterranean and Caspian seas into the Black Sea. Nature Geoscience, 4: 236-239.

Bernt, C., Yıldırım, C., Çiner A., Strecker, M.R., Ertunç, G., Sarıkaya, M.A., Özcan, O., Ozturk, T. \& Kiyak N.G., 2018. Quaternary uplift of the northern margin of the Central Anatolian Plateau: New OSL dates of fluvial and delta-terrace deposits of the Kizilirmak River, Black Sea coast, Turkey. Quaternary Science Reviews, 201, 446-469.

Beşiktepe, Ş.T., Sur, H.İ., Özsoy, E., Latif, M.A., Oğuz, T. \& Ünlüata, Ü., 1994. The circulation and hydrography 


\section{Tamer Doğan \& Ayşegül Güney}

of the Marmara Sea. Progress in Oceanography, 34:285-334

Bonaduce, G., Ciampo, G. \& Masoli, M., 1975. Distribution of ostracoda in the Adriatic Sea. Pubblicazioni della Stazione Zoologica di Napoli 40 (Suppl.): 1-304.

Boomer, I., Guichard, F. \& Lericolais, G., 2010. Late Pleistocene to recent ostracod assemblages from the western Black Sea. Journal of Micropaleontology, 29: 119-133.

Boomer, I., von Grafenstein, U., Guichard, F. \& Bieda, S., 2005. Modern and Holocene sublittoral ostracod assemblage (Crustacea) from the Caspian Sea: a unique brackish, deep-water environment. Palaeogeography, Palaeoclimatology, Palaeoecology, 225: 173-186.

Breman, E., 1975. The Distribution of Ostracodes in the Bottom Sediments of the Adriatic Sea. Vrije Universiteit te Amsterdam, Krips Repro, Meppel, 165 pp.

Briceag, A., Stoica, M., Oaie, G. \& Melinte-Dobrinescu, M.C., 2012. Late Holocene microfaunal and nannofloral assemblages of the NW Black Sea. GeoEco-Marina, 18: 65-73.

Büyükmeriç, Y., 2016. Postglacial floodings of the Marmara Sea: molluscs and sediments tell the story. Geo-Marine Letters, 36: 307-321.

Chappell, J. \& Shackleton, N.J., 1986. Oxygen isotopes and sea level. Nature, 324:137-140.

Cimerman, F. \& Langer, R.L., 1991. Mediterranean Foraminifera: Slovenska Akademija Znanosti in Umetnosti, Academia Scientiarum et Artium Slovenica, Ljubljana, 118 pp.

Çağatay, M.N., Görür, N., Algan, O., Eastoe, C., Tchapalyga, A., Ongan, D., Kuhn, T. \& Kuşcu, İ., 2000. Late Glacial-Holocene palaeoceanography of the Sea of Marmara: timing of connections with the Mediterranean and Black seas. Marine Geology, 167: 191-206.

Çağatay, M.N., Görür, N., Polonia, A., Demirbağ, E., Sakınç, M., Cormier, M.H., Copotondi, L., McHugh, C., Emre, Ö. \& Eriş, K., 2003. Sea-level changes and depositional environments in the İzmit Gulf, eastern Marmara Sea, during the late glacial-Holocene period. Marine Geology, 202: 159-173.

Çağatay, M.N., Eriş, K., Ryan, W.B.F., Sancar, Ü., Polonia, A., Akçer, S., Biltekin, D., Gasperini, L., Görür, N., Lericolais, G. \& Bard, E., 2009. Late Pleistocene-Holocene evolution of the northern shelf of the Sea of Marmara. Marine Geology, 265: 87-100.

Çağatay, M.N., Wulf, S., Ümmühan, S., Özmaral, A., Vidal, L., Henry, P., Appelt, O. \& Gasperini, L., 2015. The tephra record from the Sea of Marmara for the last ca. $70 \mathrm{ka}$ and its palaeoceanographic implications. Marine Geology, 361: 96-110.

Çetin, O., Çetin, T. \& Ukav, İ., 1995. Electron spin resonance (ESR) dating of fossil mollusc shells observed in Quaternary sequence in the Gulf of İzmit
(Hersek Burnu-Kaba Burun). In: Meriç, E. (ed.) İzmit Körfezi Kuvaterner İstifi. 269-275 [in Turkish].

Doğan, T., Çetin, H., Yeğingil, Z., Topaksu, M., Yüksel, M., Duygun F., Nur, N. \& Yeğingil, İ., 2015. Optically stimulated luminescence dating of Holocene alluvial fans, East Anatolian Fault System, Turkey. Radiation Effects and Defects in Solids, 170: 630-644.

Eriş, K.K., Çağatay, M.N., Akçer Ön, S., Casperini, L. \& Mart, Y., 2011. Late glacial to Holocene sea-level changes in the Sea of Marmara: new evidence from high-resolution seismics and core studies. Geo-Marine Letters, 31: 1-18.

Guillaume, M.C., Peypouquet, J.P. \& Tetart, J., 1985. Quaternaire et actuel. Atlas des Ostracodes de France. Oertli, H.J. (ed.). Bulletin Centres Rechearche Exploration Proceeding Elf-Aquitaine Mémoire, 9: 337-377.

Hartmann, G. \& Puri, S.H., 1974. Summary of neontological and paleontotogical classification of ostracoda. Mitteilungen aus dem Zoologischen Staatsinstitut und Zoologischem Museum in Hamburg, 70: 7-73.

Hayward, B.W., Grenfeld, H.R., Reid, C.M. \& Hayward, K.A., 1999. Recent New Zealand Shallow-Water Benthic Foraminifera: Taxonomy, Ecologic Distribution, Biogeography, and Use in Paleoenvironmental Assessments: Institute of Geological and Nuclear Sciences Limited, Lower Hutt, New Zealand, 264 pp.

Huntley, D.J., 1985. On the zeroing of the thermoluminescence of sediments. Physics and Chemistry of Minerals, 12: 122-127.

Huntley, D.J., Godfrey-Smith, D.I. \& Tewalt M.L.W., 1985. Optical Dating of Sediments. Nature, 313: 105107.

Imbrie, J., Hays, J.D., Martinson, D.G., McIntyre, A., Mix, A.C., Morley, J.J., Pisias, N.G., Prell, W.L. \& Shackleton, N.J., 1984. The orbital theory of Pleistocene climate: support from a revised chronology of the marine $\delta 180$ record. In: Berger, A., Imbrie, J., Hays, J., Kukla, G. \& Saltzman, B. (eds), Milankovitch and Climate, Part 1. Reidel, Dordrecht, pp. 269-305.

Ivanova, E.V., Marret, F., Zenina, M.A., Murdmaa, I.O., Tchepalyga, A.L., Bradley, L.R., Schornikov, E.I., Levchenko, O.V. \& Zyryanova, M.I., 2015. The Holocene Black Sea reconnection toy he Mediterranean Sea: New insights from the northeastern Caucasian shelf. Palaeogeography, Palaeoclimatology, Palaeoecology, 427: 41-61.

İslamoğlu, Y. \& Tchepalyga, A.L., 1998. The environmental changes determined with Molluscan assemblages during the Neoeuxinian-Holocene stages in the Sea of Marmara. Geological Bulletin of Turkey, 41 (1): 55-62 [in Turkish].

Javadova, A., 2019. Quaternary deposits and ostracod fauna in the South Caspian and adjacent areas: Azerbaijan Society of Petroleum Geologists. Books on Demand, Norderstedt, 127pp. 
Joachim, C. \& Langer, M.R., 2008. The 80 most common Ostracods from the Bay of Fetovaia Elba Island (Mediterranean Sea). Universität Bonn, 29 p.

Juyal, N., Chamyal, L. S., Bhandari, S., Bhushan, R., Singhvi, A. K., 2006. Continental record of the southwest monsoon during the last $130 \mathrm{ka}$ : evidence from the southern margin of the Thar Desert, India. Quaternary Science Reviews, 25, 2632-2650.

Kaminski, M.A., Aksu, A.E., Box, M., Hiscott, R.N., Filipescu, S. \& Al-Salameen, M., 2002. Late glacial to Holocene benthic foraminifera in the Marmara Sea: implications for Black Sea-Mediterranean Sea connections following the last deglaciation. Marine Geology, 190: 165-202.

Kapan Yeşilyurt, S., Taner, G. \& İslamoğlu, Y., 1997. Quaternary molluscan fauna of the Marmara Sea (Turkey). Yerbilimleri Dergisi (Geousound), 30(1): 217-227 [in Turkish].

Kerey, E., Meriç, E., Kapan Yeşilyurt, S., Nazik, A., Tunoğlu, C., Avşar, N., Akgün, F., Uludağ, M., Agasi, N., Tıraş, M., Çil, E. \& Akkiraz, M.S., 2004. The aspects of the Late Quaternary (Holocene) setting belong to the eastern Gulf of Izmit, Adapazary, the delta of Sakarya and their environments. Bulletin of Earth Sciences Application and Research Centre of Hacettepe University, 29: 55-76 [in Turkish].

Ketin, İ., 1948. Über die tektonisch-mechanischen Folgerungen aus den Grossen Anatolischen Erdbeben des Letzten Dezenniums. Geologische Rundschau, 36: 77-83.

Kirc1-Elmas, E., 2013. Benthic foraminiferal distribution (living and dead) from a permanently stratified marginal sea (Marmara Sea, Turkey). Journal of Foraminiferal Research, 43 (4): 340-360.

Kirc1-Elmas, E., Algan, O., Özkar-Öngen, İ., Struck, U., Altenbach, A.V., Sagular, E.K. \& Nazik, A., 2008. Palaeoenvironmental investigation of sapropelic sediments from the Marmara Sea: A biostratigraphic approach to palaeoceanographic history during the last Glacial-Holocene. Turkish Journal of Earth Sciences, 17: 129-168.

Kistenich, S., Zimmermann, J. \& Dreßler, M., 2014. An investigation into the morphology and genetics of Cyclotella comensis and closely related taxa. Diatom Research, 29 (4): 423-440. doi: 10.1080/0269249X.2014.922125.

Krammer, K. \& Lange-Bertalot, H., 1986. 1. Teil, band 2/1, Gustav Fischer Verlag Stuttgart. New York.

Krammer, K. \& Lange-Bertalot, H., 1986. 3. Teil, band 2/3, Gustav Fischer Verlag Stuttgart. New York.

Krammer, K. \& Lange-Bertalot, H., 1988. 2 Teil, band 2/2, Gustav Fischer Verlag Stuttgart. New York.

Krammer, K. \& Lange-Bertalot, H., 1991. 4. Teil, band 2/4, Gustav Fischer Verlag Stuttgart. New York.

Kurt, H. \& Yücesoy, E., 2009. Submarine structures in the Gulf of İzmit, based on multichannel seismic reflection and multibeam bathymetry. Marine Geophysical Research, 30: 73-84.
Lowe, J.J. \& Walker, M.J.C., 1984. Reconstructing Quaternary Environments: Longman Group Limited, London, 389 pp.

"MarBEF Data System" (http://www.marbef.org/data/)

Major, C., Ryan, W., Lericolais, G. \& Hajdas, I., 2002. Constraints on Black Sea out low to the Sea of Marmara during the last glacial-interglacial transition. Marine Geology, 190, 19-34.

McHugh, C.M.G., Gurung, D., Giosan, L., Ryan, W.B.F., Mart, Y., Sancar, U., Burckle, L. \& Çağatay, M.N., 2008. The last reconnection of the MarmaraSea (Turkey) to the World Ocean: paleoceanographic and paleoclimatic perspective. Marine Geology, 255: 6482.

Meriç, E., 1995a. Quaternary sequence in the Gulf of Izmit. Kocaeli Valiliği Çevre Koruma Vakfı İstanbul, s. 354 [in Turkish].

Meriç, E., 1995b. Evidence for inter-connection between the Sea of Marmara and Black Sea via Gulf of IzmitLake Spanca and the Sakarya Valley prior to the Bosporus. In: Meriç, E.(Ed.), Izmit Korfezi Kuvaterner Istifi (Quaternary Sequence in the Gulf of Izmit). Kocaeli Valiligi Cevre Koruma Vakfi Istanbul, pp. 295-301 [in Turkish].

Meriç, E., Avşar, N. \& Bergin, F., 2004. Benthic Foraminifera of Eastern Aegean Sea (Turkey) Systematics and Autoecology: Turkish Marine Research Foundation, İstanbul, 306 pp.

Meriç, E., Kerey, İ.E., Tunoğlu, C., Taner, G., Kapan Yeşilyurt, S., Ünsal, İ. \& Rosso, A.D., 2000. New Findings on the Late Quaternary (Holocene) Marmara Sea-Black Sea connection via the Bosphorus Sea way. Geological Bulletin of Turkey, 43 (1): 73-118 [in Turkish].

Meriç, E., Avşar, N., Nazik, A., Alpar, B., Yokeş, B., Barut, İ.F. \& Ünlü, S., 2005. Foraminifer, ostracod and mollusc fauna of the Gulf of Gemlik; morphological anomalies observed in foraminifer tests, sedimentological, hidrochemical and biochemical characteristics of the region. Bulletin of The Mineral Research and Exploration, 131: 21-48.

Meriç, E., Nazik, A., Avşar, N., Alpar, B, Ünlü, S. \& Gökaşan, E., 2009. Evidences of a possible Marmara Sea- Iznik Lake connection in Quaternary: Determination of ostracods and Foraminifers in the Recent sediments of the Iznık Lake (Bursa - NW Turkey). İ. Ü. Yerbilimleri Dergisi, 22 (1), 1-19 [in Turkish].

Meriç, E., Nazik, A., Yümün, Z.Ü., Büyükmeriç, Y., Avşar, N., Yıldız, A., Sagular, E.K., Koral, H. \& Gökaşan, E., 2018. Fauna and flora of drilling and core data from the İznik Lake: The Marmara and the Black Sea connection. Quaternary International, 486: 156184. doi: 10.1016/j.quaint.2017.08.067.

McHugh, C.M.G., Gurung, D., Giosan, L., Ryan, W.B.F., Mart, Y., Sancar, Ü., Burckle, L. \& Çağatay, M.N., 2008. The last reconnection of the Marmara Sea (Turkey) to the World Ocean: A paleoceanographic 
and paleoclimatic perspective. Marine Geology, 255: 64-82.

Mostafawi, N. \& Matzke-Karasz, R., 2006. Pliocene Ostracoda of Cephalonia, Greece - the unrevised species of Uliczny (1969). Revista Española de Micropaleontología, 38 (1): 11-48.

Murray, A.S., \& Wintle, A.G., 1998. Factors Controlling the Shape of the OSL Decay Curve in Quartz. Radiation Measurements, 29: 65-79.

Murray, J.W., 1973. Distribution and Ecology of Living Benthic Foraminiferids: Heineman, London, 288 pp.

Murray, J.W., 1991. Ecology and distribution of benthic foraminifera, in Lee, J.J. \& Anderson, O.R. (eds.), Biology of Foraminifera: Academic Press, London, p. 221-253.

Nazik, A., Meriç, E., Avşar, N., Ünlü, S., Esenli, V. \& Gökaşan, E., 2011. Possible waterways between the Marmara Sea and the Black Sea in the late Quaternary: evidence from ostracod and foraminifer assemblages in lakes İznik and Sapanca. Geo-Marine Letters, 31 (2), 75-86.

Nazik, A., Meriç, E. \& Avşar, N., 2012. Reply to discussion: a critique of possible waterways between the Marmara Sea and the Black Sea in the late Quaternary: evidence from ostracod and foraminifer assemblages in lakes İznik and Sapanca, Turkey. GeoMarine Letters, 32, 275-277.

Neveskaja, I., 1963. Bestimmungstabella zweiklappiger mollusken mariner Quartarsedimentedes Schwarzmeerbeckens. Akademie der Wissenschaften SSSR Arbeiten des Palaontologischen Institutes Bd.96, Moscow, $211 \mathrm{pp}$.

Olteanu, R., 1978. Ostracoda from DSDP Leg 42B. In: Usher, J.L. \& Supko, P. (eds) Initial reports of the Deep-Sea Drilling Project, 42 (2): 1017-1038.

Olteanu, R., 2003-2004. Black Sea Transgressions During the Late Holocene. GeoEcoMarina, 9-10: 1-5.

Opreanu, P.A., 2008. Ostracode relicte Ponto-Caspice in sectorul Romanecs Aal Marii Negre. GeoEcoMarina, 14: 57-62.

Pala (Toprak), G. \& Çağlar, M., 2006. Keban Baraj Gölü Epilitik Diyatomeleri ve Mevsimsel Değişimleri, Fırat Üniversitesi Mühendislik Bilimleri Dergisi, 18(3): 323-329.

Pfannenstiel, M., 1944. Die diluvialen Entwicklungsstadien und die Urgeschichte von Dardanellen, Marmarameer und Bosporus Geologische Rundschau 34:342-433.

Phipps, M.D., Kaminski M.A. \& Aksu A.E., 2010. Calcareous benthic foraminiferal biofacies along a depth transect on the southwestern Marmara shelf (Turkey): Micropaleontology, 56: 377-392.

Poppe, G. \& Goto, Y., 1991. European Seashells (Polyplacophora, Caudofoveata, Solenogastra, Gastropoda), I, 352 pp.

Poppe, G. \& Goto, Y., 1993. European Seashells (Scaphopoda, Bivalvia, Cephalopoda), Volume II, 220 pp.
Round, F.E., 1956. The phytoplankton of three water supply reservoirs in central Wales. Arch. F. Hydrobiology, 52: 457-469.

Round, F.E., 1984. The Ecology of the Algae Cambridge University Pres, $633 \mathrm{p}$.

Round, F.E., Crawford, R.M. \& Mann, D.G., 2007. The Diatoms Biology and morphology of the Genera, Cambridge University Pres, 747 pp.

Ryan, W.B.F., Pitmann III, W.C., Major, C.O., Shimkus, K., Moskalenko, V., Jones, G.A., Dimitrov, P., Görür, N., Sakınç, M. \& Yüce, H., 1997. An abrupt drowning of the Black Sea shelf. Marine Geology, 138: 119-126.

Schornikov, E.I., 2011. Ostracoda of the Caspian origin in the AzovBlack seas basin. Joannea Geologie \& Paläontologie 11, 180-184.

Sgarrella, F., Moncharmont-Zei, M., 1993. Benthic Foraminifera of the Gulf of Naples (Italy): systematics and autoecology: Bollettino della Società Paleontologica Italiana, 32: 145-264.

Sivaci, E.R., Dere, Ş. \& Kilinç, S., 2007. Tödürge Gölünün (Sivas) Epilitik Diatom Florasının Mevsimsel Değişimi. Ege Üniversitesi Su Ürünleri Dergisi, 24(12): 45-50.

Sivaci, E.R., Yardim, Ö., Gönülol, A., Bat, L. \& Gümüş, F., 2008. Sarıum (Sinop-Türkiye) Lagününün bentik algleri. Journal of Fisheries Sciences.com, 2(4): 592600. doi. 10.3153/jfscom.20088022.

Sivaci, R.E., Barinova, S., Solak, C.N. \& Çobanoglu, K., 2013. Ecological assessment of Great Lota Lake (Turkey) on the base of diatom communities. African Journal of Biotechnology, 12(5): 453-464. doi: 10.5897/AJB12.671.

Sorokin, V.M., 2011. Correlation of Upper Quaternary deposits and paleogeography of the Black and Caspian seas. Stratigraphy and Geological Correlation, 19 (5): 563-578.

Sperling, M., Schmiedl, G., Hemleben, Ch., Emeis, K.C., Erlenkeuser, H. \& Grootes, P.M., 2003. Black Sea impact on the formation of eastern Mediterranean sapropel S1? Evidence from the Marmara Sea. Palaeogeography, Palaeoclimatology, Palaeoecology, 190: 9-21.

Schornikov, E.I., 2011. Ostracoda of the Caspian origin in the Azov-Black seas basin. Joannea Geologie \& Paläontologie, 11: 180-184.

Stanley, D.J. \& Blanpied, C., 1980. Late Quaternary water exchange between the eastern Mediterranean and the Black Sea: Nature, 266: 537-541.

Şahiner, E., Meriç, N. \& Uygun, S., 2013. Luminescence (IRSL) dating of Yeni Rabat church in Artvin, Turkey, Radiation Physics and Chemistry, 86: 68-73.

Taş, B. \& Gönülol, A., 2007. Derbent Baraj gölü (Samsun, Türkiye)'nün planktonik algleri, Journal of Fisheries Sciences com, 1(3): 111-125.

Taviani, M., Angeletti, L., Çağatay, M.N., Gasperini, L., Polonia, A. \& Wesselingh, F.P., 2014. Sedimentary and faunal signatures of the post-glacial marine 
drowning of the Pontocaspian Gemlik "lake" (Sea of Marmara). Quaternary International, 345: 11-17.

Tolun, L., Çağatay, M., Carrigan, W., 2002. Organic geochemistry and origin of Late Glacial- Holocene sapropelic layers and associated sediments in Marmara Sea. Marine Geology, 190: 47-60.

Trojanowski, J., Trrojanowska, C. \& Antonowicz, J., 2001. Nitrogen and Phosphorus in surface microlayers of on estuarine, shallow lake (north Poland). In: Zalewski, M. \& Harper, D.M. (eds). Ecohydrology and Hydrobiology, 1(4): 457-463.

Tunoğlu, C., 1999. Recent ostracoda association in the Sea of Marmara, NW Turkey. Yerbilimleri, 21: 63-87.

Tunoğlu, C., 2002. Karadeniz'in İstanbul Boğazı çıkışı ile Zonguldak ve Amasra kıy alanlarında Güncel Ostrakod topluluğu. Yerbilimleri, 26: 27-43.

Tunoğlu, C., 2003. Systematics and biostratigraphy of the Pontian Candonidae (Ostracoda) from the Eastern Black Sea Region, Northern Turkey, Geologica Carpathica, 54 (1): 21-40.

URL-1 (MD Guiry in Guiry MD, Guiry GM (2016). Algae Base. World-wide electronic publication, National University of Ireland, Galway. http://www.algaebase.org; searched on, 07.08.2016)

URL-2 (<https//en.wikipedia.org/Wiki/Craticula>, 07. 08. 2016)

URL-3 (https://www.youtube.com/watch?v=OzozEfmWIE,_9.05.2019)

URL-4

(https://species.nbnatlas.org/species/NHMSYS002105 $8185,9.05 .2019)$

URL-5

(https://diatoms.org/species/stephanodiscus_alpinus1, 9.5.2019)

URL-6

(http://www.algaebase.org/search/species/detail/?spec ies_id=31288,09.05. 2019).

URL-7 (https://diatoms.org/species/diploneis_elliptica, 09.05.2019).

URL-8

(http://www.marinespecies.org/aphia.php?p=taxdetail s\&id=163658, 11.11.2019).

URL-9

(http://www.marinespecies.org/aphia.php?p=taxdetail s\&id=172298, 15.11.2019).

URL-10

(https://www.itis.gov/servlet/SingleRpt/SingleRpt?sea rch_topic $=$ TSN\&search_value $=4580 \#$ null, 16.11.2019).

URL-11

(https://www.algaebase.org/search/species/detail/?spe cies_id=32182).

Ünlüata, Ü., Oğuz, T., Latif, M. \& Özsoy, E., 1990. On the pyscial oceanography of the Turkish straits. In: Pratt, L.J. (ed) The Physcial Oceanography of Sea Straits. NATO/ASI series, Kluwer, Dordrecht, pp. 25-60

Van Morkhoven, F.P.C.M., 1963. Post Palaeozoic Ostracoda. Elsevier Amsterdam 2: 478 pp.
Van Dam, H., Mertens, A. \& Sinkeldam, J., 1994. A coded checklist and ecological indicator values of freshwater diatoms from The Netherlands. Netherlands Journal of Aquatic Ecology, 28: 117-133.

Vardar, D., Öztürk, K., Yaltırak, C. \& Alpar, B. \& Tur, H., 2014. Late Pleistocene-Holocene evolution of the southern Marmara shelf and sub-basins: middle strand of the North Anatolian fault, southern Marmara Sea, Turkey. Marine Geophysical Research, 35: 69-85. http://dx.doi.org/10.1007/s11001-013-9210-8

Varol, M. \& Şen, B., 2014. Dicle Nehri'nin planktonik alg floras1. Journal of Fisheries Sciences.com, 8 (4): 252264.

Vidal, L., Ménot, G., Joly, C., Bruneton, H., Rostek, F., Çağatay, M.N., Major, C. \& Bard, E., 2010. Hydrology in the Sea of Marmara during the last $23 \mathrm{ka}$ : Implications for timing of Black Sea connections and sapropel deposition. Paleoceanography and Paleoclimatology, 25 (1): 1-16.

Wetzel, R.G. 1983. Limnology, Edititon Saunders College Publishing Michigan State University. 767 pp.

Williams, L.R., Hiscott, R.N., Aksu, A.E., Bradley, L.R., Horne, D.J., Stoica, M. 2018. Holocene paleoecology and paleoceanography of the southwestern Black Sea shelf revealed by ostracod assemblages. Marine Micropaleontology, 142: 48-66.

Yaltırak, C., Sakınç, M., Aksu, A.E., Hiscott, R.N., Galleb, B. \& Ülgen, U.B., 2002. Late Pleistocene uplift history along the southwestern Marmara Sea determined from raised coastal deposits and global sea-level variations. Marine Geology, 190: 283-305.

Yanina, T.A., 2014. The Ponto-Caspian region: Environmental consequences of climate change during the Late Pleistocene. Quaternary International, 345: 88-99.

Yanko, V., 1989. Quaternary Foraminifera of the PontianCaspian Region (Their Classification, Ecology, Biostratigraphy, History): $\mathrm{PhD}$, Moscow University, $924 \mathrm{pp}$.

Yanko, V. \& Troitskaja, T.S., 1987. Late Quaternary Foraminifera of the Black Sea: Moscow, Nauca, 111 pp.

Yassini, I., 1979. The littoral system ostracodes from the Bay of bou, ismail, Algeries, Algeria: Revista Espanola de micropaleontologica, XI (3): 353-416.

Zaim, E., 2007. Planktonic Diatom (Bacillariophyta) Composition of Lake Kaz (Pazar, Tokat). Turkish Journal of Biology, 31 (4): 203-224.

Zangger, E. \& Malz, H., 1989. Late Pleistocene, Holocene, and Recent ostracods from the Gulf of Argos, Greece. Courier Forschungsinstitut Senckenberg, 113: 159175 .

Zenina, M.A., Ivanova, E.V., Bradley, L.R., Murdmaa, I.O., Schornikov, E.I. \& Marret, F., 2017. Origin, migration pathways, and paleoenvironmental significance of Holocene ostracod records from the northeastern Black Sea shelf. Quaternary Research, 87: 49-65. 
Appendix 1. Benthic foraminiferal assemblage identified in the studied drillings

\begin{tabular}{|c|c|c|c|c|c|c|c|}
\hline \multirow{2}{*}{$\begin{array}{c}\text { FORAMINIFERA / LOCATIONS } \\
\text { Species / Dillings }\end{array}$} & \multicolumn{4}{|c|}{ DİLOVASI } & \multicolumn{3}{|c|}{ HERSEK B. } \\
\hline & 201 & 203 & 204 & 205 & 206 & 207 & 208 \\
\hline Adelosina bicornis (Walker \& Jacob) & & & & & $\mathrm{X}$ & & \\
\hline Adelosina carinatastriata (Wiesner) & & & & & & $\mathrm{X}$ & $\mathrm{X}$ \\
\hline Adelosina mediterranensis (Le Calvez J. \& Y.) & $\mathrm{X}$ & & & & & & $\mathrm{X}$ \\
\hline Affinetrina planciana (d'Orbigny) & & & & & $\mathrm{X}$ & & \\
\hline Ammodiscus planorbis Höglund & & & & & & $\mathrm{X}$ & $\mathrm{X}$ \\
\hline Ammonia compacta (Hofker) & $\mathrm{X}$ & & $\mathrm{X}$ & $\mathrm{X}$ & $\mathrm{X}$ & $\mathrm{X}$ & $\mathrm{X}$ \\
\hline Ammonia parkinsoniana (d'Orbigny) & $\mathrm{X}$ & & $\mathrm{X}$ & $\mathrm{X}$ & $\mathrm{X}$ & $\mathrm{X}$ & $\mathrm{X}$ \\
\hline Ammonia tepida (Cushman) & $\mathrm{X}$ & $\mathrm{X}$ & $\mathrm{X}$ & $\mathrm{X}$ & $\mathrm{X}$ & $\mathrm{X}$ & $\mathrm{X}$ \\
\hline Ammoscalaria runiana (Heron-Allen \& Earland) & & & & & & & $\mathrm{X}$ \\
\hline Amphicoryna scalaris (Batsch) & & & & & $\mathrm{X}$ & $\mathrm{X}$ & \\
\hline Astacolus crepidulus (Fichtel \& Moll) & & & & & $\mathrm{X}$ & & \\
\hline Asterigerinata mamilla (Williamson) & $\mathrm{X}$ & & $\mathrm{X}$ & $\mathrm{X}$ & $\mathrm{X}$ & $\mathrm{X}$ & $\mathrm{X}$ \\
\hline Astrononion stelligerum (d'Orbigny) & & & & $\mathrm{X}$ & & $\mathrm{X}$ & $\mathrm{X}$ \\
\hline Aubignyna perlucida (Heron-Allen \& Earland) & $\mathrm{X}$ & & $\mathrm{X}$ & $\mathrm{X}$ & $\mathrm{X}$ & $\mathrm{X}$ & $\mathrm{X}$ \\
\hline Biloculinella labiata (Schlumberger) & & & $\mathrm{X}$ & & & & \\
\hline Bolivina alata (Seguenza) & & & & & $\mathrm{X}$ & $\mathrm{X}$ & \\
\hline Bolivina dilatata (Reuss) & $\mathrm{X}$ & & $\mathrm{X}$ & $\mathrm{X}$ & $\mathrm{X}$ & $\mathrm{X}$ & $\mathrm{X}$ \\
\hline Bolivina ordinaria Phleger \& Parker & $\mathrm{X}$ & & $\mathrm{X}$ & $\mathrm{X}$ & $\mathrm{X}$ & $\mathrm{X}$ & $\mathrm{X}$ \\
\hline Bolivina pseudoplicata Heron-Allen \& Earland & & & & & $\mathrm{X}$ & & $\mathrm{X}$ \\
\hline Bolivina spathulata (Williamson) & $\mathrm{X}$ & & $\mathrm{X}$ & $\mathrm{X}$ & $\mathrm{X}$ & $\mathrm{X}$ & $\mathrm{X}$ \\
\hline Bolivina striatula Cushman & $\mathrm{X}$ & & $\mathrm{X}$ & $\mathrm{X}$ & $\mathrm{X}$ & $\mathrm{X}$ & $\mathrm{X}$ \\
\hline Bolivina subreticulata Parr & & & $\mathrm{X}$ & & & & \\
\hline Bulimina aculeata d'Orbigny & $\mathrm{X}$ & & $\mathrm{X}$ & $\mathrm{X}$ & $\mathrm{X}$ & $\mathrm{X}$ & $\mathrm{X}$ \\
\hline Bulimina elongata d'Orbigny & $\mathrm{X}$ & & $\mathrm{X}$ & $\mathrm{X}$ & $\mathrm{X}$ & $\mathrm{X}$ & $\mathrm{X}$ \\
\hline Bulimina marginata d'Orbigny & $\mathrm{X}$ & & & $\mathrm{X}$ & $\mathrm{X}$ & $\mathrm{X}$ & $\mathrm{X}$ \\
\hline Cassidulina carinata Silvestri & $\mathrm{X}$ & & $\mathrm{X}$ & $\mathrm{X}$ & $\mathrm{X}$ & $\mathrm{X}$ & $\mathrm{X}$ \\
\hline Cibicides advenum (d'Orbigny) & & & & $\mathrm{X}$ & $\mathrm{X}$ & $\mathrm{X}$ & $\mathrm{X}$ \\
\hline Cibicides floridanus (Cushman) & & & & & & & $\mathrm{X}$ \\
\hline Cibicides refulgens Montfort & & & & & & & $\mathrm{X}$ \\
\hline Cibicidoides lobatulus (Walker \& Jacob) & $\mathrm{X}$ & & $\mathrm{X}$ & $\mathrm{X}$ & $\mathrm{X}$ & $\mathrm{X}$ & $\mathrm{X}$ \\
\hline Cribroelphidium gerthi (Van Voorthuysen) & $\mathrm{X}$ & & $\mathrm{X}$ & $\mathrm{X}$ & $\mathrm{X}$ & $\mathrm{X}$ & $\mathrm{X}$ \\
\hline Cribroelphidium incertum Williamson & & & & & $\mathrm{X}$ & & \\
\hline Cribroelphidium poeyanum (d'Orbigny) & $\mathrm{X}$ & & $\mathrm{X}$ & $\mathrm{X}$ & $\mathrm{X}$ & $\mathrm{X}$ & $\mathrm{X}$ \\
\hline Cribrostomoides jeffreysii (Williamson) & & & & & & $\mathrm{X}$ & \\
\hline Cycloforina contorta (d'Orbigny) & $\mathrm{X}$ & & $\mathrm{X}$ & & $\mathrm{X}$ & $\mathrm{X}$ & $\mathrm{X}$ \\
\hline Cycloforina tenuicollis (Wiesner) & $\mathrm{X}$ & & & & & $\mathrm{X}$ & $\mathrm{X}$ \\
\hline Cycloforina villafranca (Le Calvez J. \& Y.) & & & & & & & $\mathrm{X}$ \\
\hline Discorbinella bertheloti (d'Orbigny) & $\mathrm{X}$ & & $\mathrm{X}$ & $\mathrm{X}$ & $\mathrm{X}$ & $\mathrm{X}$ & $\mathrm{X}$ \\
\hline Discorbis vilardeboana (d'Orbigny) & & & & $\mathrm{X}$ & $\mathrm{X}$ & $\mathrm{X}$ & $\mathrm{X}$ \\
\hline Eggerelloides scaber (Williamson) & & & & & & & $\mathrm{X}$ \\
\hline Elphidium aculeatum (d'Orbigny) & & & $X$ & $X$ & $X$ & $\mathrm{X}$ & $\mathrm{X}$ \\
\hline Elphidium advenum (Cushman) & & & & & $\mathrm{X}$ & & $\mathrm{X}$ \\
\hline
\end{tabular}




\begin{tabular}{|c|c|c|c|c|c|c|c|}
\hline Elphidium complanatum (d'Orbigny) & $\mathrm{X}$ & & $\mathrm{X}$ & $\mathrm{X}$ & $\mathrm{X}$ & $\mathrm{X}$ & $\mathrm{X}$ \\
\hline Elphidium crispum (Linnaeus) & $\mathrm{X}$ & & $\mathrm{X}$ & $\mathrm{X}$ & $\mathrm{X}$ & $\mathrm{X}$ & $\mathrm{X}$ \\
\hline Elphidium macellum (Fichtel \& Moll) & $\mathrm{X}$ & & $\mathrm{X}$ & $\mathrm{X}$ & $\mathrm{X}$ & $\mathrm{X}$ & $\mathrm{X}$ \\
\hline Elphidium margaritaceum Cushman & $\mathrm{X}$ & & & & & & \\
\hline Elphidium pulvereum Todd & & & & $\mathrm{X}$ & $\mathrm{X}$ & $\mathrm{X}$ & $\mathrm{X}$ \\
\hline Elphidium punctatum (Terquem) & $\mathrm{X}$ & & & & $\mathrm{X}$ & $\mathrm{X}$ & $\mathrm{X}$ \\
\hline Eponides concameratus (Montagu) & & & $\mathrm{X}$ & & $\mathrm{X}$ & & $\mathrm{X}$ \\
\hline Favulina hexagona (Williamson) & & & & & $\mathrm{X}$ & & \\
\hline Fissurina staphyllearia Schwager & & & & & $\mathrm{X}$ & & \\
\hline Fursenkoina subacuta (d'Orbigny) & $\mathrm{X}$ & & & & $\mathrm{X}$ & $\mathrm{X}$ & $\mathrm{X}$ \\
\hline Fursenkoina complanata (Egger) & $\mathrm{X}$ & & $\mathrm{X}$ & $\mathrm{X}$ & $\mathrm{X}$ & $\mathrm{X}$ & $\mathrm{X}$ \\
\hline Gavelinopsis praegeri (Heron-Allen \& Earland) & $\mathrm{X}$ & & $\mathrm{X}$ & $\mathrm{X}$ & $\mathrm{X}$ & $\mathrm{X}$ & $\mathrm{X}$ \\
\hline Globobulimina affinis (d'Orbigny) & $\mathrm{X}$ & & $\mathrm{X}$ & & $\mathrm{X}$ & & $\mathrm{X}$ \\
\hline Globocassidulina crassa (d'Orbigny) & $\mathrm{X}$ & & & $\mathrm{X}$ & $\mathrm{X}$ & $\mathrm{X}$ & $\mathrm{X}$ \\
\hline Globocassidulina minuta (Cushman) & & & & & & & $\mathrm{X}$ \\
\hline Globocassidulina subglobosa (Brady) & $\mathrm{X}$ & & $\mathrm{X}$ & $\mathrm{X}$ & $\mathrm{X}$ & $\mathrm{X}$ & \\
\hline Gyroidina umbonata (Silvestri) & $\mathrm{X}$ & & & & $\mathrm{X}$ & & $\mathrm{X}$ \\
\hline Haynesina anglica (Murray) & & & & & & $\mathrm{X}$ & $\mathrm{X}$ \\
\hline Haynesina depressula (Walker \& Jacob) & $\mathrm{X}$ & $\mathrm{X}$ & $\mathrm{X}$ & $\mathrm{X}$ & $\mathrm{X}$ & $\mathrm{X}$ & $\mathrm{X}$ \\
\hline Hyalinea balthica (Schröter) & & & & & $\mathrm{X}$ & & \\
\hline Lachanella undulata (d'Orbigny) & & & & & & $\mathrm{X}$ & $\mathrm{X}$ \\
\hline Lagena semistriata Williamson & & & & & & & $\mathrm{X}$ \\
\hline Lagena striata (d'Orbigny) & $\mathrm{X}$ & & & & $\mathrm{X}$ & $\mathrm{X}$ & $\mathrm{X}$ \\
\hline Massilina gualtieriana (d'Orbigny) & & & & & & & $\mathrm{X}$ \\
\hline Massilina secans (d'Orbigny) & & & & & & $\mathrm{X}$ & $\mathrm{X}$ \\
\hline Miliolinella elongata Kruit & & & & & $\mathrm{X}$ & & $\mathrm{X}$ \\
\hline Miliolinella subrotunda (Montagu) & $\mathrm{X}$ & & & $\mathrm{X}$ & $\mathrm{X}$ & $\mathrm{X}$ & $\mathrm{X}$ \\
\hline Neoconorbina terquemi (Rzehak) & $\mathrm{X}$ & & & $\mathrm{X}$ & $\mathrm{X}$ & $\mathrm{X}$ & $\mathrm{X}$ \\
\hline Neoeponides bradyi (Le Calvez) & $\mathrm{X}$ & & & $\mathrm{X}$ & $\mathrm{X}$ & $\mathrm{X}$ & $\mathrm{X}$ \\
\hline Nonion subturgidum (Cushman) & & & $\mathrm{X}$ & $\mathrm{X}$ & $\mathrm{X}$ & & \\
\hline Nonionella atlantica Cushman & & & & $\mathrm{X}$ & & & \\
\hline Nonionoides grateloupii (d'Orbigny) & & & & & & & $\mathrm{X}$ \\
\hline Nonionoides turgidus (Williamson) & $\mathrm{X}$ & & $\mathrm{X}$ & $\mathrm{X}$ & $\mathrm{X}$ & $\mathrm{X}$ & $\mathrm{X}$ \\
\hline Patellina corrugata Williamson & & & $\mathrm{X}$ & $\mathrm{X}$ & $\mathrm{X}$ & $\mathrm{X}$ & $\mathrm{X}$ \\
\hline Planoglabratella opercularis (d'Orbigny) & & & & & & & $\mathrm{X}$ \\
\hline Planorbulina mediterranensis d'Orbigny & $\mathrm{X}$ & & & $\mathrm{X}$ & & & \\
\hline Planulina ariminensis d'Orbigny & & & & & $\mathrm{X}$ & & \\
\hline Porosononion subgranosus (Egger) & $\mathrm{X}$ & & $\mathrm{X}$ & $\mathrm{X}$ & $\mathrm{X}$ & $\mathrm{X}$ & $\mathrm{X}$ \\
\hline Pseudotriloculina lecalvezae (Kaasschieter) & $\mathrm{X}$ & & & & & $\mathrm{X}$ & \\
\hline Pseudotrilocuina limbata (d'Orbigny) & & & & & & $\mathrm{X}$ & $\mathrm{X}$ \\
\hline Pseudotriloculina rotunda (d'Orbigny) & & & & & $\mathrm{X}$ & & $\mathrm{X}$ \\
\hline Pyrgo elongata (d'Orbigny) & $\mathrm{X}$ & & & & & & \\
\hline Quinqueloculina aglutinans d'Orbigny & & & & & $\mathrm{X}$ & & $\mathrm{X}$ \\
\hline Quinqueloculina berthelotiana d'Orbigny & $\mathrm{X}$ & & & & & $\mathrm{X}$ & $\mathrm{X}$ \\
\hline Quinqueloculina bidentata d'Orbigny & & & & $X$ & & $\mathrm{X}$ & $\mathrm{X}$ \\
\hline
\end{tabular}




\begin{tabular}{|c|c|c|c|c|c|c|c|}
\hline Quinqueloculina bosciana d'Orbigny & & & & & & $\mathrm{X}$ & $\mathrm{X}$ \\
\hline Quinqueloculina irregularis d'Orbigny & & & & & & $\mathrm{X}$ & $\mathrm{X}$ \\
\hline Quinqueloculina laevigata d'Orbigny & $\mathrm{X}$ & & $\mathrm{X}$ & $\mathrm{X}$ & $\mathrm{X}$ & $\mathrm{X}$ & $\mathrm{X}$ \\
\hline Quinqueloculina lamarckiana d'Orbigny & $\mathrm{X}$ & & & & & & \\
\hline Quinqueloculina parvula Schlumberger & & & & $\mathrm{X}$ & & $\mathrm{X}$ & \\
\hline Quinqueloculina schlumbergeri (Wiesner) & $\mathrm{X}$ & & & $\mathrm{X}$ & & $\mathrm{X}$ & $\mathrm{X}$ \\
\hline Quinqueloculina seminula (Linnaeus) & $\mathrm{X}$ & & $\mathrm{X}$ & $\mathrm{X}$ & $\mathrm{X}$ & $\mathrm{X}$ & $\mathrm{X}$ \\
\hline Quinqueloculina stalkeri Loeblich \& Tappan & $\mathrm{X}$ & & & $\mathrm{X}$ & $\mathrm{X}$ & $\mathrm{X}$ & $\mathrm{X}$ \\
\hline Rectuvigerina phlegeri Le Calvez & $\mathrm{X}$ & & & $\mathrm{X}$ & $\mathrm{X}$ & & \\
\hline Reussella spinulosa (Reuss) & $\mathrm{X}$ & & & & & & \\
\hline Rosalina bradyi (Cushman) & $\mathrm{X}$ & & $\mathrm{X}$ & $\mathrm{X}$ & $\mathrm{X}$ & $\mathrm{X}$ & $\mathrm{X}$ \\
\hline Rosalina floridensis (Cushman) & $\mathrm{X}$ & & & & & $\mathrm{X}$ & $\mathrm{X}$ \\
\hline Rosalina globularis d'Orbigny & & & & & & & $\mathrm{X}$ \\
\hline Rosalina macropora (Hofker) & $\mathrm{X}$ & & & & & & $\mathrm{X}$ \\
\hline Sahulia conica (d'Orbigny) & $\mathrm{X}$ & & & $\mathrm{X}$ & & & $\mathrm{X}$ \\
\hline Sigmoilina costata Schlumberger & $\mathrm{X}$ & & & & $\mathrm{X}$ & $\mathrm{X}$ & $\mathrm{X}$ \\
\hline Sigmoilina distorta Phleger \& Parker & & & & & & $\mathrm{X}$ & \\
\hline Sigmoilopsis schlumbergeri (Silvestri) & $X$ & & & & & & \\
\hline Siphonaperta aspera (d'Orbigny) & & & & & & $\mathrm{X}$ & $\mathrm{X}$ \\
\hline Siphonaperta dilatata (Le Calvez J. \& Y.) & & & & & & $\mathrm{X}$ & $\mathrm{X}$ \\
\hline Sphaerogypsina globulus (Reuss) & & & & $\mathrm{X}$ & & & \\
\hline Spirillina vivipara Ehrenberg & & & & $\mathrm{X}$ & & $\mathrm{X}$ & $\mathrm{X}$ \\
\hline Spiroloculina depressa d'Orbigny & & & & & & & $\mathrm{X}$ \\
\hline Spiroloculina excavata d'Orbigny & $\mathrm{X}$ & & $\mathrm{X}$ & $\mathrm{X}$ & $\mathrm{X}$ & & $\mathrm{X}$ \\
\hline Spirophthalmidium tenuiseptatum (Brady) & $\mathrm{X}$ & & & & & & \\
\hline Spiroplectinella wrighti (Silvestri) & $\mathrm{X}$ & & & $\mathrm{X}$ & $\mathrm{X}$ & & $\mathrm{X}$ \\
\hline Spirosigmoilina tenuis (Č̌jžek) & $\mathrm{X}$ & & & & $\mathrm{X}$ & $\mathrm{X}$ & $\mathrm{X}$ \\
\hline Stomatorbina concentrica (Parker \&Jones) & & & & $\mathrm{X}$ & & $\mathrm{X}$ & \\
\hline Textularia aglutinans d'Orbigny & $\mathrm{X}$ & & & $\mathrm{X}$ & & $\mathrm{X}$ & $\mathrm{X}$ \\
\hline Textularia bocki Höglund & $\mathrm{X}$ & & & & & & $\mathrm{X}$ \\
\hline Textularia calva Lalicker & $\mathrm{X}$ & & & $\mathrm{X}$ & $\mathrm{X}$ & $\mathrm{X}$ & $\mathrm{X}$ \\
\hline Textularia pala Czjzek & $\mathrm{X}$ & & & $\mathrm{X}$ & $\mathrm{X}$ & $\mathrm{X}$ & $\mathrm{X}$ \\
\hline Textularia sagittula Defrance & $\mathrm{X}$ & & $\mathrm{X}$ & $\mathrm{X}$ & & & $\mathrm{X}$ \\
\hline Trifarina angulosa (Williamson) & $\mathrm{X}$ & & & & & & \\
\hline Triloculina adriatica Le Calvez J. \& Y. & & & & & & & $\mathrm{X}$ \\
\hline Triloculina marioni Schlumberger & & & & & $\mathrm{X}$ & $\mathrm{X}$ & $\mathrm{X}$ \\
\hline Triloculina oblonga (Montagu) & $X$ & & & & & $\mathrm{X}$ & $\mathrm{X}$ \\
\hline Triloculina plicata Terquem & $\mathrm{X}$ & & & $\mathrm{X}$ & & $\mathrm{X}$ & $\mathrm{X}$ \\
\hline Triloculina schreiberiana d'Orbigny & & & & & & $\mathrm{X}$ & $\mathrm{X}$ \\
\hline Triloculina tricarinata d'Orbigny & & & & $\mathrm{X}$ & & & \\
\hline Valvulineria bradyana (Fornasini) & $\mathrm{X}$ & & $\mathrm{X}$ & $\mathrm{X}$ & $\mathrm{X}$ & $\mathrm{X}$ & $\mathrm{X}$ \\
\hline TOTAL: 75 genera & 41 & 1 & 27 & 38 & 45 & 43 & 49 \\
\hline TOTAL: 128 species & 69 & 2 & 39 & 60 & 71 & 77 & 97 \\
\hline
\end{tabular}

